


\section{Verdeling van de toeslagen van de eerste pijler van het GLB over landbouwbedrijven in de EU}

Ida Terluin en David Verhoog

Dit onderzoek is uitgevoerd door Wageningen Economic Research in opdracht van en gefinancierd door het ministerie van Landbouw, Natuur en Voedselkwaliteit, in het kader van het Beleidsondersteunend onderzoeksthema 'GLB' (projectnummer BO-20-017-044-LEI)

Wageningen Economic Research

Wageningen, maart 2018

RAPPORT

2018-039

ISBN 978-94-6343-841-4 
Terluin, I.J. en A.D. Verhoog, 2018. Verdeling van de toeslagen van de eerste pijler van het GLB over landbouwbedrijven in de EU. Wageningen, Wageningen Economic Research, Rapport 2018-039.

62 blz.; 9 fig.; 4 tab.; 9 ref.

In deze studie is een analyse gemaakt van de verdeling van de toeslagen van de eerste pijler van het Gemeenschappelijk landbouwbeleid over landbouwbedrijven in de EU28. Deze verdeling laat een onevenwichtig beeld zien: in 2015 ontving $81 \%$ van de EU-boeren $20 \%$ van de toeslagen.

Landbouwbedrijven die weinig toeslagen ontvangen hebben doorgaans minder hectares dan bedrijven die veel toeslagen ontvangen. De onevenwichtige verdeling van toeslagen ontstaat doordat de groep boeren met weinig hectares in de EU28 veel groter is dan de groep met veel hectares.

Dit rapport is gratis te downloaden op https://doi.org/10.18174/444117 of op www. wur. nl/economicresearch (onder Wageningen Economic Research publicaties).

\section{(C) 2018 Wageningen Economic Research}

Postbus 29703, 2502 LS Den Haag, T 07033583 30, E communications.ssg@wur.nl, www.wur.nl/economic-research. Wageningen Economic Research is onderdeel van Wageningen University \& Research.

\section{(cc) BY-NC}

Wageningen Economic Research hanteert voor haar rapporten een Creative Commons Naamsvermelding 3.0 Nederland licentie.

(c) Wageningen Economic Research, onderdeel van Stichting Wageningen Research, 2018 De gebruiker mag het werk kopiëren, verspreiden en doorgeven en afgeleide werken maken. Materiaal van derden waarvan in het werk gebruik is gemaakt en waarop intellectuele eigendomsrechten berusten, mogen niet zonder voorafgaande toestemming van derden gebruikt worden. De gebruiker dient bij het werk de door de maker of de licentiegever aangegeven naam te vermelden, maar niet zodanig dat de indruk gewekt wordt dat zij daarmee instemmen met het werk van de gebruiker of het gebruik van het werk. De gebruiker mag het werk niet voor commerciële doeleinden gebruiken.

Wageningen Economic Research aanvaardt geen aansprakelijkheid voor eventuele schade voortvloeiend uit het gebruik van de resultaten van dit onderzoek of de toepassing van de adviezen.

Wageningen Economic Research is ISO 9001:2008 gecertificeerd.

Wageningen Economic Research Rapport 2018-039 | Projectcode 2282500250

Foto omslag: Shutterstock 


\section{Inhoud}

Woord vooraf $\quad 5$

Samenvatting $\quad 6$

S.1 In 2015 ontving 81\% van de boeren in de EU28 20\% van de inkomenstoeslagen. De groep boeren die $20 \%$ van de inkomenstoeslagen ontving varieerde van $54 \%$ in Luxemburg tot $93 \%$ in Slowakije

S.2 Meeste boeren ontvangen minder dan $€ 5.000$ aan toeslagen $\quad 7$

$\begin{array}{lll}\text { S.3 Onderzoeksopzet } & 7\end{array}$

1

$\begin{array}{lc}\text { Inleiding } & 8\end{array}$

2

$\begin{array}{ll}\text { Aanpak } & 9\end{array}$

3

Resultaten

3.1 Inleiding 11

3.2 Verdeling van toeslagen over boeren naar omvang toeslagen 11

3.3 Verdeling van toeslagen over boeren naar economische grootteklasse bedrijven 18

3.4 Aandeel van de inkomenstoeslag in het landbouwinkomen per bedrijfstype $\quad 19$

4

Conclusies

22

Literatuur en websites

Bijlage 1 Fictieve verdeling van de toeslagen op basis van een uniforme hectarepremie over bedrijven in de EU-lidstaten

Bijlage 2 I nkomenstoeslagen uit de eerste pijler van het GLB in het inkomen per bedrijfstype in de EU-lidstaten, 2015 



\section{Woord vooraf}

De Europese Commissie heeft in haar mededeling 'De toekomst van voeding en landbouw' ( $\operatorname{COM(2017)~} 713$ def) de contouren geschetst van de invulling van het Gemeenschappelijk landbouwbeleid (GLB) na 2020. De Europese Commissie stelt in die mededeling dat zij rechtstreekse betalingen aan boeren als een essentieel onderdeel beschouwt. Die betalingen dienen om de kloof tussen de landbouwinkomens en de inkomens in andere economische sectoren gedeeltelijk te overbruggen. Op die manier vormen ze een belangrijk inkomensvangnet, dat eraan bijdraagt dat boeren overal in de EU landbouwactiviteiten kunnen verrichten, ook in gebieden met natuurlijke beperkingen. Het belang dat in de EU wordt gehecht aan het bevorderen van redelijke inkomens in de landbouw is ook vastgelegd in het Verdrag van Lissabon.

Elk jaar publiceert de Europese Commissie een verslag van de verdeling van de rechtstreekse betalingen van de eerste pijler van het GLB over boeren in de EU. Daaruit blijkt dat de verdeling een onevenwichtig beeld laat zien: zo'n $80 \%$ van de boeren ontvangt zo'n $20 \%$ van de toeslagen. Dat betekent dat de overige $20 \%$ van de boeren een fors aandeel ontvangt: $80 \%$ van de toeslagen. De onevenwichtige verdeling roept de vraag op of de toeslagen volgens de huidige werkwijze terechtkomen bij die bedrijven waar ze nodig zijn om een redelijk inkomen uit de landbouw te behalen. Voor een goede onderbouwing van standpunten in de EU-brede discussie over de toekomst van de inkomenstoeslagen in de eerste pijler van het GLB heeft het ministerie van Landbouw, Natuur en Voedselkwaliteit behoefte aan inzicht in de verdeling van de huidige toeslagen van de eerste pijler van het GLB over landbouwbedrijven in de EU-lidstaten. Daarom heeft het ministerie van Landbouw, Natuur en Voedselkwaliteit opdracht aan Wageningen Economic Research gegeven om een analyse te maken van de verdeling van de toeslagen over landbouwbedrijven in de EU28 in 2015 - het jaar waarvoor de meest recente data beschikbaar zijn - en na te gaan welke verschillen daarin tussen lidstaten bestaan en wat de structuurkenmerken zijn van landbouwbedrijven die veel/weinig toeslagen ontvangen.

De studie is uitgevoerd door dr. I.J. Terluin (projectleider) en drs. A.D. Verhoog van Wageningen Economic Research. Wageningen Economic Research bedankt de volgende personen van het ministerie van Landbouw, Natuur en Voedselkwaliteit voor hun ondersteuning en samenwerking: dr. R.P. Baayen, dr. J.L.M. Boogerd, ir. J.W.J. van Esch, drs. L.J.T.C. Lantain, ir. H.J.A. Ruissen en ir. F. Vroegop.

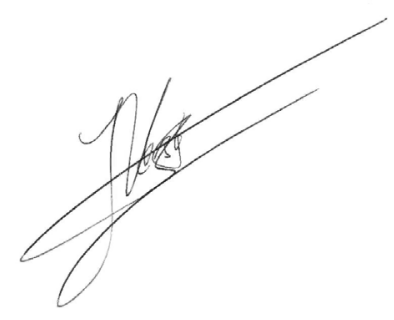

Prof.dr.ir. J.G.A.J. (J ack) van der Vorst Algemeen Directeur Social Sciences Group (SSG)

Wageningen University \& Research 


\section{Samenvatting}

\section{S.1 In 2015 ontving 81\% van de boeren in de EU28 20\% van de inkomenstoeslagen. De groep boeren die $20 \%$ van de inkomenstoeslagen ontving varieerde van $54 \%$ in Luxemburg tot $93 \%$ in Slowakije}

De verdeling van de inkomenstoeslagen van de eerste pijler van het GLB laat een onevenwichtig beeld zien: in 2015 (het jaar waarvoor de meest recente data beschikbaar zijn) ontving $81 \%$ van de boeren in de EU28 20\% van de inkomenstoeslagen. Er is dus een grote groep boeren in de EU28 die betrekkelijk weinig toeslagen ontvangt en een kleine groep boeren die betrekkelijk veel toeslagen krijgt. De omvang van de groep boeren die $20 \%$ van de inkomenstoeslagen ontvangt loopt nogal uiteen tussen de lidstaten: hij is relatief het kleinst (54\%) in Luxemburg en het grootst (93\%) in Slowakije (figuur S.1). Daarmee is de verdeling in Luxemburg minder ongelijk dan het EU28gemiddelde, terwijl er in Slowakije juist een meer ongelijke verdeling is. Ook in Nederland is de verdeling minder ongelijk dan het EU28-gemiddelde: in 2015 ontving 56\% van de boeren in ons land $20 \%$ van de toeslagen. Zie paragraaf 3.2 .

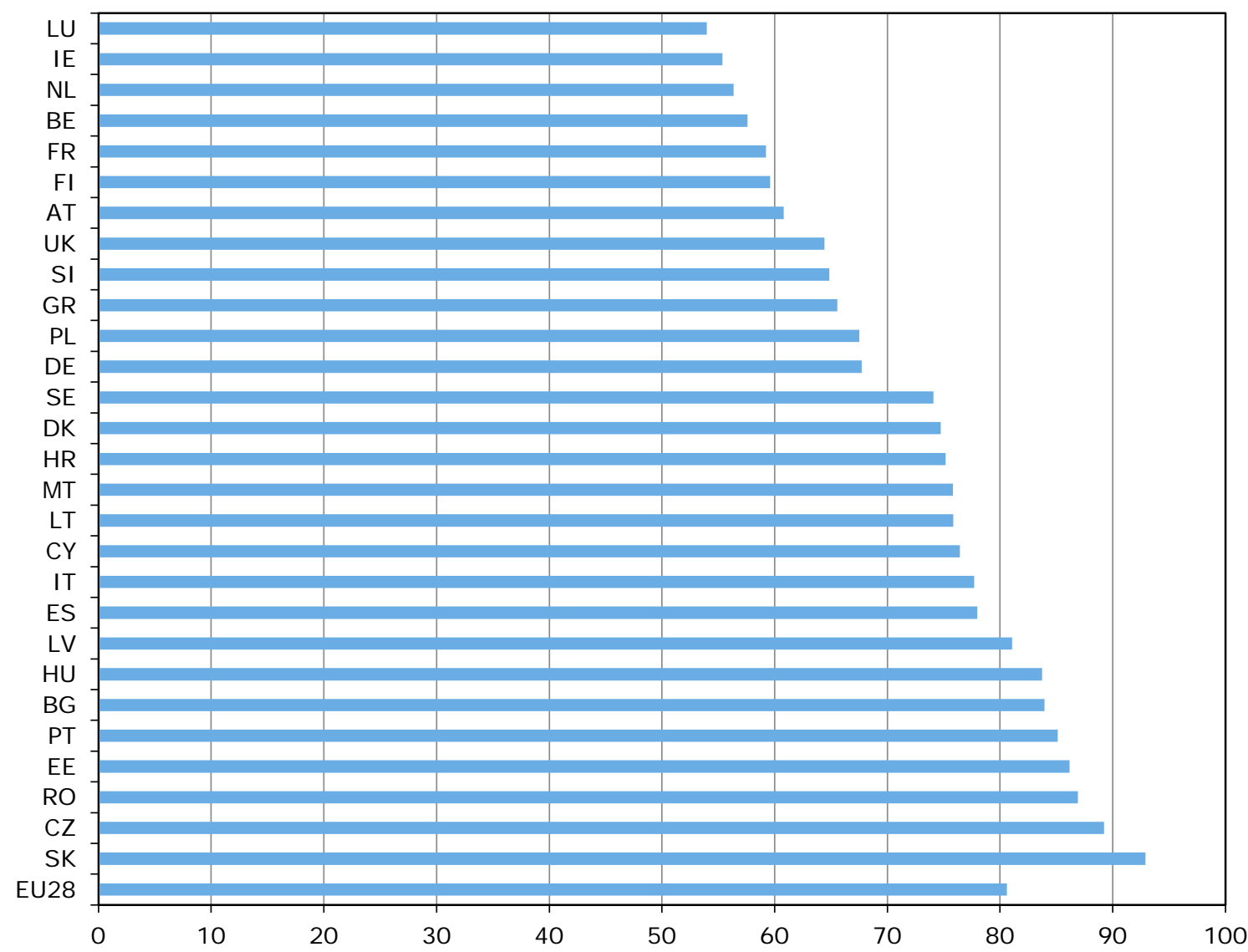

Figuur S.1 Aandeel boeren in elke EU-lidstaat dat 20\% van de inkomenstoeslagen van de eerste pijler van het GLB ontvangt, 2015 (\% van totaal aantal boeren) Bron: EC (2017b); bewerking Wageningen Economic Research. 


\section{Onevenwichtige verdeling van de toeslagen hangt voor deel samen met landspecifieke}

elementen en met verschil in bedrijfsgrootte

De inkomenstoeslagen zijn deels gebaseerd op het aantal hectares per landbouwbedrijf en deels op landspecifieke elementen zoals historische referenties en gekoppelde betalingen. Zolang het GLB lidstaten verschillende opties voor de wijze van toekennen van de toeslagen biedt, zijn wegens het toepassen van specifieke opties verschillen tussen de lidstaten in de verdeling van de toeslagen over boeren te verwachten. Maar ook in het geval dat lidstaten alleen een uniforme hectarepremie zouden mogen toekennen, resulteert een ongelijke verdeling van toeslagen over de boeren. Dan zou zo'n 86\% van de boeren in de EU28 20\% van de toeslagen ontvangen, wat een onevenwichtiger verdeling is dan de werkelijke verdeling in 2015. Deze onevenwichtige verdeling heeft te maken met het feit dat de groep boeren met weinig hectares in de EU28 veel groter is dan de groep met veel hectares. Een gelijke verdeling van toeslagen over boeren kan bij een uniforme hectarepremie pas ontstaan wanneer elk bedrijf in de EU28 evenveel hectares heeft. De huidige verspreiding van bedrijven over de grootteklassen in ha wijkt daar ver van af. Zie paragraaf 3.2.

\section{S.2 Meeste boeren ontvangen minder dan $€ 5.000$ aan toeslagen}

Zo'n drie kwart van de boeren in de EU28 ontving in 2015 minder dan $€ 5.000$ aan toeslagen. Daarbij viel een kwart van de boeren in de categorie van minder dan $€ 500$, een kwart in de categorie van tussen de $€ 500$ en $€ 1.250$, en een kwart in de categorie van tussen $€ 1.250$ en $€ 5.000$. Zo'n 16.000 boeren in de EU $(0,2 \%$ van het totaal aantal boeren) ontvingen in 2015 meer dan $€ 150.000$ aan toeslagen; in Nederland ging het om ruim 100 boeren. Zie paragraaf 3.2.

\section{Aandeel toeslagen in het landbouwinkomen loopt sterk uiteen}

Het aandeel van de toeslagen in het gezinsinkomen uit bedrijf per gezinsarbeidskracht in de EU28 is aanzienlijk en varieert van een derde bij de lagere inkomensklassen tot de helft in de hogere inkomensklassen. Naarmate het inkomen uit bedrijf hoger wordt, ontvangen boeren dus gemiddeld een hogere inkomenstoeslag. Het aandeel van de toeslagen in het inkomen van de verschillende bedrijfstypen varieert nogal rond het EU-gemiddelde: in $2015 \mathrm{kwam}$ het aandeel van de toeslag in het gezinsinkomen uit bedrijf per gezinsarbeidskracht op de vleeskoeienbedrijven en bedrijven met granen, oliezaden en eiwitgewassen boven de 100\% uit, lag het aandeel op de overige akkerbouwbedrijven, melkveebedrijven, en schapen- en geitenbedrijven rond $70 \%$, en beliep het aandeel op de intensieve veehouderijbedrijven zo'n 30\%. Omdat de landbouwinkomens van jaar tot jaar nogal kunnen fluctueren, kunnen de aandelen van de toeslagen in het landbouwinkomen van jaar tot jaar wat verschillen van elkaar. Zie paragraaf 3.4.

\section{S.3 Onderzoeksopzet}

In het kader van de eerste pijler van het GLB ontvangen boeren inkomenstoeslagen. Deze zijn bedoeld om te zorgen voor redelijke inkomens in de landbouw. In deze studie is nagegaan hoe de inkomenstoeslagen in 2015 over de landbouwbedrijven in de EU zijn verdeeld en welke verschillen zich daarbij tussen de lidstaten voordoen. Zie hoofdstuk 1.

De studie is gebaseerd op berekeningen met data uit drie bronnen: data van de Europese Commissie (EC) over het aantal ontvangers van toeslagen van de eerste pijler, het Farm Accountancy Data Network (FADN) en de Farm Structure Survey (FSS). Zie hoofdstuk 2. 


\section{$1 \quad$ Inleiding}

In de discussie over de modernisering en vereenvoudiging van het Gemeenschappelijk landbouwbeleid (GLB) speelt de ondersteuning van gezinsbedrijven op het platteland een belangrijke rol. Het Verdrag van Lissabon (Art. 39) bindt de EU en de lidstaten om te zorgen voor een redelijk inkomen voor landbouwers, om zo de kloof tussen de landbouwinkomens en de inkomens in andere economische sectoren gedeeltelijk te overbruggen. In de beginperiode van het GLB werd dit vooral gedaan met prijsondersteuning. Vanaf de jaren negentig werd de prijsondersteuning geleidelijk aan vervangen door inkomenstoeslagen. In de periode 2014-2020 worden redelijke inkomens voor landbouwers in het GLB nagestreefd met toeslagen per hectare en gekoppelde betalingen aan bepaalde producten. Deze toeslagen en gekoppelde betalingen lopen via de eerste pijler van het GLB.

In de EU-brede discussie over de toekomst van de GLB-inkomenssteun staan gezinsbedrijven centraal als beoogde doelgroep. De vraag is of de toeslagen daar in de praktijk terechtkomen, want de verdeling van eerstepijlertoeslagen over landbouwbedrijven vertoont een onevenwichtig beeld (EC, 2016 en 2017b; Matthews, 2016): 20\% van de bedrijven in de EU28 ontvangt circa 80\% van de toeslagen. Omdat de toeslagen deels zijn gebaseerd op het aantal hectares per bedrijf, krijgen bedrijven met veel hectares meer toeslagen dan bedrijven met weinig hectares. Dat leidt per definitie tot een ongelijke verdeling van toeslagen over bedrijven. Een ander bezwaar tegen de huidige vorm van toeslagen is dat deze neerslaan in de grondprijs. Doordat een deel van de grondeigenaren niet afkomstig is uit de landbouwsector, leidt dit tot een uitstroom van kapitaal uit de landbouwsector.

De onevenwichtige verdeling roept de vraag op of de toeslagen volgens de huidige werkwijze terechtkomen bij die bedrijven waar ze nodig zijn om een redelijk inkomen uit de landbouw te behalen. Voor een goede onderbouwing van standpunten in de EU-brede discussie over de toekomst van de inkomenstoeslagen in de eerste pijler van het GLB heeft het ministerie van Landbouw, Natuur en Voedselkwaliteit behoefte aan inzicht in de verdeling van de huidige toeslagen van de eerste pijler van het GLB over landbouwbedrijven in de EU-lidstaten en verschillen in de verdeling tussen lidstaten.

\section{Onderzoeksvragen}

In deze studie staan de volgende vragen centraal:

- Hoe zijn de toeslagen uit de eerste pijler van het GLB in 2015 over de bedrijven per EU-lidstaat verdeeld en welke verschillen bestaan daarin tussen landen?

- Hoe komt het dat er verschillen in de verdeling van de toeslagen tussen lidstaten bestaan?

- Wat zijn de structuurkenmerken van bedrijven die weinig/veel toeslagen ontvangen?

- Wat is het aandeel van de landbouwbedrijven in iedere lidstaat dat geheel geen toeslag ontvangt?

- Wat is het aandeel van de toeslagen in het inkomen per arbeidskracht naar grootte en type bedrijven per EU-lidstaat?

Opbouw van deze studie

De opbouw van deze studie is als volgt. In hoofdstuk 2 beschrijven we de aanpak van het onderzoek. In hoofdstuk 3 komen de resultaten aan de orde. Daarin bespreken we eerst de verdeling van de toeslagen over boeren naar omvang van de ontvangen toeslagen en naar economische grootteklasse van de bedrijven. Daarna besteden we aandacht aan het aandeel van de inkomenstoeslag in het landbouwinkomen. In het laatste hoofdstuk trekken we enkele conclusies. 


\section{Aanpak}

Voor de aanpak van deze studie gaan we in op de drie databronnen die we gebruiken: data van de Europese Commissie (EC) over het aantal ontvangers van toeslagen van de eerste pijler, het Farm Accountancy Data Network (FADN) en de Farm Structure Survey (FSS). Ook geven we aan welke berekeningen we hebben uitgevoerd voor het bepalen van de verdeling van toeslagen over boeren naar economische grootteklasse van de landbouwbedrijven en de fictieve verdeling van toeslagen op basis van een uniforme hectarepremie in de EU.

EC-data: verdeling van toeslagen over boeren naar omvang toeslagen De EC publiceert jaarlijks een overzicht van het aantal ontvangers ('begunstigden') van toeslagen van de eerste pijler, waarbij ze de ontvangers indeelt naar de omvang van de ontvangen toeslagen. Daarbij wordt een indeling van 15 klassen gebruikt, oplopend van $€ 0-500$ tot groter dan $€ 500.000$. De laatst verschenen data zijn die over het financiële jaar ${ }^{1} 2016$ (EC, 2017b). Het gaat dan om de betalingen uit de eerste pijler over het kalenderjaar 2015, waarin de nieuwe aanpak van de toeslagen volgens het GLB 2014-2020 voor het eerst werd toegepast. Met behulp van de EC-data over het financiële jaar 2016 kan worden berekend welk deel van de boeren in elke lidstaat in 2015 20\% van de toeslagen ontving, hoeveel boeren geen toeslagen ontvingen en hoeveel boeren meer dan $€ 150.000$ aan toeslagen ontvingen.

FADN: verdeling van toeslagen over boeren naar economische grootteklasse bedrijven Matthews (2016) heeft een verdeling van de inkomenstoeslagen van de eerste pijler over bedrijven gemaakt, waarbij hij de bedrijven heeft ingedeeld naar economische grootteklasse. Op die manier kan een berekening worden gemaakt van het aandeel van de toeslagen in het landbouwinkomen. Omdat de EC-data geen informatie over de economische grootteklasse bevat, heeft hij de EC-data gekoppeld aan data uit het FADN. Matthews heeft zijn berekening uitgevoerd voor het kalenderjaar 2013; daarvoor heeft hij data van de inkomenstoeslagen uit het financiële jaar 2014 (EC, 2015) en FADNdata voor het boekhoudjaar 2013 gebruikt. Wij voeren dezelfde berekening uit als Matthews, maar gebruiken dan de inkomenstoeslagen uit het financiële jaar 2016 (EC, 2017b) en FADN-data voor het kalenderjaar 2015. Omdat FADN 4,7 miljoen commerciële landbouwbedrijven in de EU vertegenwoordigt en de EC (EC, 2017b) uitgaat van 6,7 miljoen ontvangers van betalingen, vergt de koppeling van beide datareeksen een aantal veronderstellingen. In navolging van Matthews (2016) bestaat onze berekening van de verdeling van de toeslagen van de eerste pijler naar economische grootteklasse in het kalenderjaar 2015 uit de volgende stappen en veronderstellingen:

1. We veronderstellen dat de 2 miljoen boeren die wel in de EC-data zitten maar niet in de FADNdata kleine bedrijven zijn, die weinig directe betalingen ontvangen. De groep boeren die volgens de EC-data minder dan $€ 500$ ontvangen (1,8 miljoen boeren) is iets kleiner dan die 2 miljoen.

2. FADN onderscheidt zes economische grootteklassen: (1) € 2.000-8.000; (2) € 8.000-25.000; (3) € 25.000-50.000; (4) €50.000-100.000; (5) € 100.000-500.000; (6) >=€ 500.000. We voegen hier een economische grootteklasse $<€ 2.000$ aan toe en veronderstellen dat hier de 1,8 miljoen boeren uit de EC-data in zitten die minder dan $€ 500$ ontvangen.

3. Voor het gemiddelde bedrijf in elk van de economische grootteklassen klassen geeft FADN informatie over de omvang van de ontvangen toeslagen uit de eerste pijler en het inkomen uit bedrijf. Het blijkt dat de inkomenstoeslag in de economische grootteklasse $€ 2.000-8.000$ ongeveer een derde van het inkomen uit bedrijf bedraagt. Deze verhouding passen we ook toe op de economische grootteklasse $<€ 2.000$.

4. Volgens de EC-data ontvangen de 1,8 miljoen boeren (die minder dan $€ 500$ ontvangen) in totaal $€ 558$ miljoen aan toeslagen. Als de toeslagen een derde van het inkomen vormen ( $\operatorname{stap} 3$ ), dan komt het totale inkomen in de economische grootteklasse $<€ 2.000$ uit op $€ 1.675$ miljoen (3* $€ 558$ miljoen). Dat komt voor elk van die 1,8 miljoen landbouwbedrijven in die klasse neer op

1 Directe betalingen voor kalenderjaar $\mathrm{N}$ worden uitbetaald in het financiële jaar $\mathrm{N}+1$. Het financiële jaar $\mathrm{N}+1$ start op 16 oktober in jaar $\mathrm{N}$ en loopt tot 15 oktober in jaar $\mathrm{N}+1$. Het financiële jaar 2016 betreft dus directe betalingen over 2015. 
een inkomen uit bedrijf van $€ 936$ en een gemiddeld bedrag van $€ 312$ aan ontvangen toeslagen uit de eerste pijler.

5. Om een vergelijking te kunnen maken met de verdeling van de inkomenstoeslagen van de eerste pijler op basis van de EC-data, converteren we zowel de 15 ontvangstcategorieën van de EC-data (2017b) als de 7 economische grootteklassen op basis van de FADN-data elk in

10 inkomensdecielen. Op die manier is gemakkelijk af te lezen hoe groot de toeslagen in elk deciel zijn.

FSS: fictieve verdeling van de inkomenstoeslagen op basis van een gemiddelde hectaretoeslag Op basis van de Farm Structure Survey (FSS) wordt per lidstaat een analyse van de bedrijven naar bedrijfsgrootte in hectares gemaakt. Hiermee kunnen verschillen in de verdeling van bedrijven over bedrijfsgrootte-klassen in hectares worden gevisualiseerd. De meest recente FSS waarvoor data beschikbaar zijn, is in 2013 gehouden. We gebruiken het aantal landbouwbedrijven in 2013 als proxy voor het aantal in 2015. Vervolgens maken we een fictieve verdeling van inkomenstoeslagen over de bedrijven in 2015 door van een gemiddelde inkomenstoeslag per hectare per lidstaat uit te gaan. De gemiddelde inkomenstoeslag per hectare berekenen we door de nationale envelop voor 2015 voor elke lidstaat te delen door het aantal hectares landbouwareaal in die lidstaat. De fictieve verdeling is alleen gelijk aan de werkelijke verdeling in het geval alle bedrijven in een lidstaat voor alle hectares een uniforme premie ontvangen. In de praktijk zal de fictieve verdeling een globale benadering van de werkelijkheid zijn, doordat lidstaten een deel van de nationale envelop aan extra betalingen aan jonge boeren, betalingen aan gebieden met een natuurlijke handicap, gekoppelde betalingen etc. besteden en een aantal lidstaten de toeslag op basis van een historische referentie geeft. 


\section{Resultaten}

\subsection{Inleiding}

In paragraaf 3.2 komt de verdeling van de toeslagen over boeren naar de omvang van de ontvangen toeslagen aan de orde. Ook geven we aan hoe die verdeling verandert als er een uniforme hectarepremie zou worden toegekend. Verder besteden we aandacht aan het aantal boeren dat veel of weinig toeslagen ontvangt. In paragraaf 3.3 en 3.4 koppelen we de ontvangen toeslagen aan het landbouwinkomen. In paragraaf 3.3 kijken we naar de verdeling van de toeslagen over boeren gerangschikt naar het inkomen en in paragraaf 3.4 naar het aandeel van de toeslagen in het landbouwinkomen per bedrijfstype.

\subsection{Verdeling van toeslagen over boeren naar omvang toeslagen}

In de economische wetenschap wordt de Lorenzcurve gebruikt om de inkomensverdeling van de bevolking weer te geven. Op de horizontale as staat het cumulatief percentage van de bevolkingsomvang en op de verticale as het cumulatief percentage van de inkomens van diezelfde bevolking. In de Lorenzcurve liggen de punten linksonder en rechtsboven vast: dat zijn de punten waar de cumulatieve bevolkingsomvang en de cumulatieve inkomens beide respectievelijk 0 en $100 \%$ zijn. De lijn tussen die punten geeft aan hoe (on)gelijk het inkomen is verdeeld: loopt de lijn recht, dan is er een gelijke verdeling; loopt de lijn krom, dan is de verdeling ongelijk. We hebben het concept van de Lorenzcurve gebruikt om de verdeling van de inkomenstoeslagen van de eerste pijler over de boeren in de EU28 in 2015 weer te geven (figuur 3.1). Het blijkt dat de verdeling van de inkomenstoeslagen nogal onevenwichtig verloopt: zo'n $80 \%$ van de boeren in de EU28 ontvangt $20 \%$ van de totale inkomenstoeslagen in 2015. De overige $20 \%$ boeren - de groep tussen de $80 \%$ en $100 \%$ op de horizontale as - ontvangt ongeveer $80 \%$ van de toeslagen. Er is dus een grote groep boeren in de EU28 die betrekkelijk weinig toeslagen ontvangt en een kleine groep boeren die betrekkelijk veel toeslagen krijgt.

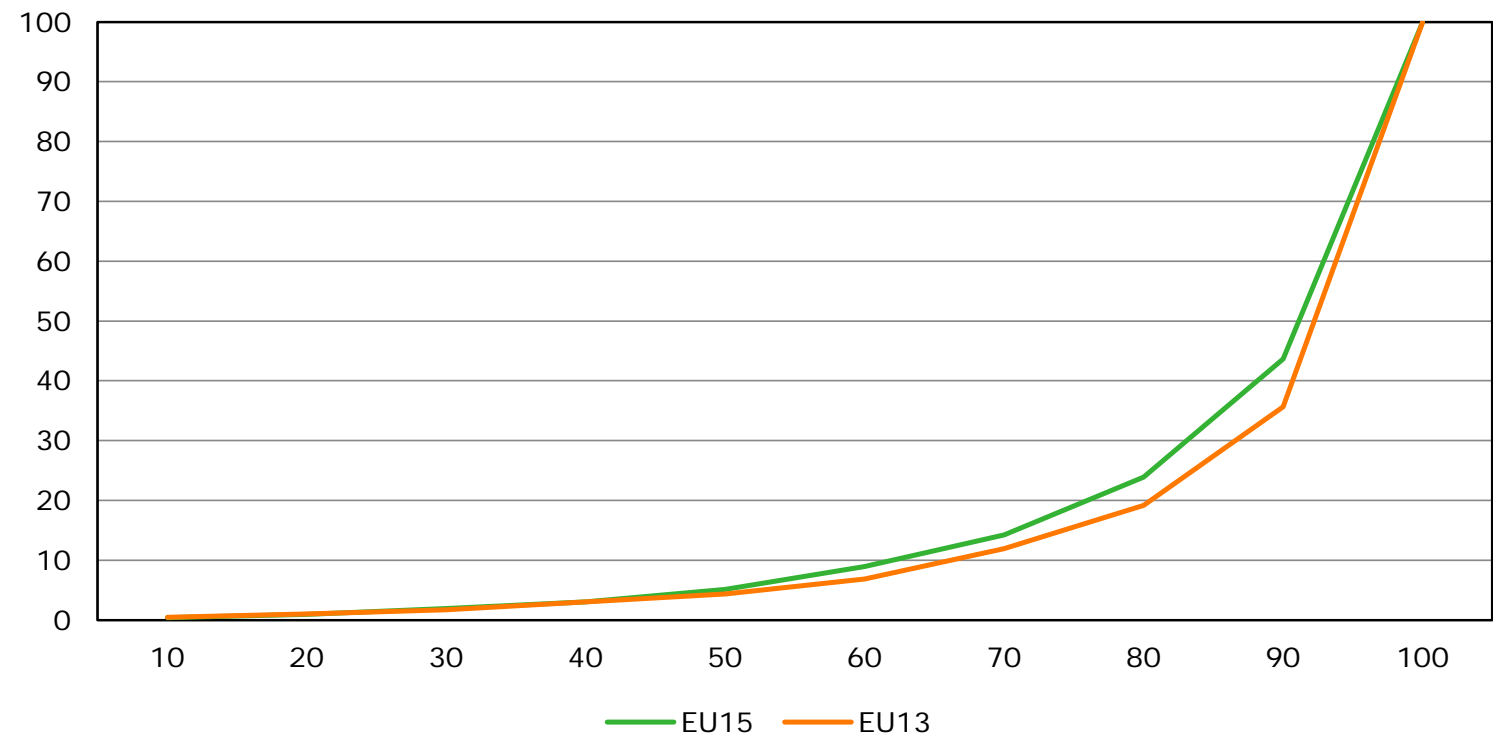

Figuur 3.1 Verdeling van de inkomenstoeslagen van de eerste pijler over boeren in de EU28, 2015 (\%) a)

a) Betreft financieel jaar 2016.

Bron: EC (2017b); bewerking Wageningen Economic Research. 
Onevenwichtigheid in verdeling toeslagen over boeren varieert tussen de lidstaten

De omvang van de groep boeren die $20 \%$ van de inkomenstoeslagen ontvangt loopt nogal uiteen tussen de lidstaten: hij is relatief het kleinst (54\%) in Luxemburg en het grootst (93\%) in Slowakije (figuur 3.2). In Luxemburg is de verdeling van de toeslagen over boeren dus minder ongelijk dan het EU28-gemiddelde, terwijl er in Slowakije juist een meer ongelijke verdeling is. Ook Ierland, Nederland, België, Frankrijk, Finland en Oostenrijk en horen tot de lidstaten met een minder ongelijke verdeling van de toeslagen over boeren ten opzichte van andere EU-landen (tabel B3.1).

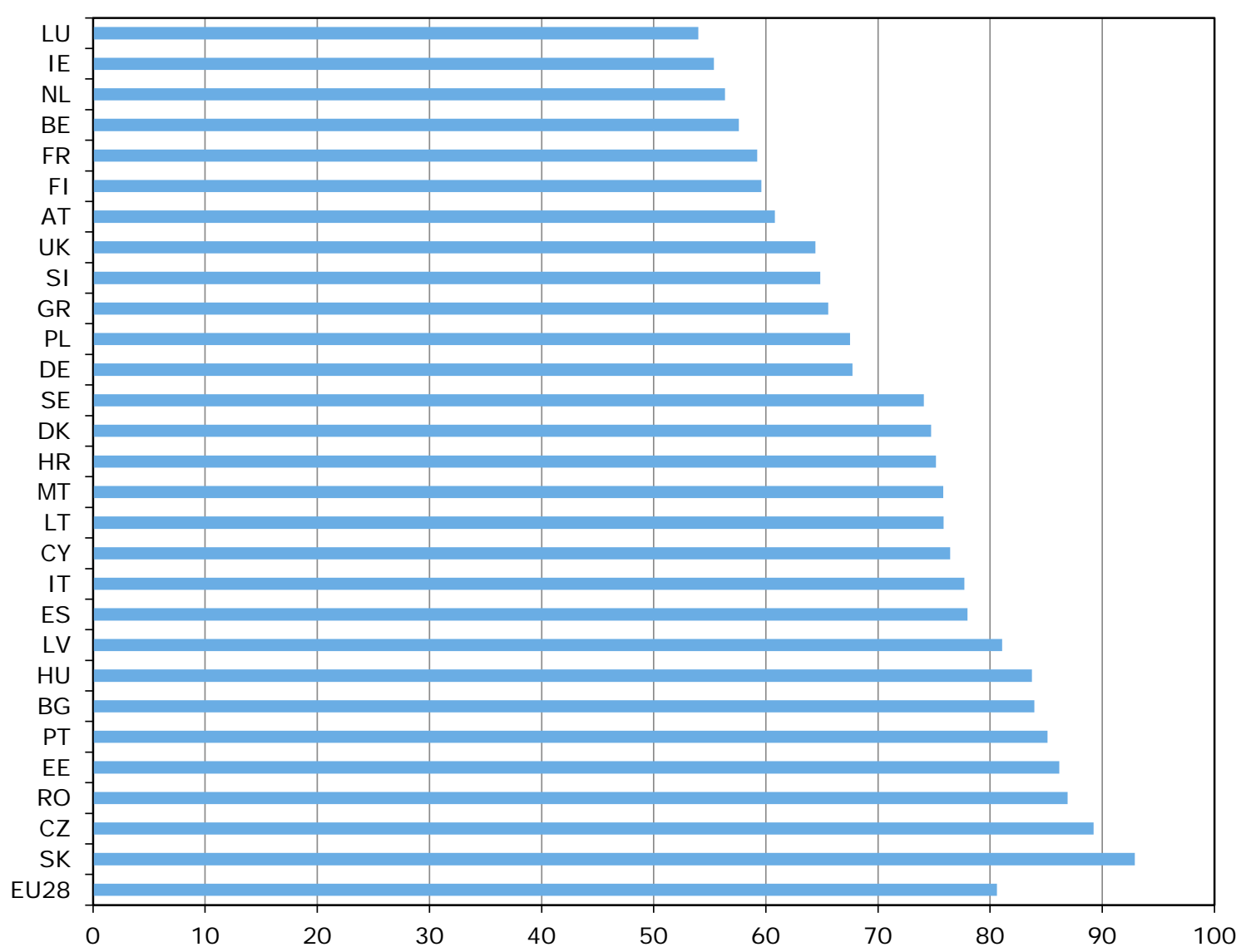

Figuur 3.2 Aandeel boeren in elke EU-lidstaat dat $20 \%$ van de inkomenstoeslagen van de eerste pijler van het GLB ontvangt, 2015 (\% van totaal aantal boeren) Bron: EC (2017b); bewerking Wageningen Economic Research.

Verdeling van toeslagen over bedrijven hangt samen met schaal landbouwstructuur Het verloop van de verdeling van de toeslagen over boeren in de Lorenzcurve heeft te maken met het feit dat niet alle boeren eenzelfde toeslag ontvangen. De toeslag per boer is afhankelijk van de wijze waarop de lidstaat de toeslagen bepaalt (historische referentie, uniforme hectarepremie, gekoppelde betalingen aan de productie, toekennen van optionele toeslagen als compensatie voor natuurlijke handicaps en extra steun voor de eerste hectares etc.). Ondanks verschillen in de berekeningswijze van de toeslag, zijn lidstaten wel gebonden aan regels om de toeslag te laten convergeren naar de gemiddelde toeslag per hectare in hun land. Daardoor ontstaat er een tendens dat boeren op bedrijven met meer hectares meer toeslagen ontvangen dan boeren op bedrijven met minder hectares. Tussen lidstaten bestaan er grote verschillen in de omvang van bedrijven. Zo hebben Malta, Bulgarije, Cyprus en Roemenië een zeer kleinschalige landbouwstructuur waarbij meer dan drie kwart van de landbouwbedrijven kleiner dan 2 ha zijn (tabel 3.1). In een andere groep van lidstaten, bestaande uit Denemarken, Frankrijk, Luxemburg, Tsjechië en het VK, zijn zo'n vijfde van de bedrijven groter dan 100 ha. Tussen deze uitersten zitten twee andere groepen van lidstaten: een groep met een kleinschalige landbouwstructuur waar meer dan $70 \%$ van de landbouwbedrijven kleiner dan 20 ha zijn en een groep lidstaten met een vrij evenwichtige verspreiding van de bedrijven over de 
grootteklassen. Nederland behoort tot deze laatste groep. De spreiding van bedrijven over de grootteklassen beïnvloedt de verdeling van de toeslagen over boeren. Op een paar uitzonderingen na, zoals Griekenland, Polen en Tsjechië, blijkt het dat de lidstaten met een evenwichtige verdeling van de bedrijven over de grootteklassen en lidstaten met relatief veel bedrijven groter dan 100 ha over het algemeen een minder ongelijke verdeling van de toeslagen over boeren hebben dan lidstaten met een zeer kleinschalige en een kleinschalige landbouwstructuur.

Tabel 3.1 Verdeling van het aantal landbouwbedrijven over grootteklassen in ha in de EUlidstaten, 2013

Verdeling bedrijven naar grootteklasse ( $\%$ van totaal)

Totaal aantal Totaal aantal $<2$ ha 2 tot 5 tot 10 tot 20 tot 30 tot 50 tot $>100$ ha bedrijuen bedrijven als 4,9 ha 9,9 ha 19,9 ha 29,9 ha 49,9 ha 99,9 ha

$(* 1,000) \quad \%$ EU totaal

Lidstaten met een zeer kleinschalige landbouwstructuur (meer dan drie kwart van de landbouwbedrijven $<2$ ha)

\begin{tabular}{lllllllllllll}
\hline Malta & 9,4 & 0,1 & 85 & 12 & 3 & 0 & 0 & 0 & 0 & 0 \\
\hline Bulgaria & 254,4 & 2 & 76 & 11 & 4 & 3 & 1 & 1 & 1 & 2 \\
\hline Hungary & 491,3 & 5 & 76 & 9 & 5 & 4 & 2 & 2 & 1 & 2 \\
\hline Cyprus & 35,4 & 0,3 & 75 & 15 & 5 & 3 & 1 & 1 & 1 & 0 \\
\hline Romania & 3629,7 & 33 & 73 & 19 & 5 & 1 & 0 & 0 & 0 & 0
\end{tabular}

Lidstaten met een kleinschalige landbouwstructuur (meer dan $70 \%$ van de landbouwbedrijven $<20$ ha)

\begin{tabular}{lllllllllll}
\hline Greece & 709,5 & 7 & 51 & 25 & 12 & 6 & 2 & 2 & 1 & 0 \\
\hline Portugal & 264,4 & 2 & 46 & 26 & 12 & 7 & 3 & 2 & 2 & 2 \\
\hline Croatia & 157,4 & 1 & 39 & 31 & 16 & 8 & 2 & 2 & 2 & 1 \\
\hline Slovakia & 23,56 & 0,2 & 32 & 27 & 12 & 9 & 3 & 3 & 3 & 10 \\
\hline Spain & 965 & 9 & 28 & 24 & 15 & 11 & 5 & 6 & 5 & 5 \\
\hline Italy & $1.010,3$ & 9 & 28 & 31 & 17 & 11 & 4 & 4 & 3 & 1 \\
\hline Slovenia & 72,4 & 1 & 26 & 34 & 24 & 11 & 3 & 1 & 1 & 0 \\
\hline Poland & $1.429,01$ & 13 & 23 & 31 & 22 & 15 & 4 & 3 & 1 & 1 \\
\hline Latvia & 81,8 & 1 & 23 & 20 & 20 & 19 & 7 & 5 & 3 & 4 \\
\hline Lithuania & 171,8 & 2 & 14 & 39 & 22 & 12 & 4 & 3 & 3 & 3 \\
Austria & 140,4 & 1 & 11 & 20 & 17 & 22 & 12 & 10 & 6 & 2
\end{tabular}

Lidstaten met een evenwichtige verspreiding van de bedrijven over de grootteklassen

\begin{tabular}{lllllllllll}
\hline Ireland & 139,6 & 1 & 2 & 5 & 11 & 24 & 18 & 22 & 15 & 3 \\
\hline Netherlands & 67,5 & 1 & 13 & 15 & 14 & 15 & 10 & 16 & 14 & 4 \\
\hline Belgium & 37,8 & 0,3 & 5 & 9 & 13 & 18 & 13 & 18 & 17 & 6 \\
\hline Finland & 54,4 & 1 & 2 & 3 & 11 & 20 & 15 & 20 & 19 & 8 \\
\hline Estonia & 19,2 & 0 & 11 & 22 & 21 & 17 & 7 & 6 & 6 & 9 \\
\hline Sweden & 67,2 & 1 & 2 & 10 & 23 & 20 & 10 & 11 & 12 & 12 \\
\hline Germany & 285 & 3 & 5 & 3 & 16 & 21 & 10 & 15 & 18 & 12 \\
\hline
\end{tabular}

Germany $285 \quad 3$

\begin{tabular}{lllllllllll}
\hline Czech Republic & 26,3 & 0,2 & 11 & 7 & 19 & 18 & 9 & 9 & 9 & 18 \\
\hline Denmark & 38,3 & 0,4 & 3 & 2 & 20 & 18 & 10 & 11 & 14 & 21 \\
\hline Sprake van France & 472,2 & 4 & 13 & 12 & 9 & 9 & 7 & 10 & 20 & 21 \\
\hline Luxembourg & 2,1 & 0,0 & 10 & 7 & 9 & 8 & 6 & 10 & 29 & 22 \\
\hline United Kingdom & 183 & 2 & 2 & 5 & 15 & 16 & 10 & 13 & 18 & 22 \\
\hline EU28 & & & & & & & & & \\
\hline
\end{tabular}

Bron: Eurostat Farm Structure Survey (FSS); bewerking Wageningen Economic Research.

Ook bij een uniforme hectarepremie verloopt verdeling ongelijk

Gelet op de afspraken over de invulling van het GLB 2014-2020 moeten de inkomenstoeslagen van de eerste pijler per ha intern convergeren naar de gemiddelde hectaretoeslag in een lidstaat of daaraan gelijk worden. In het laatste geval is er sprake van een uniforme hectarepremie, waarbij boeren voor elke ha dezelfde toeslag krijgen. Om na te gaan of de verdeling van inkomenstoeslagen verandert bij het toekennen van een uniforme hectarepremie, hebben we een fictieve verdeling gemaakt. In die fictieve verdeling zijn de bedrijven van boeren gerangschikt naar grootte in hectare: boeren in de 
laagste percielen hebben weinig hectares per bedrijf en boeren in de hoogste percielen veel (tabel 3.2). Door het aantal hectares in elk perciel te vermenigvuldigen met de uniforme hectaretoeslag (figuur 3.3) kunnen we de ontvangsten aan toeslagen in elk percentiel berekenen. Per definitie leidt deze fictieve verdeling tot een ongelijke verdeling van de toeslagen: boeren in de laagste percentielen met weinig hectares per bedrijf ontvangen weinig toeslagen en boeren in de hoogste percentielen met veel hectares per bedrijf krijgen veel meer toeslagen. Uit de fictieve verdeling kunnen we aflezen dat bij een toekenning van een uniforme hectaretoeslag $20 \%$ van de boeren in de EU28 86\% van de toeslagen ontvangt (tabel B3.1). Daarmee laat de fictieve verdeling zien dat een uniforme hectarepremie voor de EU als geheel tot een onevenwichtiger verdeling van de toeslagen over boeren leidt dan de werkelijke verdeling in 2015, waarbij $20 \%$ van de boeren $81 \%$ van de toeslagen ontving. Een gelijke verdeling van toeslagen over boeren kan bij een uniforme hectarepremie pas ontstaan wanneer elk bedrijf in de EU28 evenveel hectares heeft. De huidige verspreiding van bedrijven over de grootteklassen in ha wijkt daar ver van af.

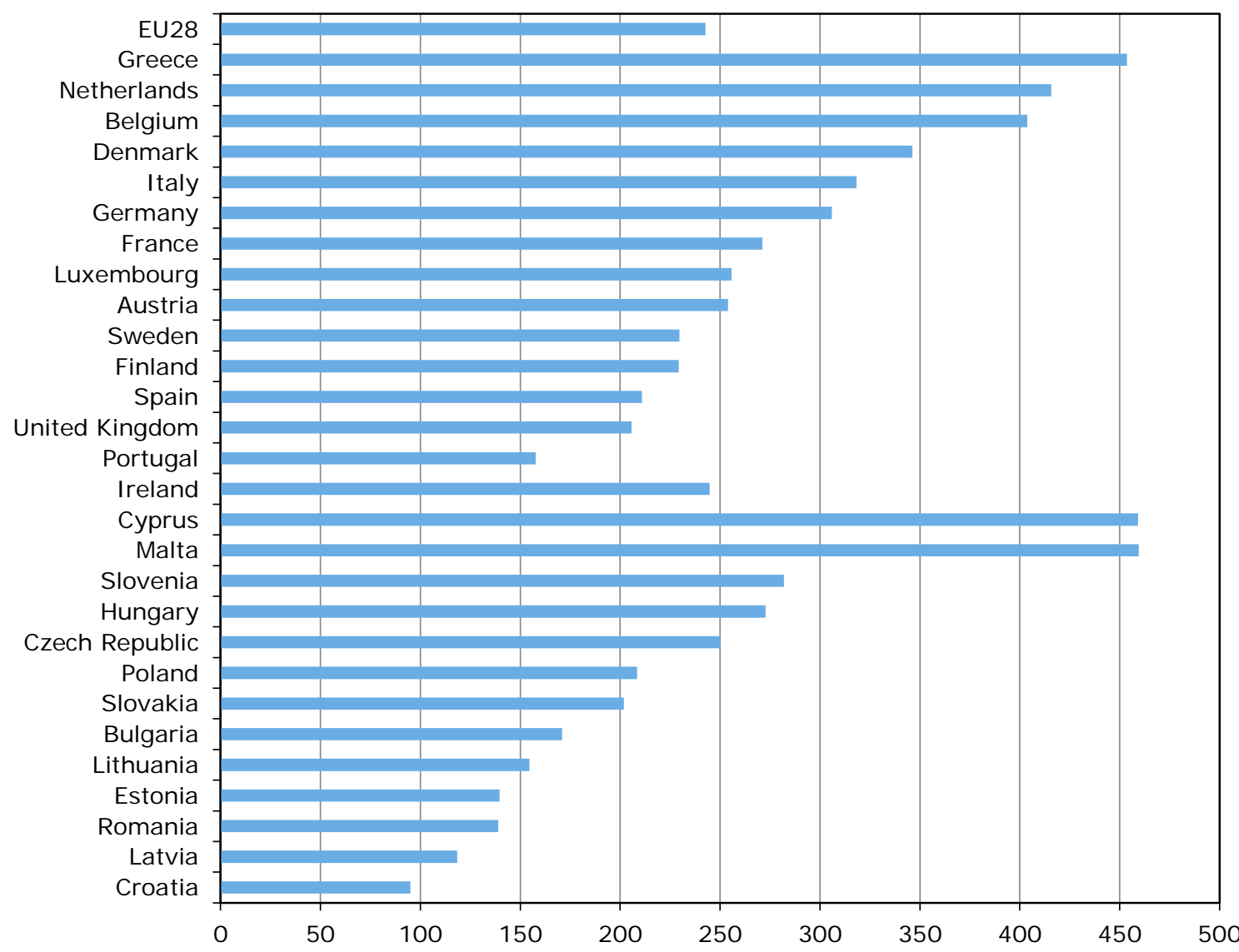

Figuur 3.3 Gemiddelde hectaretoeslag in de EU-lidstaten, 2015 Bron: EC (2013) en Eurostat Farm Structure Survey (FSS); bewerking Wageningen Economic Research.

Fictieve verdeling van een uniforme hectaretoeslag in de lidstaten Op dezelfde manier als voor de EU28 hebben we ook per lidstaat een fictieve verdeling van uniforme hectaretoeslagen over landbouwbedrijven gemaakt (bijlage B.1). Als we de verdeling op basis van uniforme toeslagen vergelijken met de verdeling van de toegekende toeslagen in 2015 (EC, 2017b), blijkt dat in een aantal lidstaten (Denemarken, Finland, Ierland, Italië, Letland, Malta, Polen, Roemenië, Slovenië, Slowakije, Tsjechië en Zweden) de verdeling minder ongelijk wordt, terwijl de verdeling in andere lidstaten (Bulgarije, Cyprus, Frankrijk, Griekenland, Hongarije, Kroatië, Luxemburg, Nederland, Portugal, Spanje en het VK) juist ongelijker wordt (tabel B3.1). Er is ten slotte ook een groep van lidstaten waar de verdeling ongewijzigd blijft (België, Duitsland, Estland, Litouwen en Oostenrijk). In Nederland ontving $20 \%$ van de boeren op basis van de toegekende toeslag $56 \%$ 
van de toeslagen in 2015; bij de fictieve verdeling op basis van een uniforme hectarepremie van $€ 416$ wordt dat $63 \%$, wat een minder gelijke verdeling betekent. De reden waarom in sommige lidstaten de verdeling minder gelijk wordt en in andere lidstaten meer gelijk, blijkt niet samen te hangen met de verdeling van de landbouwbedrijven over de grootteklassen in ha (tabel 3.1). Kennelijk spelen landspecifieke factoren zoals historische referenties voor het bepalen van een toeslag, een rol in de richting waarin de verdeling verschuift.

Tabel $3.2 \quad$ Fictieve verdeling van een uniforme hectaretoeslag over boeren in de EU28, 2015 a)

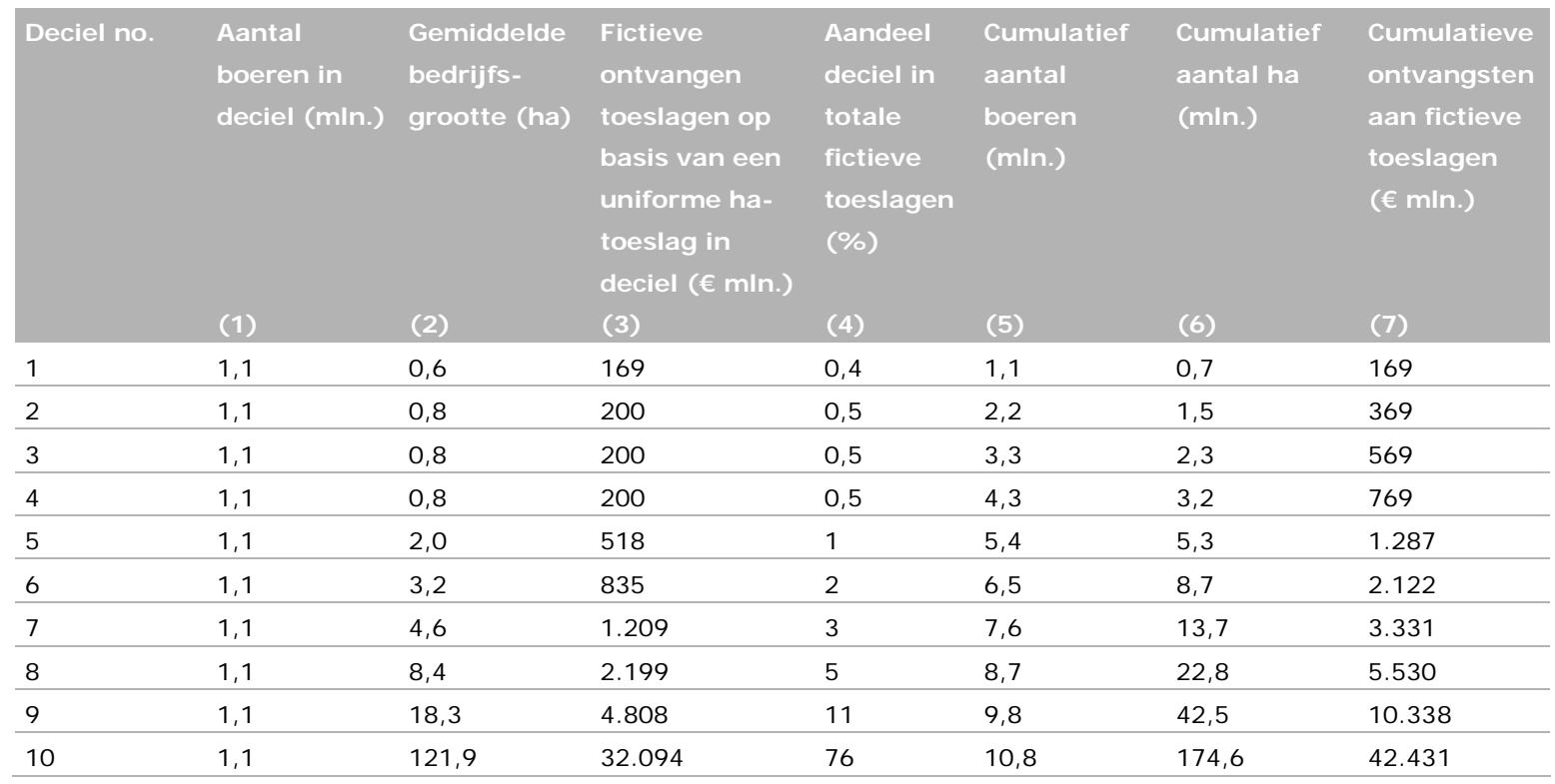

a) Kolom (3): berekend als aantal boeren in deciel * aantal ha per boer * uniforme hectarepremie van $€ 243$;

Kolom (4): berekend als kolom (3) gedeeld door het totaal aantal toeslagen in de EU28 (€ 4.2431; laatste getal kolom (7));

Kolom (6): berekend als kolom (1)* kolom (2); het totaal van de voorgaande decielen wordt er vervolgens bij opgeteld.

Bron: EC (2013) en Eurostat Farm Structure Survey (FSS); bewerking Wageningen Economic Research.

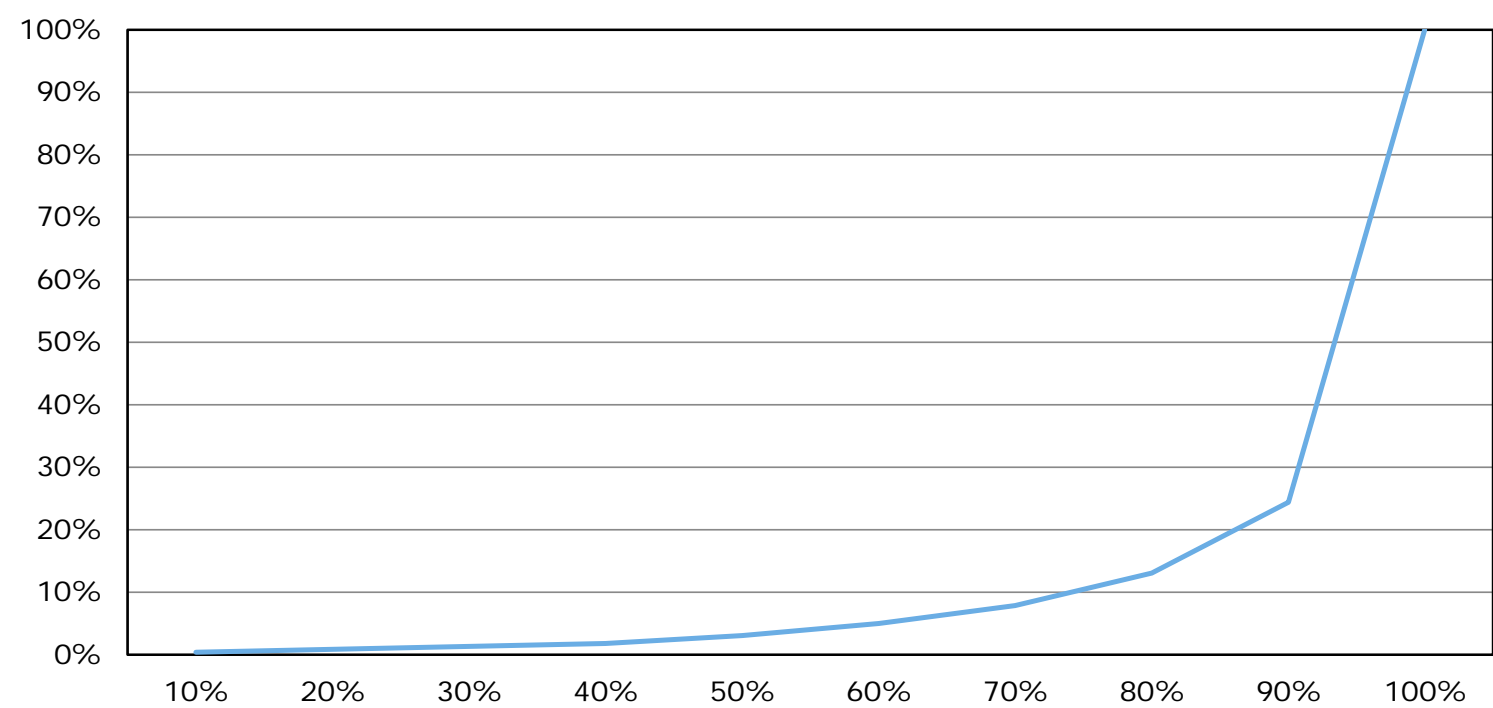

Figuur 3.4 Fictieve verdeling van de toeslagen op basis van een uniforme hectarepremie over bedrijven in de EU28, 2015

Bron: EC (2013) en Eurostat Farm Structure Survey (FSS); bewerking Wageningen Economic Research. 


\section{Bedrijven met weinig of veel toeslagen}

In 2015 ontving 27\% van de boeren in de EU28, die in aanmerking komen voor directe betalingen uit de eerste pijler van het GLB, een toeslag van minder dan $€ 500$ (tabel 3.3). Dit percentage varieerde van minder dan een half procent in Denemarken en Nederland tot $72 \%$ op Malta. Er blijken maar weinig boeren te zijn die wel recht hebben op een toeslag, maar die niet ontvangen: in de EU28 ging het om 2.307 boeren, vooral afkomstig uit Italië, Kroatië en Litouwen (tabel B3.2). Kennelijk voorziet de regeling voor kleine landbouwbedrijven in de behoefte van kleine boeren om op een betrekkelijk eenvoudige wijze een toeslag aan te kunnen vragen. lets minder dan 16.000 boeren in de EU28 ontvingen in 2015 meer dan $€ 150.000$ aan toeslagen. De meesten daarvan hebben een bedrijf in Duitsland (ruim 3.300), in Italië, Spanje, Tsjechië en het VK (1.500-1.600), en in Bulgarije, Denemarken, Frankrijk, Hongarije, Polen, Roemenië en Slowakije (600-1.100) (figuur 3.5). In Nederland ontvingen ruim 100 boeren in 2015 meer dan $€ 150.000$ aan toeslagen. In percentages van het totaal aantal ontvangers van toeslagen is de groep van grote ontvangers erg klein: in de EU28 gaat het om $0,2 \%$ van de ontvangers. Alleen in Slowakije en Tsjechië was het percentage met circa $5 \%$ wat groter. Het aandeel van deze groep van grote ontvangers in de totale toeslagen beliep $11 \%$ in 2015 in de EU28. Tussen lidstaten varieert dit aandeel nogal: van nihil in Griekenland en op Malta tot $69 \%$ in Slowakije (figuur 3.6). In Nederland bedraagt het aandeel 3\%.

Drie kwart van boeren in de EU28 ontving in 2015 minder dan $€ 5.000$ aan toeslagen Zo'n drie kwart van de boeren in de EU28 ontving in 2015 minder dan $€ 5.000$ aan toeslagen (tabel B3.3). Daarbij viel een kwart van de boeren in de categorie van minder dan $€ 500$, een kwart in de categorie van tussen de $€ 500$ en $€ 1.250$, en een kwart in de categorie van tussen $€ 1.250$ en $€ 5.000$.

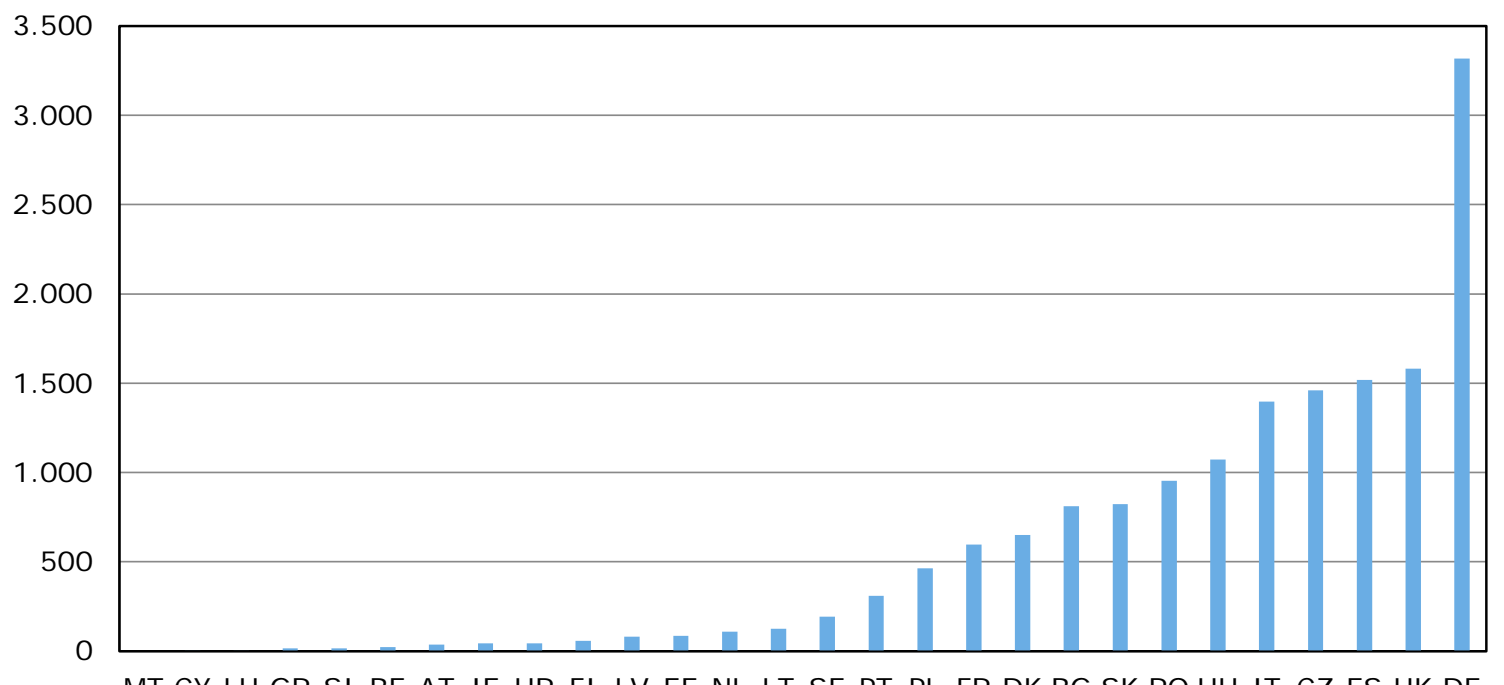

MT CY LU GR SI BE AT IE HR FI LV EE NL LT SE PT PL FR DK BG SK RO HU IT CZ ES UK DE

Figuur 3.5 Aantal boeren dat meer dan $€ 150.000$ aan toeslagen ontvangt in de EU-lidstaten, 2015 Bron: EC (2017b); bewerking Wageningen Economic Research. 
Tabel 3.3 Boeren die weinig en veel toeslagen ontvangen in de EU-lidstaten, 2015 ( $\%$ totaal aantal boeren)

\begin{tabular}{|c|c|c|c|}
\hline & \multicolumn{2}{|l|}{ Weinig toeslagen } & \multirow{2}{*}{$\begin{array}{l}\text { Veel toeslagen } \\
\% \text { boeren dat meer dan } € 150.000 \text { aan } \\
\text { toeslagen ontvangt }\end{array}$} \\
\hline & $\begin{array}{l}\% \text { boeren dat geen } \\
\text { toeslag ontvangt }\end{array}$ & $\begin{array}{l}\% \text { boeren dat } € \text { 0-500 aan } \\
\text { toeslagen ontvangt }\end{array}$ & \\
\hline$C Z$ & 0,0 & 10,3 & 5,0 \\
\hline SK & 0,0 & 22,8 & 4,5 \\
\hline DK & 0,2 & 0,3 & 1,6 \\
\hline BG & 0,0 & 12,2 & 1,2 \\
\hline UK & 0,0 & 0,8 & 1,1 \\
\hline $\mathrm{DE}$ & 0,0 & 4,4 & 1,0 \\
\hline $\mathrm{HU}$ & 0,1 & 4,8 & 0,6 \\
\hline $\mathrm{EE}$ & 0,0 & 26,5 & 0,5 \\
\hline SE & 0,0 & 0,9 & 0,3 \\
\hline $\mathrm{NL}$ & 0,0 & 0,4 & 0,2 \\
\hline ES & 0,0 & 24,2 & 0,2 \\
\hline PT & 0,0 & 52,4 & 0,2 \\
\hline $\mathrm{FR}$ & 0,0 & 4,9 & 0,2 \\
\hline IT & 0,1 & 23,3 & 0,2 \\
\hline LV & 0,0 & 18,0 & 0,1 \\
\hline $\mathrm{FI}$ & 0,0 & 1,7 & 0,1 \\
\hline LU & 0,0 & 4,4 & 0,1 \\
\hline RO & 0,0 & 64,6 & 0,1 \\
\hline $\mathrm{LT}$ & 0,4 & 31,7 & 0,1 \\
\hline $\mathrm{BE}$ & 0,0 & 1,9 & 0,1 \\
\hline $\mathrm{HR}$ & 0,4 & 43,2 & 0,0 \\
\hline IE & 0,0 & 4,0 & 0,0 \\
\hline $\mathrm{PL}$ & 0,0 & 28,7 & 0,0 \\
\hline AT & 0,0 & 10,8 & 0,0 \\
\hline SI & 0,0 & 25,2 & 0,0 \\
\hline $\mathrm{CY}$ & 0,1 & 55,9 & 0,0 \\
\hline GR & 0,0 & 20,2 & 0,0 \\
\hline MT & 0,0 & 72,0 & 0,0 \\
\hline EU28 & 0,0 & 26,7 & 0,2 \\
\hline
\end{tabular}

Bron: EC (2017b); bewerking Wageningen Economic Research.

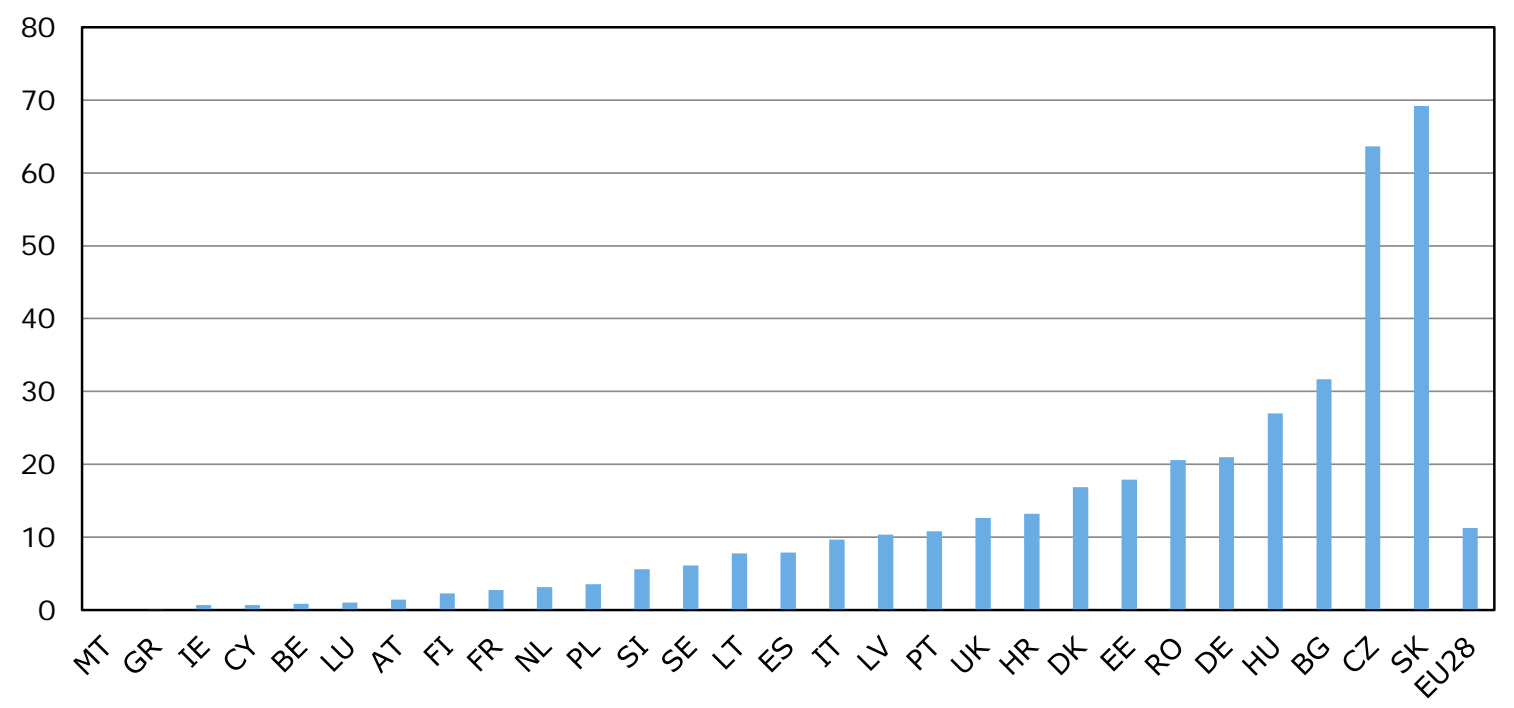

Figuur 3.6 Aandeel boeren die meer dan $€ 150.000$ aan toeslagen ontvangen in totale toeslagen in de EU-lidstaten, 2015 (\% van totaal aantal toeslagen)

Bron: EC (2017b); bewerking Wageningen Economic Research. 


\subsection{Verdeling van toeslagen over boeren naar economische grootteklasse bedrijven}

In de vorige paragraaf hebben we de verdeling van toeslagen over bedrijven en boeren besproken, waarbij we ook aandacht hebben besteed aan de grootte van bedrijven in hectares. De bijdrage van de inkomenstoeslagen aan het landbouwinkomen is daarbij echter niet behandeld. Dat doen we in deze paragraaf op basis van data van het Farm Accountancy Data Network (FADN). Met behulp van deze data kunnen we landbouwbedrijven in zogenaamde economische grootteklassen verdelen die weerspiegelen wat de gestandaardiseerde verdiencapaciteit op jaarbasis van de bedrijven in elke klasse is. Hoe groter de verdiencapaciteit van een klasse, hoe hoger het gemiddelde landbouwinkomen van de bedrijven uit die groep is. Omdat FADN alleen gericht is op commerciële landbouwbedrijven, valt een deel van de -vooral kleine - bedrijven die wel in de EC-data over de verdeling van de toeslagen over ontvangers zitten, buiten de FADN-data. Om zo goed mogelijk de bijdrage van de toeslagen in het landbouwinkomen van alle bedrijven te kunnen schatten, hebben we de EC-data gekoppeld aan de FADN-data volgens de veronderstellingen die in hoofdstuk 2 zijn beschreven. Door deze koppeling wordt het mogelijk om zo'n 96\% van zowel alle ontvangers van toeslagen als de totale toeslagen uit de EC-data in de berekeningen in deze paragraaf mee te nemen.

Verdeling toeslagen gerangschikt naar hoogte inkomen boeren iets minder onevenwichtig De verdeling van de toeslagen over boeren gerangschikt naar de hoogte van het inkomen laat zien dat de groep van $80 \%$ boeren met de laagste inkomens in de EU28 zo'n 25\% van de toeslagen ontvangt (figuur 3.7). Dit beeld wijkt daarmee iets af van de $80-20 \%$-verdeling van boeren over de toeslagklassen (figuur 3.1). Deze afwijking hangt enerzijds samen met bedrijven die een laag inkomen hebben, maar veel toeslagen ontvangen en anderzijds met bedrijven die een hoog inkomen hebben maar juist relatief weinig toeslagen ontvangen (Matthews, 2016). Tot de eerste groep behoren onder meer extensieve schapenbedrijven; tot de tweede groep tuinbouwbedrijven.

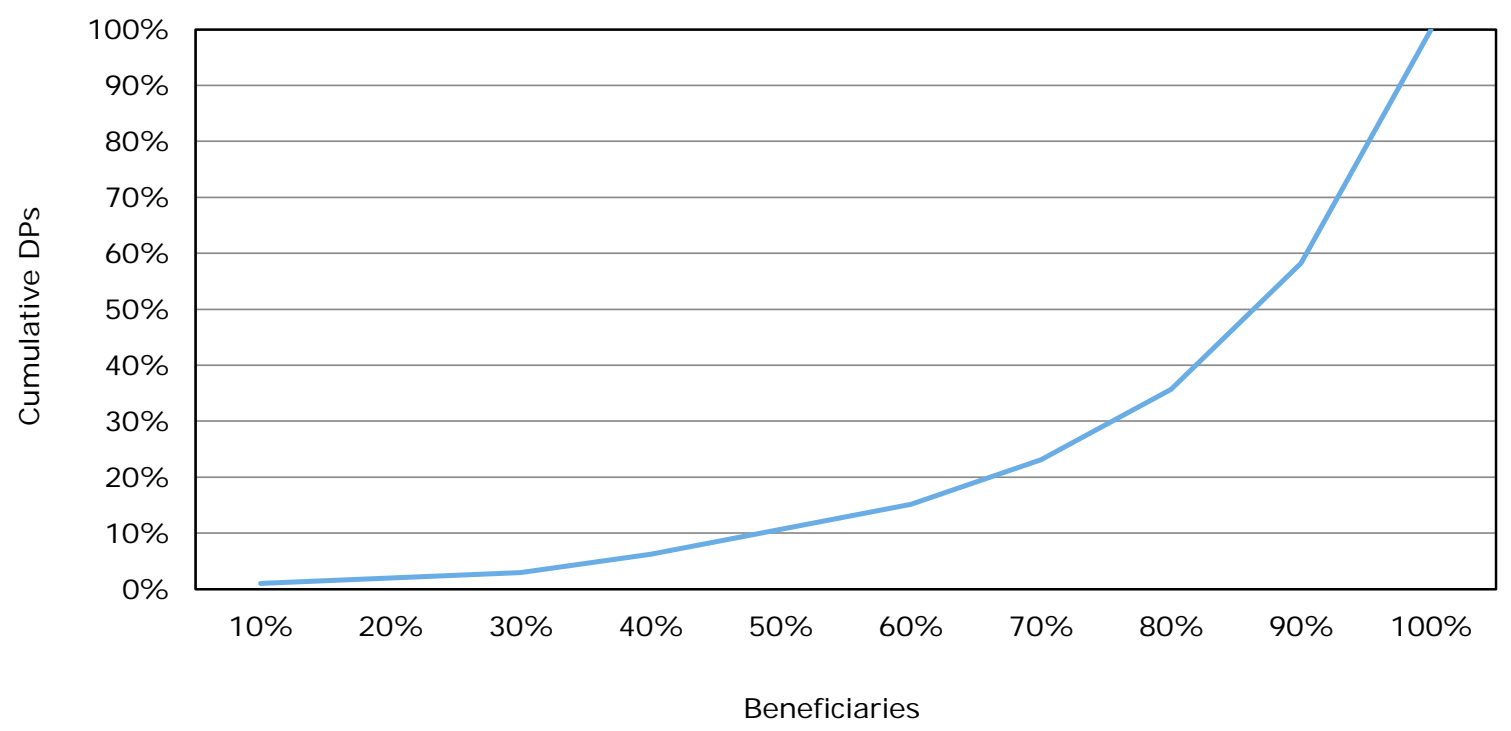

Figuur 3.7 Verdeling van de toeslagen over boeren gerangschikt naar de hoogte van het inkomen in de EU28, 2015

DP: toeslagen eerste pijler GLB.

Bron: FADN en EC (2017b); bewerking Wageningen Economic Research.

Boeren in hoogste inkomensdeciel ontvangen zo'n 55\% van de toeslagen De gemiddelde landbouwinkomens uit bedrijf inclusief toeslagen in de EU28 in de inkomensdecielen lopen fors uiteen: van minder dan $€ 1.000$ in het eerste deciel tot meer dan $€ 65.000$ in het laatste deciel (tabel 3.4). Het aandeel van de toeslagen in het inkomen in de EU28 is aanzienlijk en varieert van een derde tot de helft. De 50\% van de boeren die de laagste inkomens hebben (deciel 1-5) ontvingen in 2015 zo'n 4\% van de totale toeslagen, terwijl de 10\% boeren in het hoogste deciel 53\% 
van alle toeslagen ontvingen. Naarmate het inkomen uit bedrijf hoger wordt, ontvangen boeren dus gemiddeld een hogere inkomenstoeslag. Deze constatering is niet nieuw en heeft in de literatuur regelmatig tot de opmerking geleid dat het GLB niet effectief is als inkomensbeleid en dat sociaal beleid een meer geëigend instrument zou zijn om landbouwinkomens te ondersteunen (Matthews, 2016). Daarbij kan bijvoorbeeld worden gedacht aan een persoonsgebonden toeslag die gerelateerd is aan het regionale minimuminkomen (Vogelzang et al., 2016). Verder wordt het landbouwinkomen op veel bedrijven aangevuld met inkomsten uit niet-agrarische activiteiten, uitkeringen en pensioenen. Data over het totale huishoudinkomen op landbouwbedrijven ontbreken grotendeels, en worden in de FADN-data niet meegenomen (Strijker, 2017). Als we rekening houden met die aanvullende inkomens, komen de inkomens uit het landbouwbedrijf in een heel ander daglicht te staan. In veel gevallen zou er dan sprake kunnen zijn een 'redelijk inkomen voor het gezinsbedrijf'. In de EU28 heeft zo'n derde van het totaal aantal bedrijven inkomsten uit nevenactiviteiten (Terluin et al., 2017). Dit percentage vertoont grote verschillen tussen lidstaten: in Zweden gaat het om slechts $6 \%$ van de bedrijven; in Bulgarije, Finland en Slovenië heeft 70-80\% van de bedrijven neveninkomsten.

Tabel 3.4 Inkomen per bedrijf en toeslagen per bedriff in de inkomensdecielen in de EU28, 2015

\begin{tabular}{|c|c|c|c|c|c|c|c|c|}
\hline Deciel no. & $\begin{array}{l}\text { Cumulatief } \\
\text { aantal } \\
\text { bedrijven } \\
(* 1.000)\end{array}$ & $\begin{array}{l}\text { Gemiddelde } \\
\text { toeslag per } \\
\text { bedrijf (€) }\end{array}$ & $\begin{array}{l}\text { Totale } \\
\text { toeslagen } \\
\text { per deciel } \\
\text { ( } € \mathrm{mln} . \text { ) }\end{array}$ & $\begin{array}{l}\text { Gemiddeld } \\
\text { inkomen a) } \\
\text { per bedrijf } \\
\text { (€) }\end{array}$ & $\begin{array}{l}\text { Totaal } \\
\text { inkomen } \\
\text { per deciel } \\
\text { ( } € \text { mln.) }\end{array}$ & $\begin{array}{l}\text { Gemiddelde } \\
\text { toeslag als } \\
\% \\
\text { gemiddeld } \\
\text { inkomen }\end{array}$ & $\begin{array}{l}\text { Totale } \\
\text { toeslagen } \\
\text { per deciel } \\
\text { als \% van } \\
\text { totale } \\
\text { toeslagen }\end{array}$ & $\begin{array}{l}\text { Totaal } \\
\text { inkomen } \\
\text { per deciel } \\
\text { als \% van } \\
\text { totaal } \\
\text { inkomen }\end{array}$ \\
\hline & (1) & (2) & $(646.000)$ & (3) & $(646.000)$ & $(2) /(3)$ & $(646.000)$ & $(646.000)$ \\
\hline & & & $*(2)$ & & $*(3)$ & & $*(2) /$ & $*(3) /$ \\
\hline & & & & & & & $\begin{array}{l}€ 40.091 \\
\mathrm{mln} .\end{array}$ & $\begin{array}{l}€ 83.451 \\
\mathrm{mln} .\end{array}$ \\
\hline 1 & 646 & 312 & 201 & 936 & 604 & 33 & 0,5 & 0,5 \\
\hline 5 & 3.229 & 834 & 539 & 2084 & 1.346 & 40 & 1,3 & 1,3 \\
\hline 6 & 3.874 & 3.233 & 2.087 & 7.468 & 4.822 & 43 & 5,2 & 5,2 \\
\hline 7 & 4.520 & 3.766 & 2.432 & 8.665 & 5.595 & 43 & 6,1 & 6,1 \\
\hline 8 & 5.166 & 6.642 & 4.289 & 13.713 & 8.855 & 48 & 10,7 & 10,7 \\
\hline 9 & 5.811 & 12.770 & 8.246 & 25.436 & 16.424 & 50 & 20,6 & 20,6 \\
\hline 10 & 6.457 & 32.956 & 21.280 & 66.720 & 43.082 & 49 & 53,1 & 53,1 \\
\hline Totaal & 6.457 & - & 40.091 & - & 83.451 & - & - & - \\
\hline
\end{tabular}

a) Gezinsinkomen uit bedrijf (FADN-variabele SE420).

Bron: FADN; bewerking Wageningen Economic Research.

\subsection{Aandeel van de inkomenstoeslag in het landbouwinkomen per bedrijfstype}

FADN deelt de landbouwbedrijven in een aantal bedrijfstypen in: gespecialiseerde bedrijven met granen, oliezaden en eiwitgewassen, overige gespecialiseerde akkerbouwbedrijven, gespecialiseerde melkveebedrijven, gespecialiseerde schapen- en geitenbedrijven, gespecialiseerde vleeskoeienbedrijven en gespecialiseerde intensieve veehouderijbedrijven. Daardoor wordt het mogelijk om verschillen in ontvangen toeslagen en de omvang van het inkomen per bedrijfstype in beeld te brengen. Ook kunnen we met de FADN-data berekenen wat het aandeel van de toeslagen in het inkomen per bedrijfstype is. Omdat de landbouwinkomens van jaar tot jaar nogal kunnen fluctueren, kunnen de aandelen van de toeslagen in het landbouwinkomen van jaar tot jaar wat verschillen van elkaar (Van der Meulen et al., 2017). In de analyse in deze paragraaf benaderen we het landbouwinkomen met het gezinsinkomen uit bedrijf per gezinsarbeidskracht. 
Gemiddeld ligt het aandeel van de toeslag in het gezinsinkomen uit bedrijf per gezinsarbeidskracht op de overige akkerbouwbedrijven, melkveebedrijven, en schapen- en geitenbedrijven in de EU28 in de periode 2004-2015 tussen zo'n 50 en 70\% (figuur 3.8). Het aandeel op de vleeskoeienbedrijven komt ruim boven de $100 \%$ uit: op die bedrijven zouden de inkomens dus negatief worden zonder toeslagen. Ook op de bedrijven met granen, oliezaden en eiwitgewassen ligt het aandeel van de toeslagen in de buurt van de $100 \%$. Het aandeel van de toeslagen in het inkomen op de intensieve veehouderijbedrijven is relatief laag: dat komt doordat het landbouwareaal op deze bedrijven gering is en er geen traditie van veel GLB-ondersteuning op deze bedrijven bestaat.

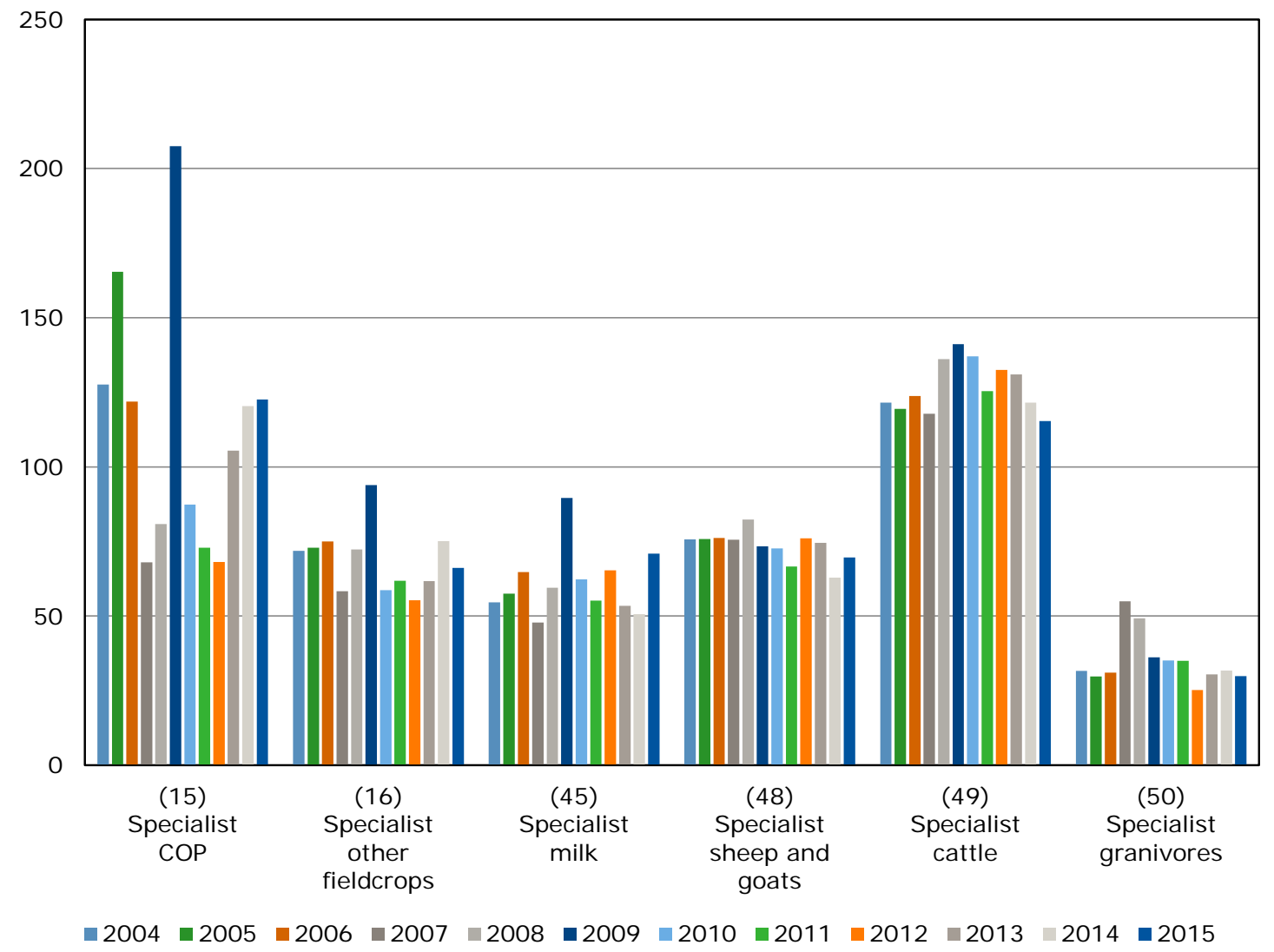

Figuur 3.8 Aandeel van de toeslagen van de eerste pijler van het GLB in het gezinsinkomen uit bedrijf per gezinsarbeidskracht naar bedrijfstype in de EU28, 2004-2015 Bedrijfstype (15) Specialist COP zijn gespecialiseerde bedrijven met granen, oliezaden en eiwitgewassen.

Bron: FADN; bewerking Wageningen Economic Research.

Gezinsinkomens liggen vaak onder bbp/capita

Door het inkomen op landbouwbedrijven met een maatstaf voor het gemiddelde inkomen in een regio of lidstaat te vergelijken, kunnen we beoordelen of het gezinsinkomen uit bedrijf per gezinsarbeidskracht in de landbouw relatief hoog of laag is. Als referentie-inkomen gebruiken we het bruto binnenlands product (bbp) per capita. Hoewel dit inkomen vrij laag is omdat het ook de inkomsten van de niet-actieven als kinderen en gepensioneerden bevat, heeft dit als grote voordeel boven andere inkomensreferenties dat de bbp-data in de EU geharmoniseerd zijn en voor alle lidstaten beschikbaar zijn. In de meeste lidstaten ligt het gezinsinkomen uit bedrijf per gezinsarbeidskracht onder het bbp/capita (tabel B3.5). Wel zijn in België, Bulgarije, Duitsland, Frankrijk, Griekenland, Letland, Litouwen, Nederland, Roemenië en het VK één of twee bedrijfstypen aanwezig waar een inkomen per arbeidskracht boven het bbp/capita wordt behaald. In Hongarije, Italië, Spanje, Slowakije, en Tsjechië daarentegen liggen de gezinsinkomens uit bedrijf echter voor de meeste bedrijfstypen boven het bbp/capita. Bij de interpretatie van deze cijfers moet worden bedacht dat op 
redelijk wat landbouwbedrijven aanvullende inkomsten bestaan uit nevenactiviteiten, pensioenen en uitkeringen (zie ook paragraaf 3.3).

De toeslagen uit de eerste pijler per gezinsarbeidskracht op de verschillende bedrijfstypen in de EUlidstaten waren in 2015 gemiddeld hooguit $€ 47.000$, met uitzondering van Slowakije en in mindere mate Tsjechië, waar de gemiddelde toeslagen aanzienlijk hoger zijn ( $€ 65.000-€ 178.000$ ) (tabel B3.6). Alle lidstaten, behalve België, Italië, Malta, Portugal, Roemenië en Spanje, hebben één of meerdere bedrijfstypen waar de inkomenstoeslagen meer dan $100 \%$ van het inkomen uitmaken (figuur B2.1-22; tabel B3.7). Zonder toeslagen zouden de gezinsinkomens uit bedrijf in de landbouw per gezinsarbeidskracht op die bedrijfstypen negatief worden (tabel B3.8). Een negatief landbouwinkomen geeft aan dat de kosten die samenhangen met de landbouwproductie hoger zijn dan de opbrengsten ervan. 


\section{$4 \quad$ Conclusies}

In het kader van de eerste pijler van het GLB ontvangen boeren inkomenstoeslagen. Deze zijn bedoeld om te zorgen voor redelijke inkomens in de landbouw. In deze studie is nagegaan hoe de inkomenstoeslagen in 2015 over de landbouwbedrijven in de EU zijn verdeeld en welke verschillen zich daarbij tussen de lidstaten voordoen.

In 2015 ontving 81\% van de boeren in de EU28 20\% van de inkomenstoeslagen De verdeling van de inkomenstoeslagen van de eerste pijler van het GLB laat een onevenwichtig beeld zien: in 2015 ontving 81\% van de boeren in de EU28 20\% van de inkomenstoeslagen. Er is dus een grote groep boeren in de EU28 die betrekkelijk weinig toeslagen ontvangt en een kleine groep boeren die betrekkelijk veel toeslagen krijgt. De omvang van de groep boeren die $20 \%$ van de inkomenstoeslagen ontvangt loopt nogal uiteen tussen de lidstaten: hij is relatief het kleinst (54\%) in Luxemburg en het grootst (93\%) in Slowakije. Daarmee is de verdeling in Luxemburg minder ongelijk dan het EU28-gemiddelde, terwijl er in Slowakije juist een meer ongelijke verdeling is. Ook in Nederland is de verdeling minder ongelijk dan het EU28-gemidelde: in 2015 ontving 56\% van de boeren in ons land $20 \%$ van de toeslagen.

Onevenwichtige verdeling van de toeslagen hangt voor deel samen met verschil in bedrijfsgrootte De inkomenstoeslagen zijn deels gebaseerd op het aantal hectares per landbouwbedrijf en deels op landspecifieke elementen zoals historische referenties en gekoppelde betalingen. Zolang het GLB lidstaten verschillende opties voor de wijze van toekennen van de toeslagen biedt zijn wegens het toepassen van specifieke opties verschillen tussen de lidstaten in de verdeling van de toeslagen over boeren te verwachten. Maar ook in het geval dat lidstaten alleen een uniforme hectarepremie zouden mogen toekennen resulteert een ongelijke verdeling van toeslagen over de boeren. Uit een fictieve verdeling van de toeslagen op basis van een uniforme hectarepremie blijkt dat deze een nog onevenwichtiger verdeling laat zien dan de werkelijke verdeling in 2015: in dat geval ontvangt 86\% van de boeren in de EU28 20\% van de toeslagen. Bij die fictieve verdeling ontvangen boeren met weinig hectares weinig toeslagen en boeren met veel hectares veel toeslagen. De groep boeren met weinig hectares is veel groter dan de groep met veel hectares: in 2013 had $45 \%$ van de landbouwbedrijven in de EU28 minder dan 2 ha, 41\% tussen de 2 en 20 ha, 11\% tussen de 20 en 100 ha en $3 \%$ meer dan 100 ha. De verdeling van de landbouwbedrijven over de grootteklassen in individuele lidstaten fluctueert nogal rondom dit EU-gemiddelde. Een gelijke verdeling van toeslagen over boeren kan bij een uniforme hectarepremie pas ontstaan wanneer elk bedrijf in de EU28 evenveel hectares heeft. De huidige verspreiding van bedrijven over de grootteklassen in ha wijkt daar ver van af.

Structuurkenmerken van bedrijven die veel of weinig toeslagen ontvangen

De omvang van de ontvangen toeslagen loopt fors uiteen: in 2015 ontving ruim een kwart van de boeren in de EU28 een toeslag van minder dan $€ 500$ en $0,2 \%$ een toeslag van meer dan $€ 150.000$. Slechts een beperkt aantal boeren (zo'n 2300 boeren in de EU28) die wel in aanmerking kwamen voor toeslagen, ontving ze in 2015 niet. Omdat de EC-data (2017b) over de verdeling van de toeslagen over boeren niet gepaard gaan met data over andere kenmerken van de boeren, kunnen we alleen via het koppelen van de EC-data aan andere databestanden de structuurkenmerken van bedrijven met weinig en veel toeslagen benaderen. Dit leidt tot de volgende observaties:

- bedrijven met minder toeslagen hebben doorgaans minder hectares dan bedrijven met veel toeslagen;

- naarmate de inkomens op bedrijven hoger zijn, gaat de omvang van de ontvangen toeslagen ook vaak omhoog;

- gespecialiseerde vleeskoeienbedrijven en bedrijven met granen, oliezaden en eiwitgewassen ontvangen gemiddeld in de EU28 relatief de hoogste toeslagen en intensieve veehouderijbedrijven de laagste. Overige gespecialiseerde akkerbouwbedrijven, melkveebedrijven en schapen- en geitenbedrijven nemen een tussenpositie in. 
Bedacht moet worden dat deze drie observaties gebaseerd zijn op EU-gemiddelden en dat de situatie op individuele bedrijven hiervan kan afwijken.

Aandeel toeslagen in het landbouwinkomen loopt sterk uiteen

De 50\% van de boeren in de EU28 die de laagste inkomens hebben ontvingen in 2015 zo'n $4 \%$ van de totale toeslagen, terwijl de $10 \%$ boeren met de hoogste inkomens 53\% van alle toeslagen ontvingen. Het aandeel van de toeslagen in het gezinsinkomen uit bedrijf per gezinsarbeidskracht in de EU28 is aanzienlijk en varieert van een derde bij de lagere inkomensklassen tot de helft in de hogere inkomensklassen. Naarmate het inkomen uit bedrijf hoger wordt, ontvangen boeren dus gemiddeld een hogere inkomenstoeslag. Het aandeel van de toeslagen in het inkomen van de verschillende bedrijfstypen varieert nogal rond het EU-gemiddelde: in 2015 kwam het aandeel van de toeslag in het gezinsinkomen uit bedrijf per gezinsarbeidskracht op de vleeskoeienbedrijven en bedrijven met granen, oliezaden en eiwitgewassen boven de 100\% uit, lag het aandeel op de overige akkerbouwbedrijven, melkveebedrijven, en schapen- en geitenbedrijven rond $70 \%$, en beliep het aandeel op de intensieve veehouderijbedrijven zo'n 30\%. Omdat de landbouwinkomens van jaar tot jaar nogal kunnen fluctueren, kunnen de aandelen van de toeslagen in het landbouwinkomen van jaar tot jaar wat verschillen van elkaar. 


\section{Literatuur en websites}

EC (Europese Commissie) (2013). Regulation (EU) No 1307/2013 of the European Parliament and of the Council of 17 December 2013 establishing rules for direct payments to farmers under support schemes within the framework of the common agricultural policy and repealing Council Regulation (EC) No 637/2008 and Council Regulation (EC) No 73/2009; Brussel, Official Journal L 347/608

EC (2015). Report on the distribution of direct payments to agricultural producers (financial year 2014); Brussel

EC (2017a). De toekomst van voeding en landbouw; Brussel, Mededeling van de Commissie aan het Europees Parlement, de Raad, het Europees Economisch en Sociaal Comité En Het Comité van de Regio's, $\operatorname{COM(2017)} 713$ def

EC (2017b). Report on the distribution of direct payments to agricultural producers (financial year 2016); Brussel

Matthews, A. (2016). Focus on the distribution of direct payments; Via website: http://capreform. eu/focus-on-the-distribution-of-direct-payments/

Meulen, H.A.B van, A.B. Smit en J.H. Jager (2017). Effecten van het GLB op inkomens, kosten en administratieve lasten; Wageningen, Wageningen Economic research, Rapport 2017-080

Strijker, D. (2017). Smal en gefocust; Een essay over het toekomstige Europese Landbouwbeleid; Groningen, RUG, URSI Research Report 359

Terluin, I., T. Kuhmonen en P. Berkhout (2017). Flexibility given to Member States in CAP implementation: state of play and perspectives; Brussel, European Parliament, Policy Department for Structural and Cohesion Policies, Research for AGRI Committee

Vogelzang, T., P. Berkhout, A. van Doorn, R. Jongeneel, K. Poppe, B. Smit en I. Terluin (2016). Het GLB na 2020; Schets voor een herontwerp; Den Haag, LEI-rapport 2016-009 


\section{Bijlage 1 Fictieve verdeling van de toeslagen op basis van een uniforme hectarepremie over bedrijven in de EU-lidstaten}

Distribution of direct payments based on a uniform hectare payment over farms in Belgium

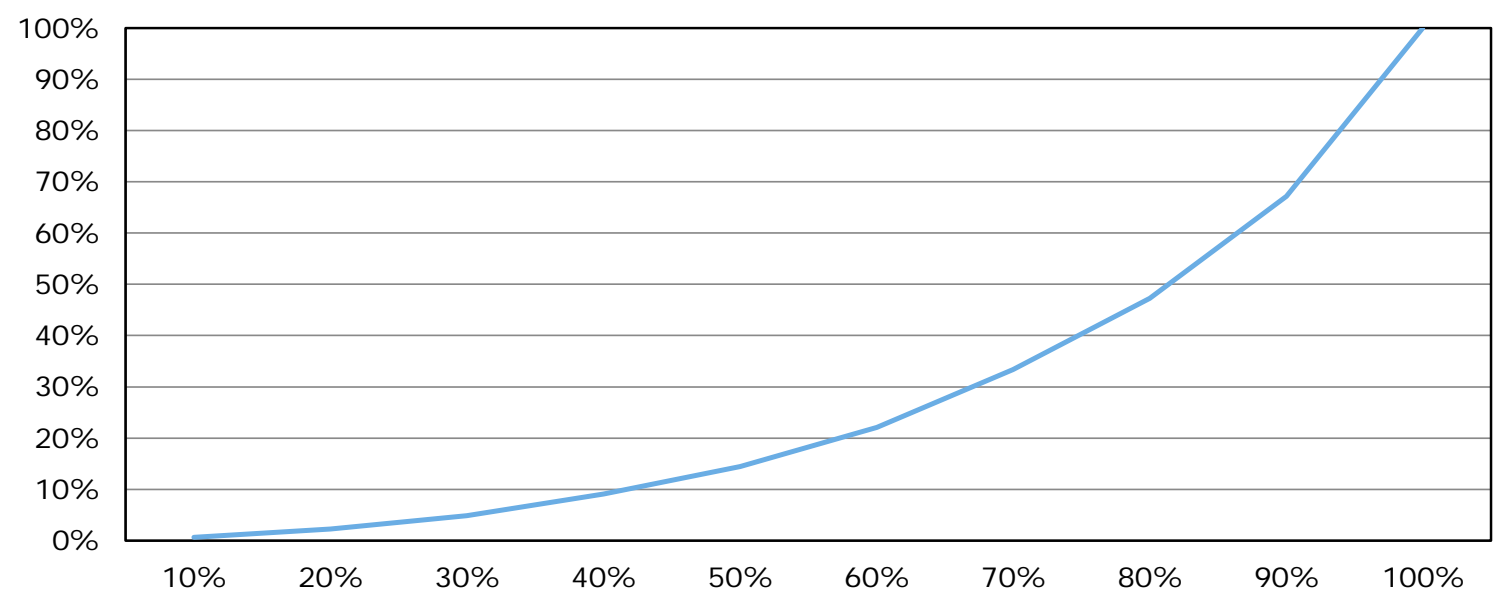

Figuur B1.1 Fictieve verdeling van de toeslagen op basis van een uniforme hectarepremie over bedrijven in België, 2015

Bron: EC (2013) en Eurostat Farm Structure Survey (FSS); bewerking Wageningen Economic Research.

Distribution of direct payments based on a uniform hectare payment over farms in Bulgaria

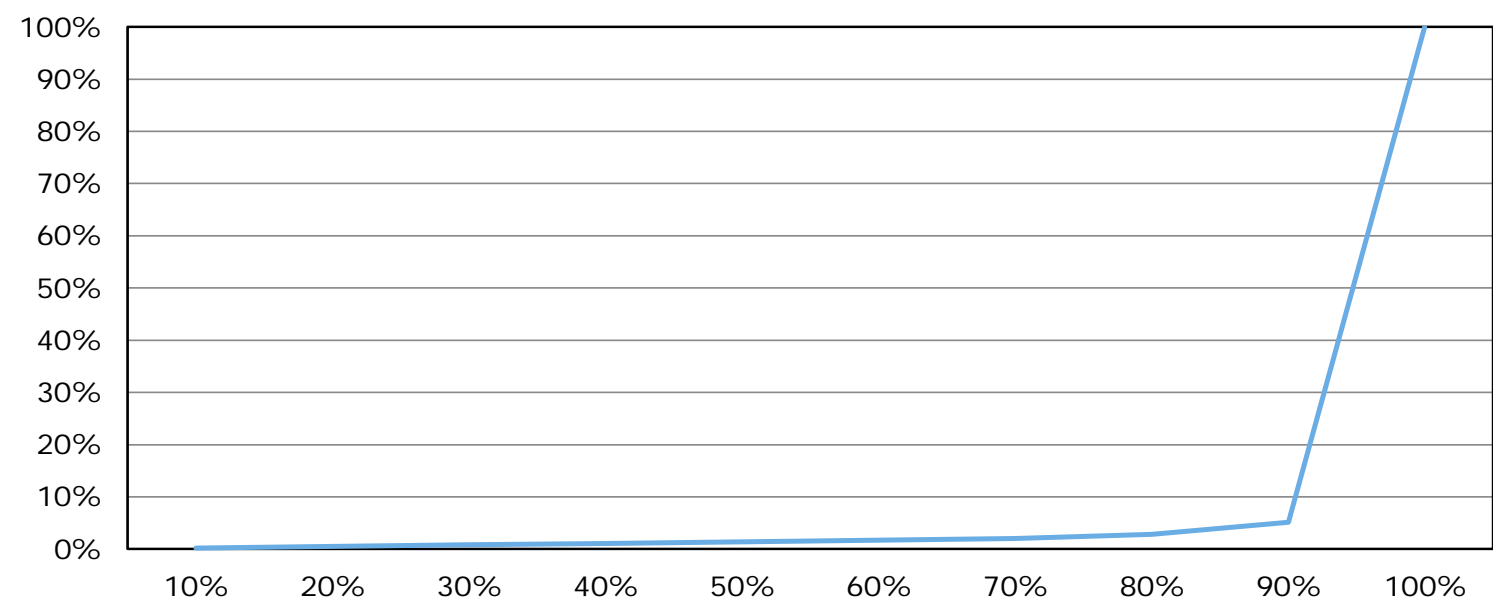

Figuur B1.2 Fictieve verdeling van de toeslagen op basis van een uniforme hectarepremie over bedrijven in Bulgarije, 2015

Bron: EC (2013) en Eurostat Farm Structure Survey (FSS); bewerking Wageningen Economic Research. 


\section{Distribution of direct payments based on a uniform hectare payment}

over farms in Czech Republic

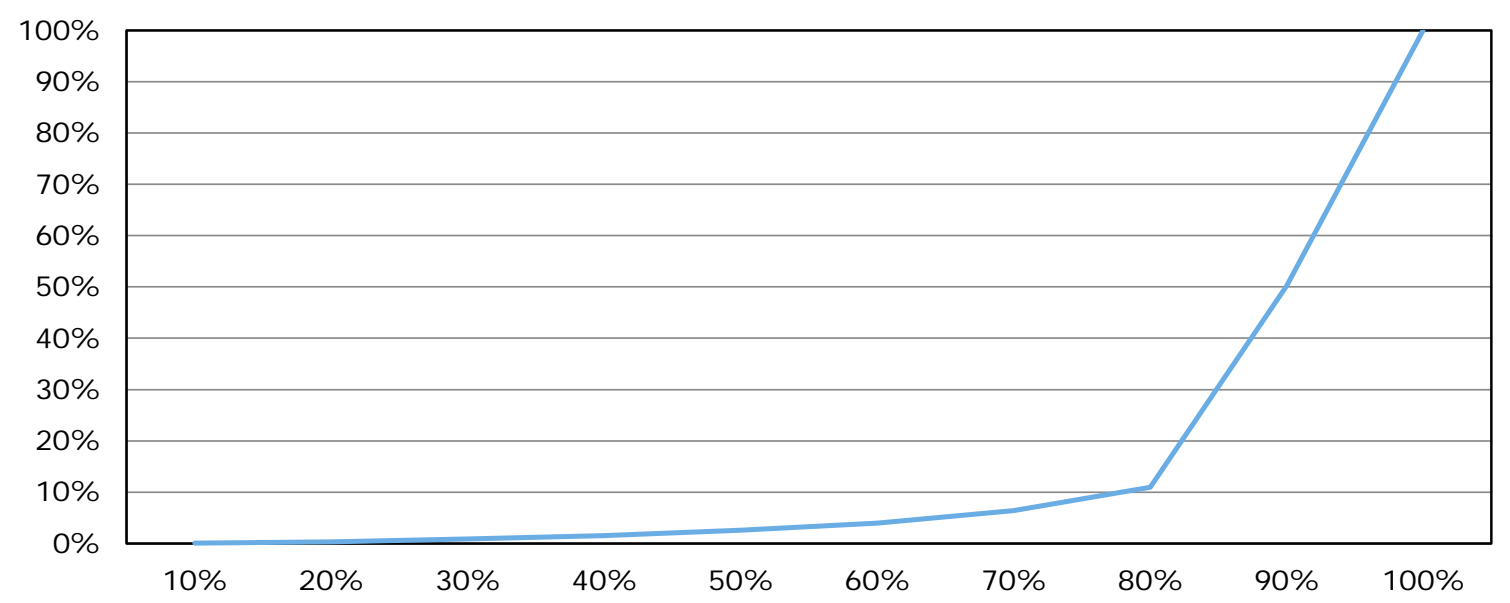

Figuur B1.3 Fictieve verdeling van de toeslagen op basis van een uniforme hectarepremie over bedrijven in Tsjechië, 2015

Bron: EC (2013) en Eurostat Farm Structure Survey (FSS); bewerking Wageningen Economic Research.

Distribution of direct payments based on a uniform hectare payment over farms in Denmark

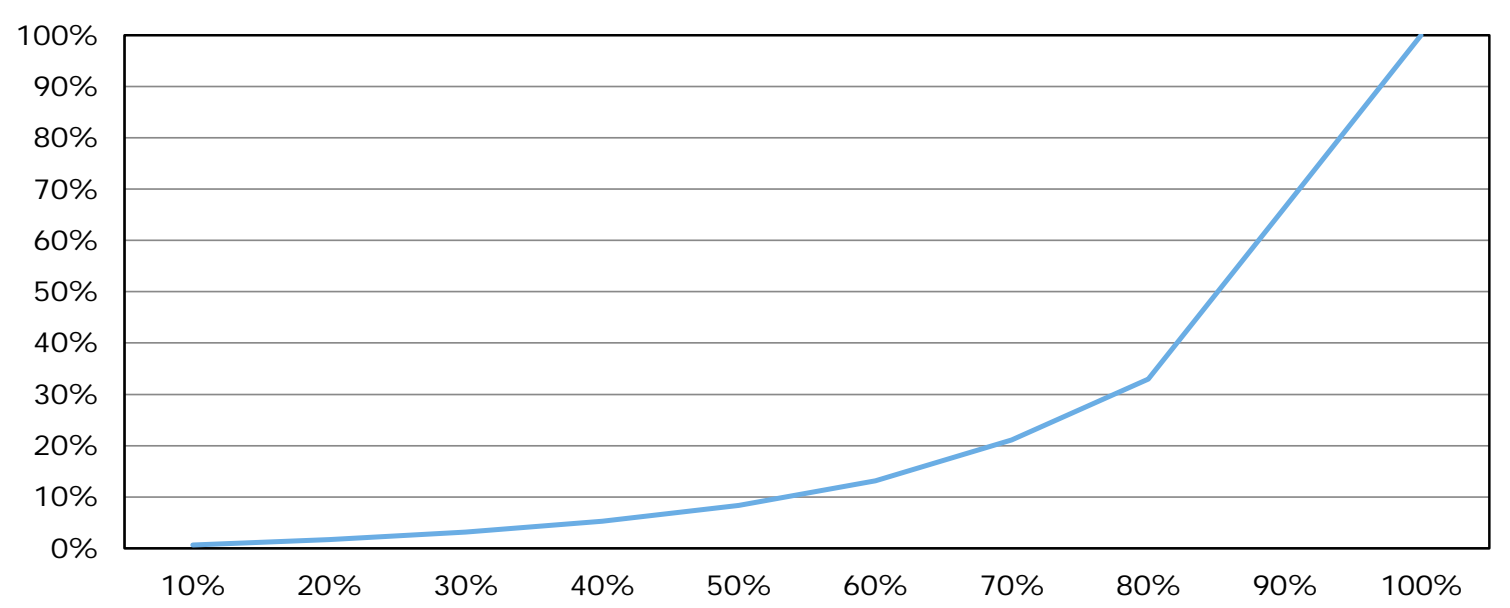

Figuur B1.4 Fictieve verdeling van de toeslagen op basis van een uniforme hectarepremie over bedrijven in Denemarken 2015

Bron: EC (2013) en Eurostat Farm Structure Survey (FSS); bewerking Wageningen Economic Research. 


\section{Distribution of direct payments based on a uniform hectare payment}

over farms in Germany

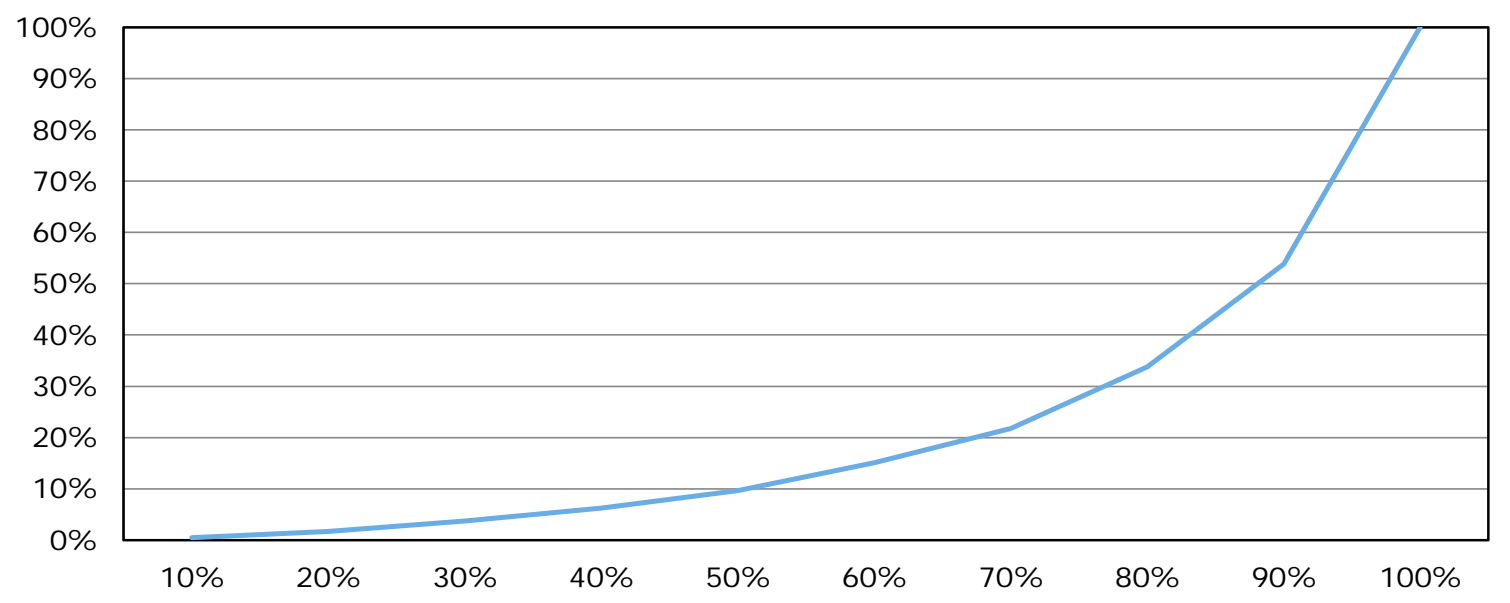

Figuur B1.5 Fictieve verdeling van de toeslagen op basis van een uniforme hectarepremie over bedrijven in Duitsland, 2015

Bron: EC (2013) en Eurostat Farm Structure Survey (FSS); bewerking Wageningen Economic Research.

Distribution of direct payments based on a uniform hectare payment over farms in Estonia

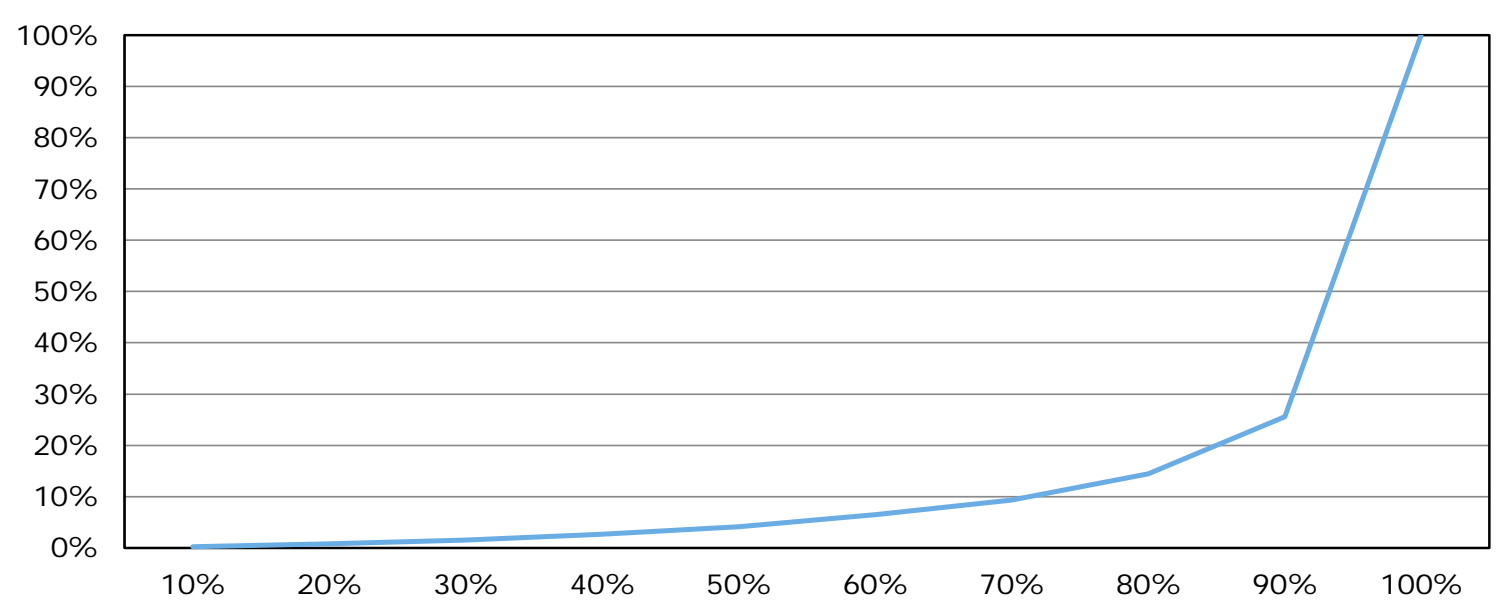

Figuur B1.6 Fictieve verdeling van de toeslagen op basis van een uniforme hectarepremie over bedrijven in Estland, 2015

Bron: EC (2013) en Eurostat Farm Structure Survey (FSS); bewerking Wageningen Economic Research. 
Distribution of direct payments based on a uniform hectare payment over farms in Ireland

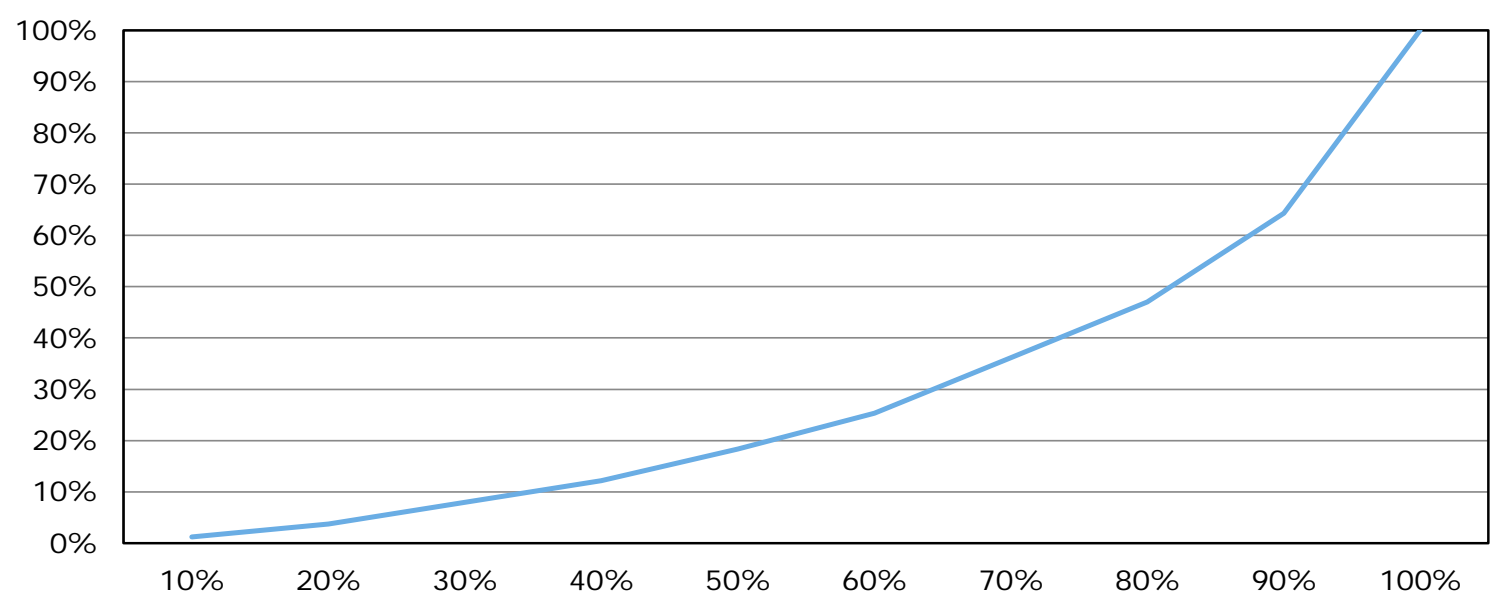

Figuur B1.7 Fictieve verdeling van de toeslagen op basis van een uniforme hectarepremie over bedrijven in lerland, 2015

Bron: EC (2013) en Eurostat Farm Structure Survey (FSS); bewerking Wageningen Economic Research.

Distribution of direct payments based on a uniform hectare payment over farms in Greece

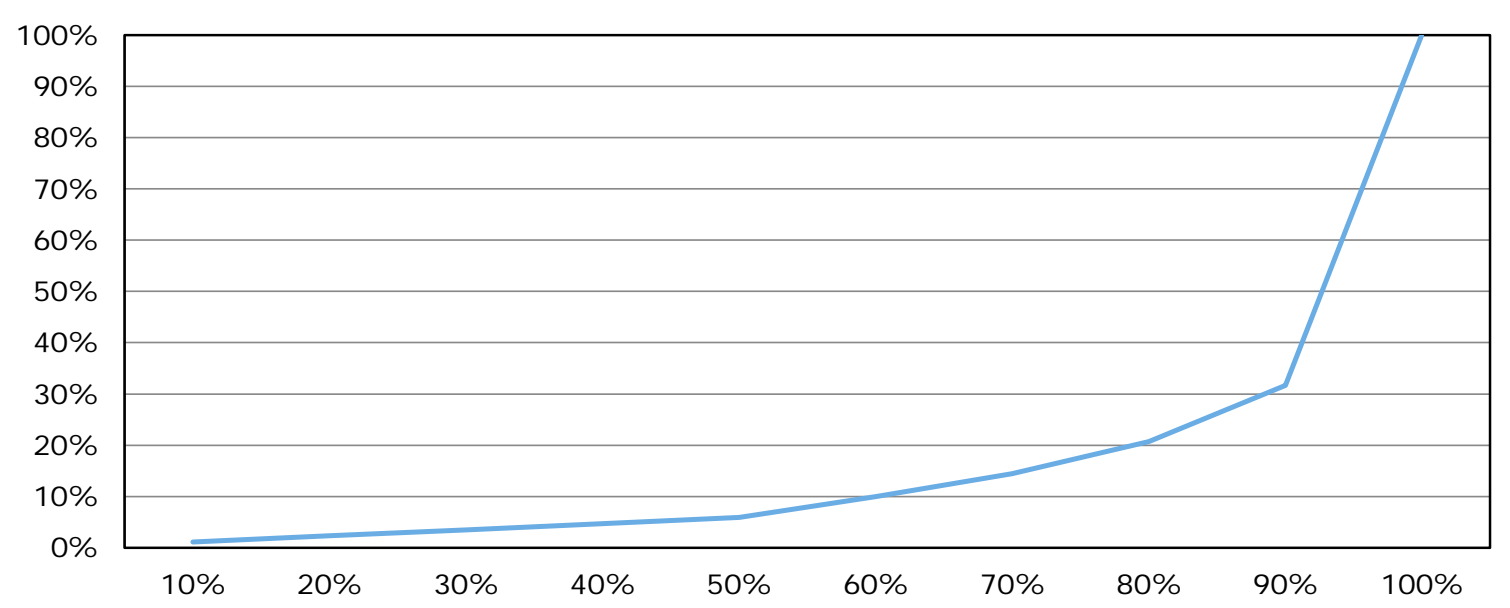

Figuur B1.8 Fictieve verdeling van de toeslagen op basis van een uniforme hectarepremie over bedrijven in Griekenland, 2015

Bron: EC (2013) en Eurostat Farm Structure Survey (FSS); bewerking Wageningen Economic Research. 


\section{Distribution of direct payments based on a uniform hectare payment}

over farms in Spain

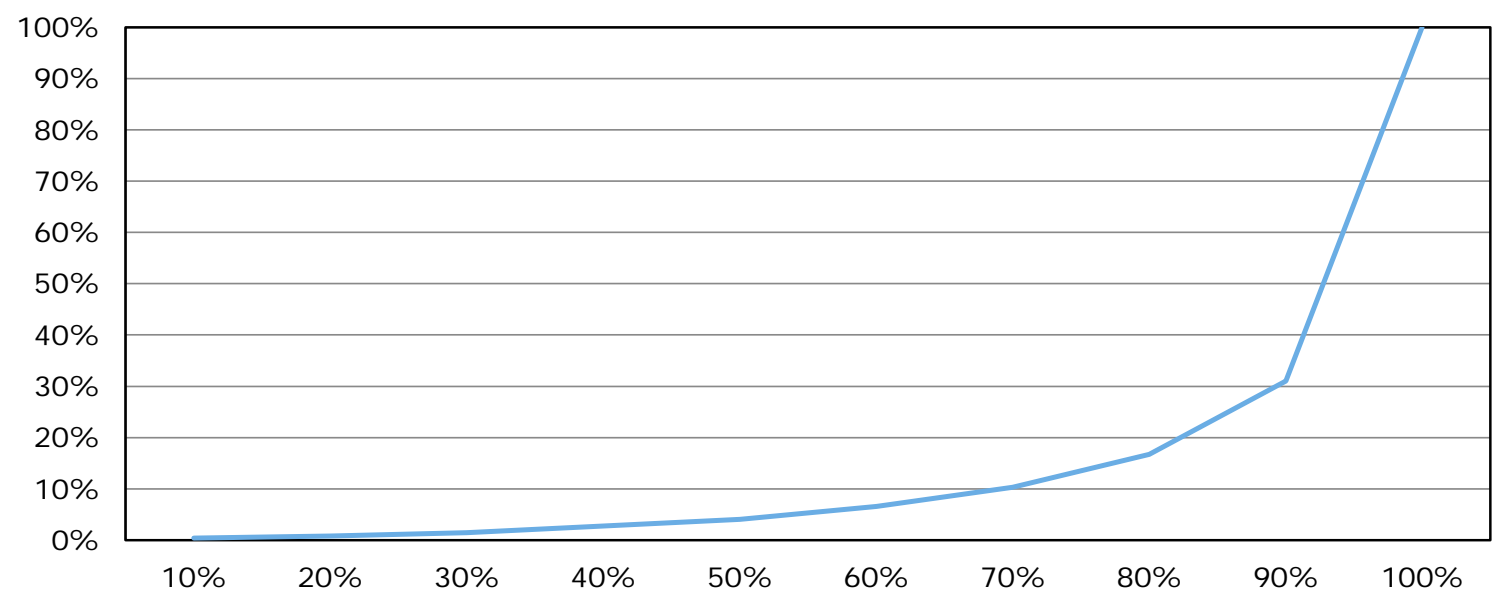

Figuur B1.9 Fictieve verdeling van de toeslagen op basis van een uniforme hectarepremie over bedrijven in Spanje, 2015

Bron: EC (2013) en Eurostat Farm Structure Survey (FSS); bewerking Wageningen Economic Research.

Distribution of direct payments based on a uniform hectare payment over farms in France

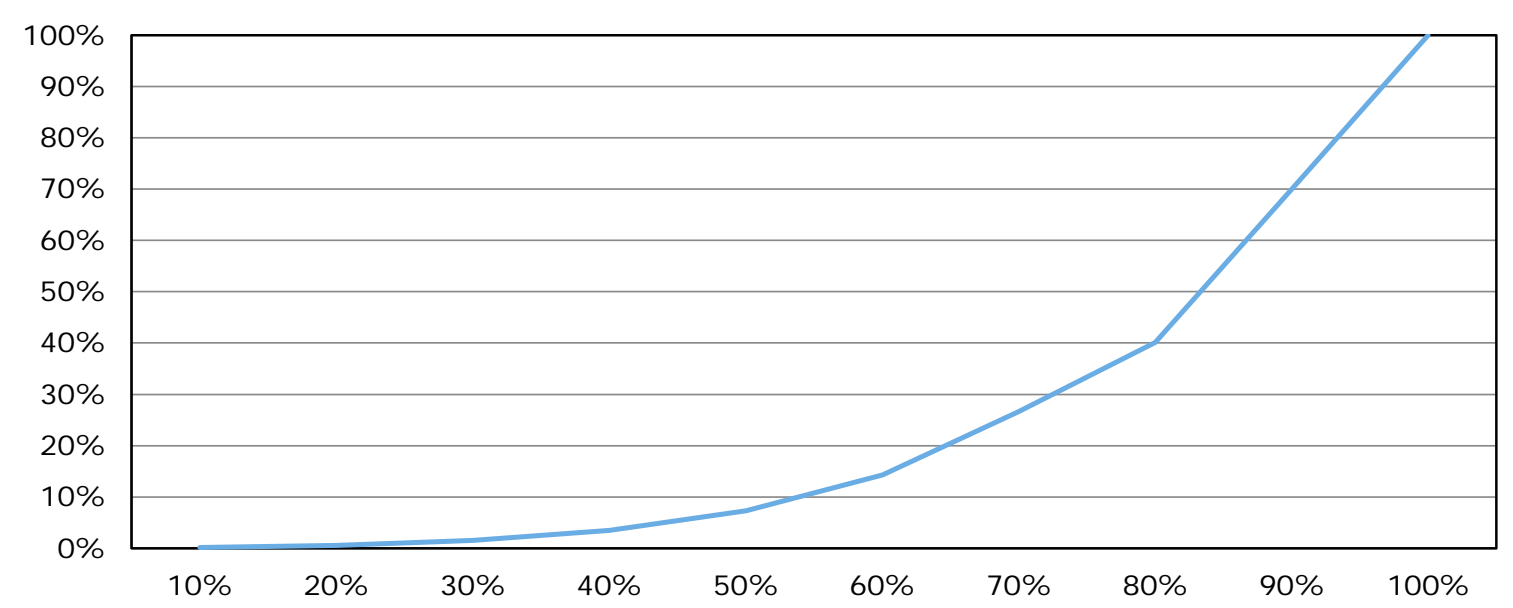

Figuur B1.10 Fictieve verdeling van de toeslagen op basis van een uniforme hectarepremie over bedrijven in Frankrijk, 2015

Bron: EC (2013) en Eurostat Farm Structure Survey (FSS); bewerking Wageningen Economic Research. 


\section{Distribution of direct payments based on a uniform hectare payment}

over farms in Croatia

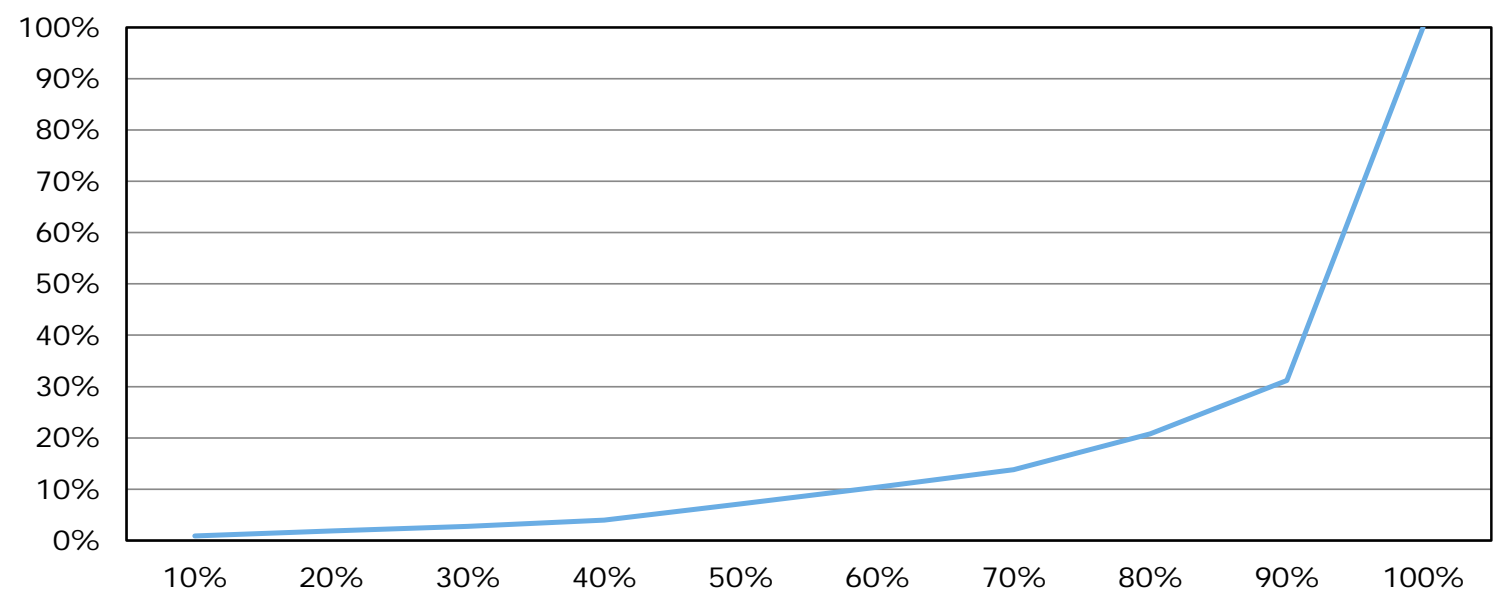

Figuur B1.11 Fictieve verdeling van de toeslagen op basis van een uniforme hectarepremie over bedrijven in Kroatië, 2015

Bron: EC (2013) en Eurostat Farm Structure Survey (FSS); bewerking Wageningen Economic Research.

Distribution of direct payments based on a uniform hectare payment over farms in Italy

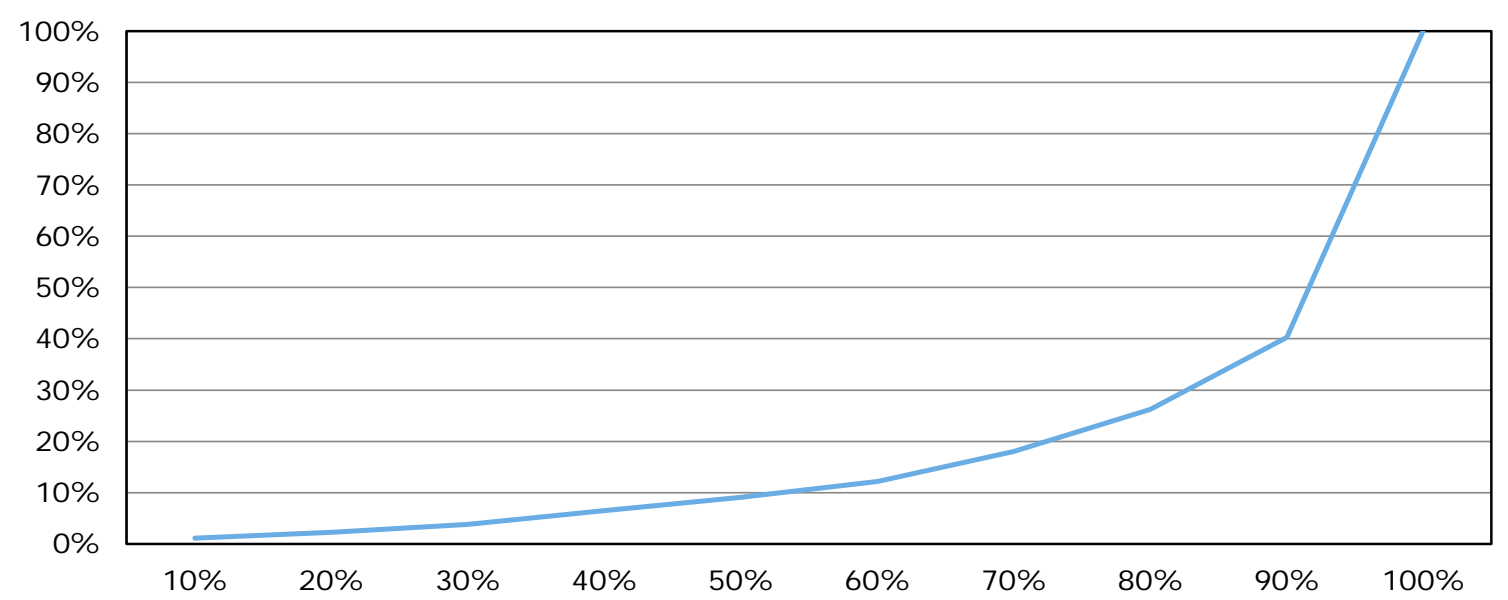

Figuur B1.12 Fictieve verdeling van de toeslagen op basis van een uniforme hectarepremie over bedrijven in Italië, 2015

Bron: EC (2013) en Eurostat Farm Structure Survey (FSS); bewerking Wageningen Economic Research. 


\section{Distribution of direct payments based on a uniform hectare payment}

over farms in Cyprus

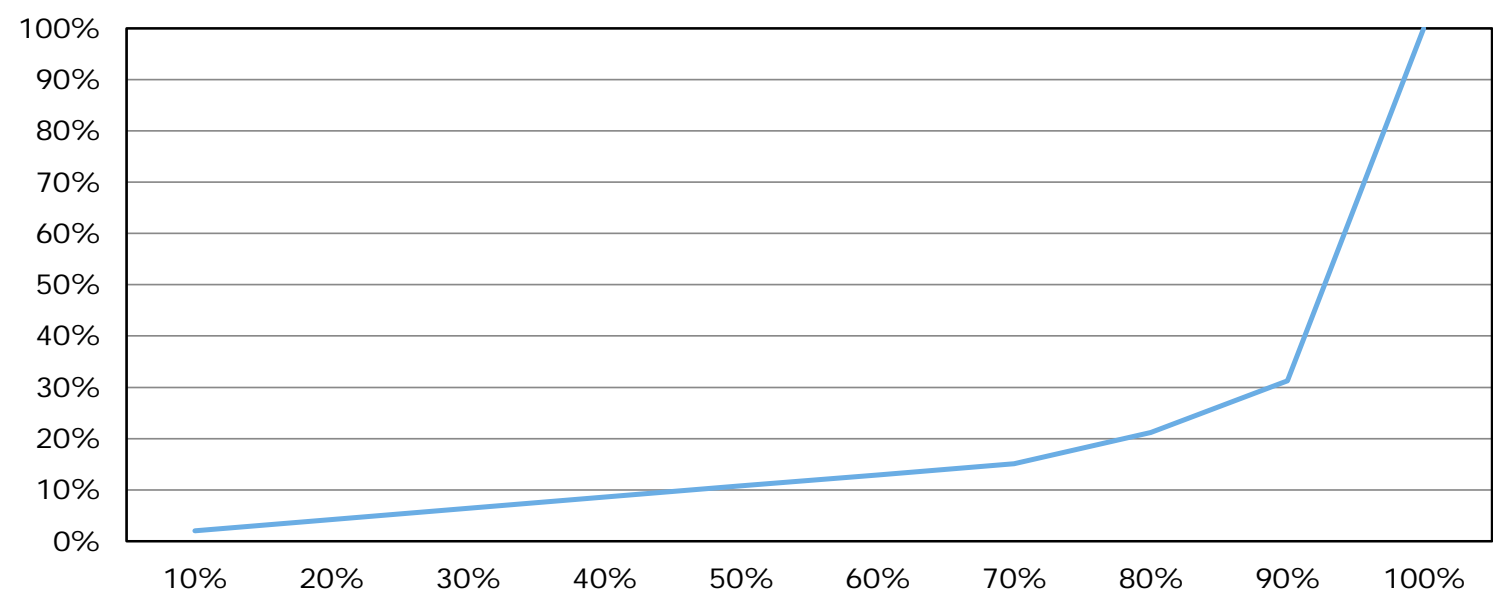

Figuur B1.13 Fictieve verdeling van de toeslagen op basis van een uniforme hectarepremie over bedrijven op Cyprus, 2015

Bron: EC (2013) en Eurostat Farm Structure Survey (FSS); bewerking Wageningen Economic Research.

Distribution of direct payments based on a uniform hectare payment over farms in Latvia

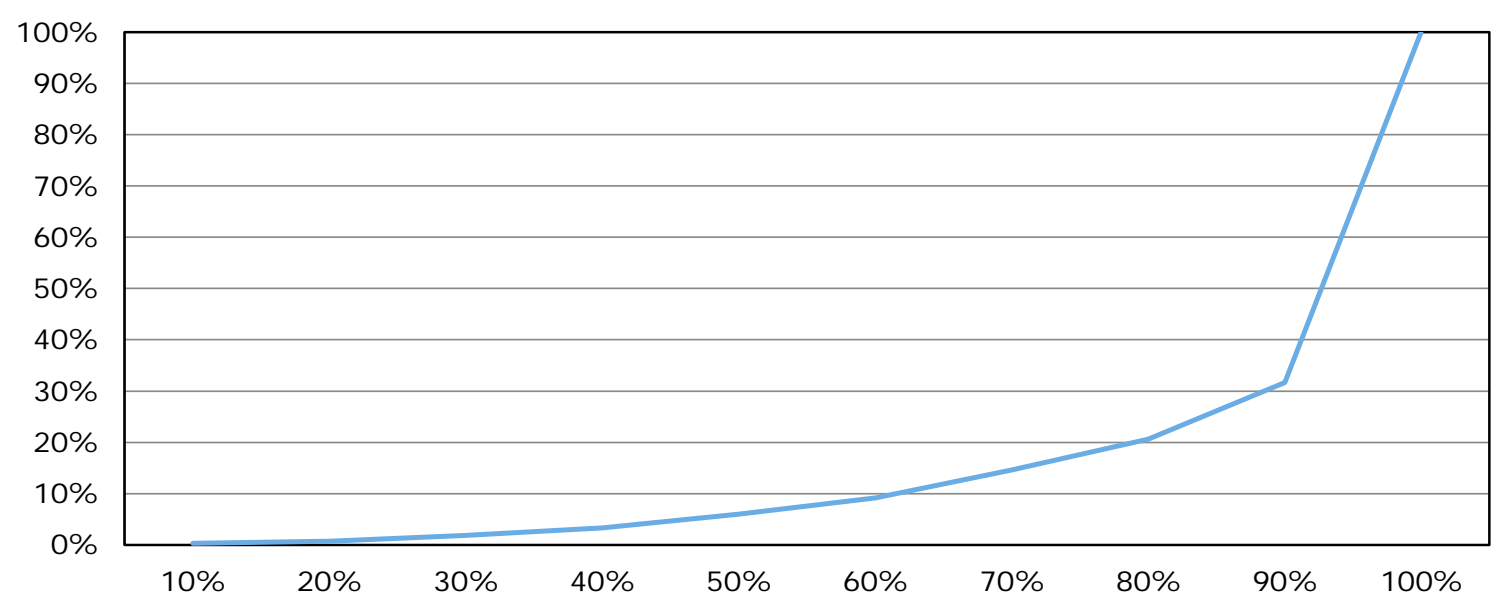

Figuur B1.14 Fictieve verdeling van de toeslagen op basis van een uniforme hectarepremie over bedrijven in Letland, 2015

Bron: EC (2013) en Eurostat Farm Structure Survey (FSS); bewerking Wageningen Economic Research. 


\section{Distribution of direct payments based on a uniform hectare payment}

over farms in Lithuania

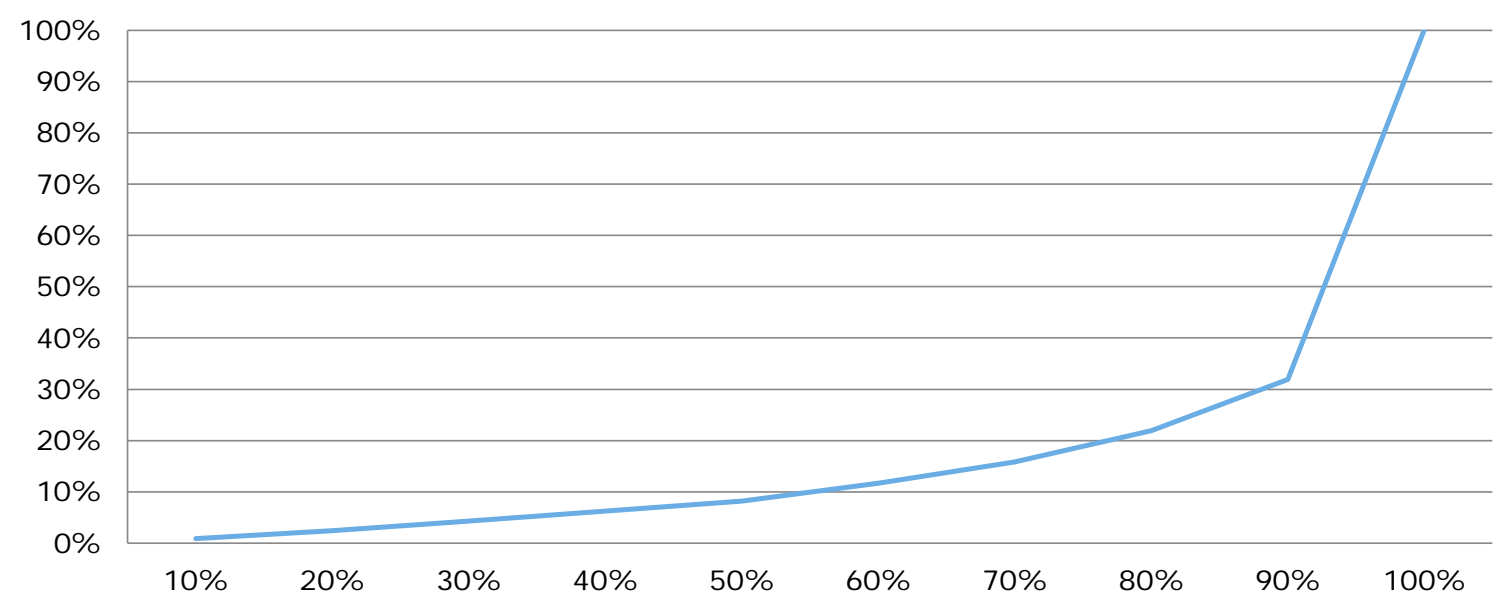

Figuur B1.15 Fictieve verdeling van de toeslagen op basis van een uniforme hectarepremie over bedrijven in Litouwen, 2015

Bron: EC (2013) en Eurostat Farm Structure Survey (FSS); bewerking Wageningen Economic Research.

Distribution of direct payments based on a uniform hectare payment over farms in Luxembourg

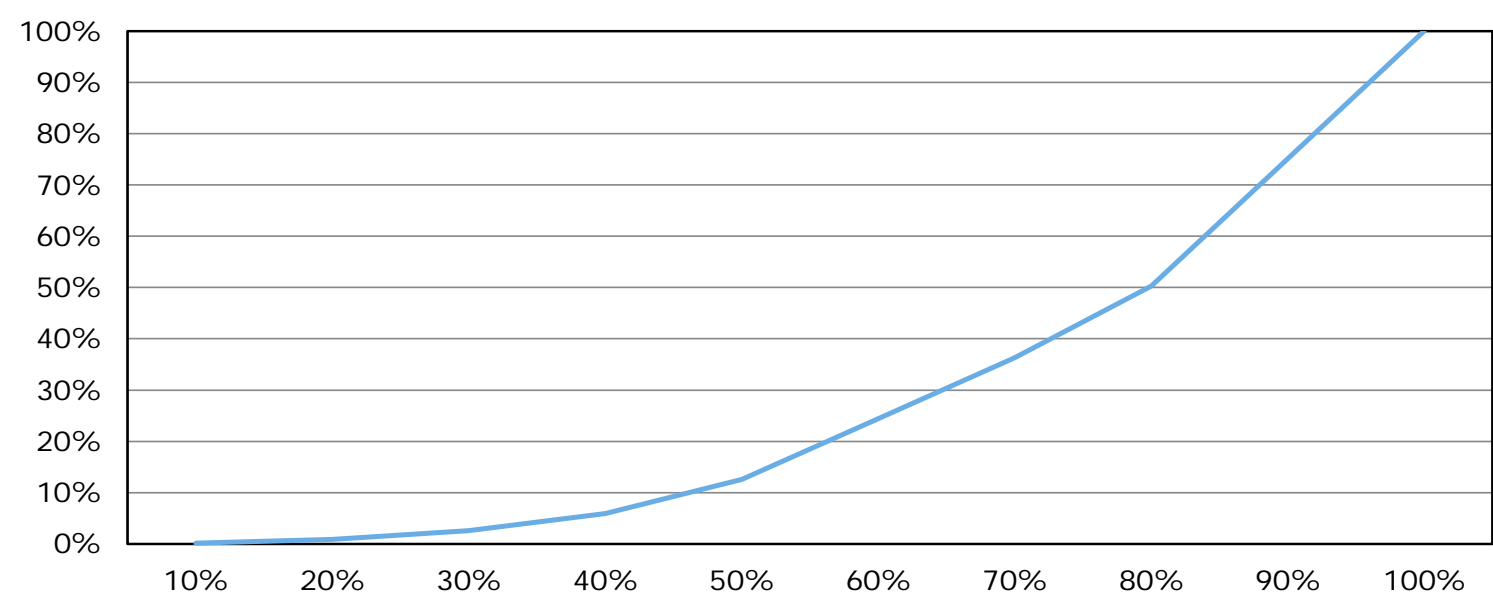

Figuur B1.16 Fictieve verdeling van de toeslagen op basis van een uniforme hectarepremie over bedrijven in Luxemburg, 2015

Bron: EC (2013) en Eurostat Farm Structure Survey (FSS); bewerking Wageningen Economic Research. 


\section{Distribution of direct payments based on a uniform hectare payment}

over farms in Hungary

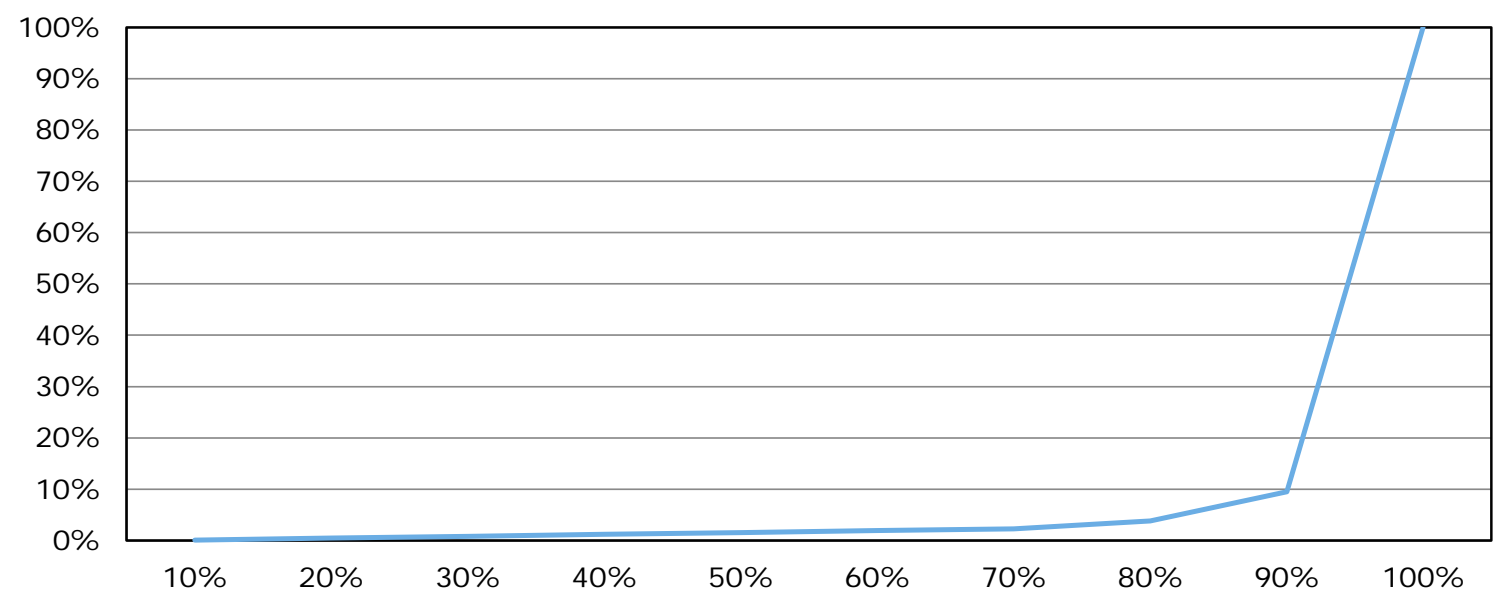

Figuur B1.17 Fictieve verdeling van de toeslagen op basis van een uniforme hectarepremie over bedrijven in Hongarije, 2015

Bron: EC (2013) en Eurostat Farm Structure Survey (FSS); bewerking Wageningen Economic Research.

Distribution of direct payments based on a uniform hectare payment over farms in Malta

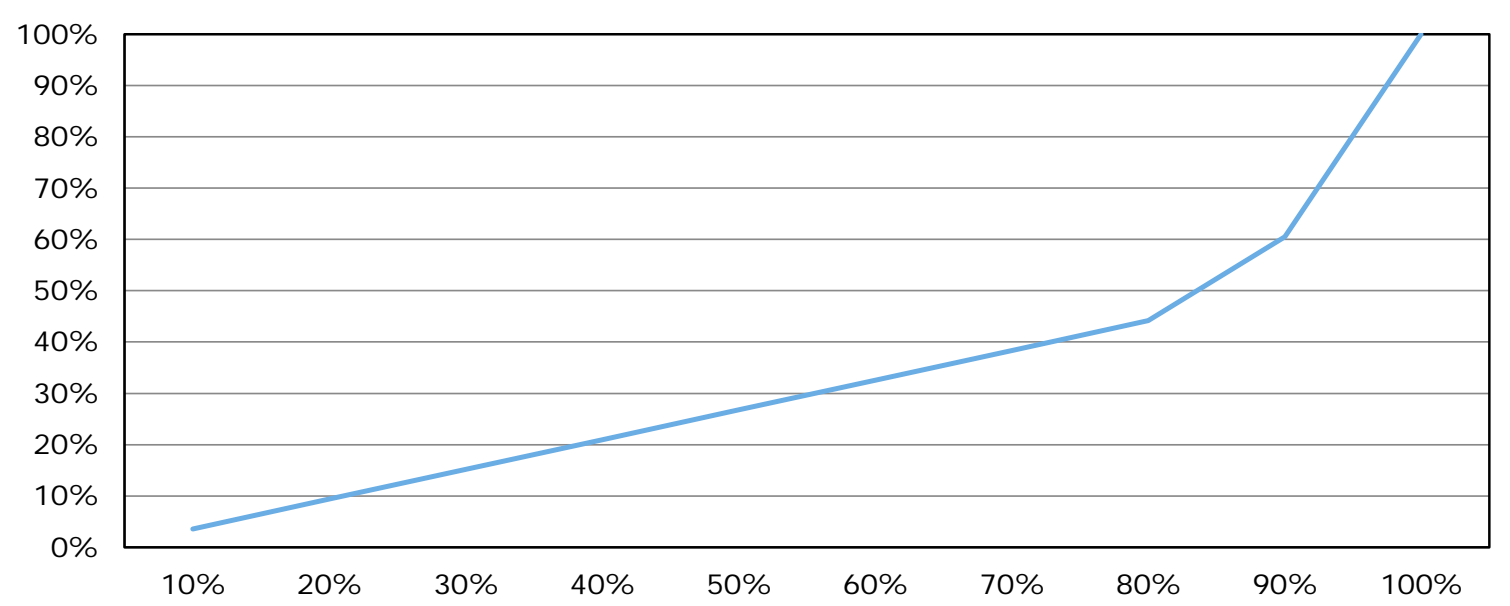

Figuur B1.18 Fictieve verdeling van de toeslagen op basis van een uniforme hectarepremie over bedrijven op Malta, 2015

Bron: EC (2013) en Eurostat Farm Structure Survey (FSS); bewerking Wageningen Economic Research. 


\section{Distribution of direct payments based on a uniform hectare payment}

over farms in Netherlands

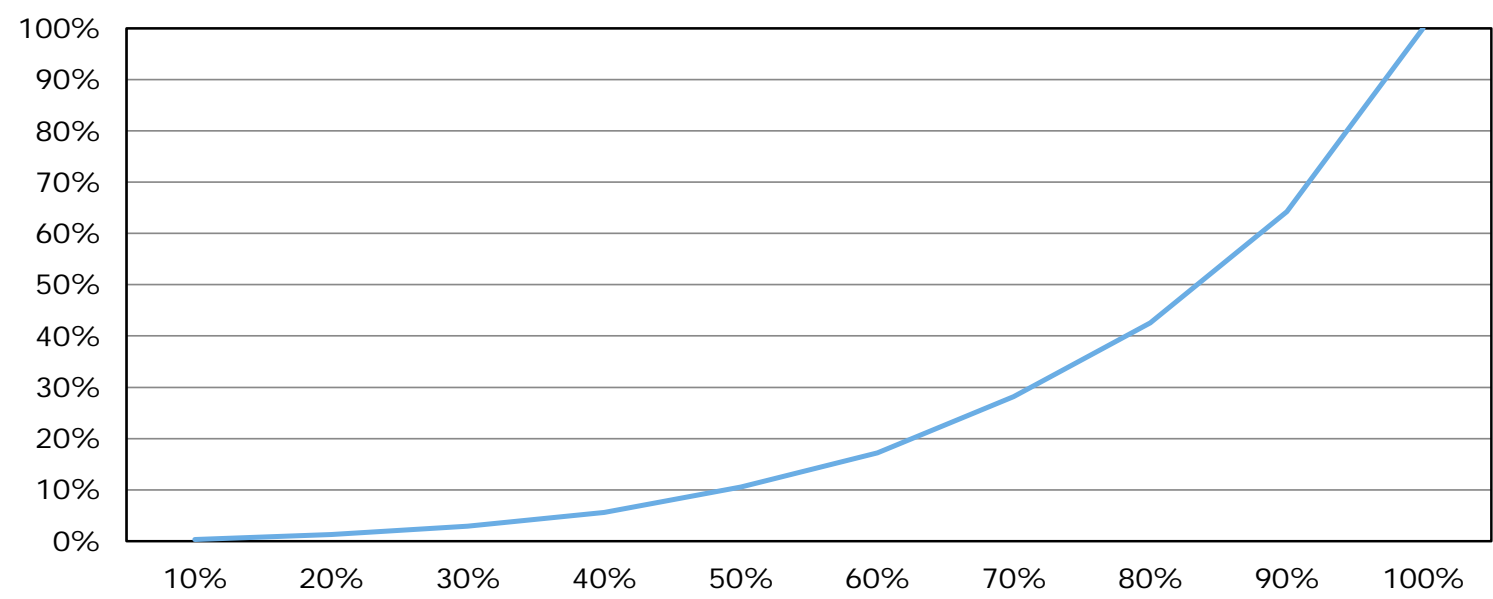

Figuur B1.19 Fictieve verdeling van de toeslagen op basis van een uniforme hectarepremie over bedrijven in Nederland, 2015

Bron: EC (2013) en Eurostat Farm Structure Survey (FSS); bewerking Wageningen Economic Research.

Distribution of direct payments based on a uniform hectare payment over farms in Austria

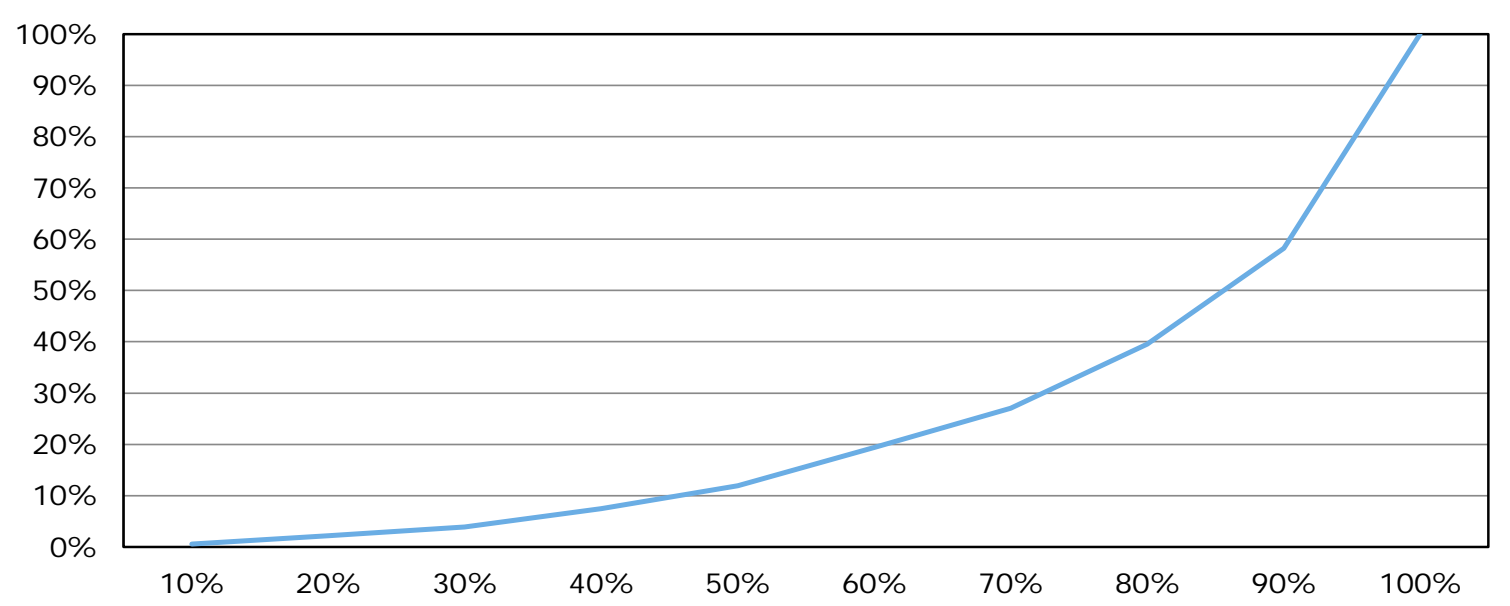

Figuur B1.20 Fictieve verdeling van de toeslagen op basis van een uniforme hectarepremie over bedrijven in Oostenrijk, 2015

Bron: EC (2013) en Eurostat Farm Structure Survey (FSS); bewerking Wageningen Economic Research. 


\section{Distribution of direct payments based on a uniform hectare payment}

over farms in Poland

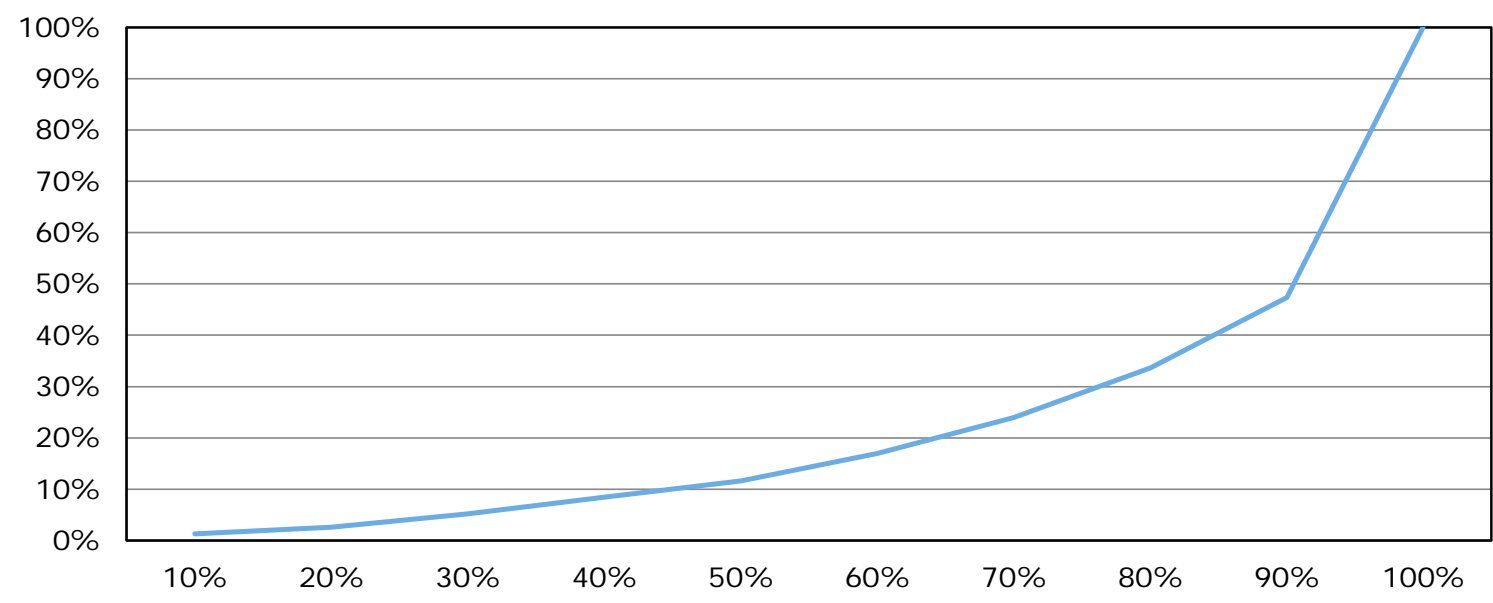

Figuur B1.21 Fictieve verdeling van de toeslagen op basis van een uniforme hectarepremie over bedrijven in Polen, 2015

Bron: EC (2013) en Eurostat Farm Structure Survey (FSS); bewerking Wageningen Economic Research.

Distribution of direct payments based on a uniform hectare payment over farms in Portugal

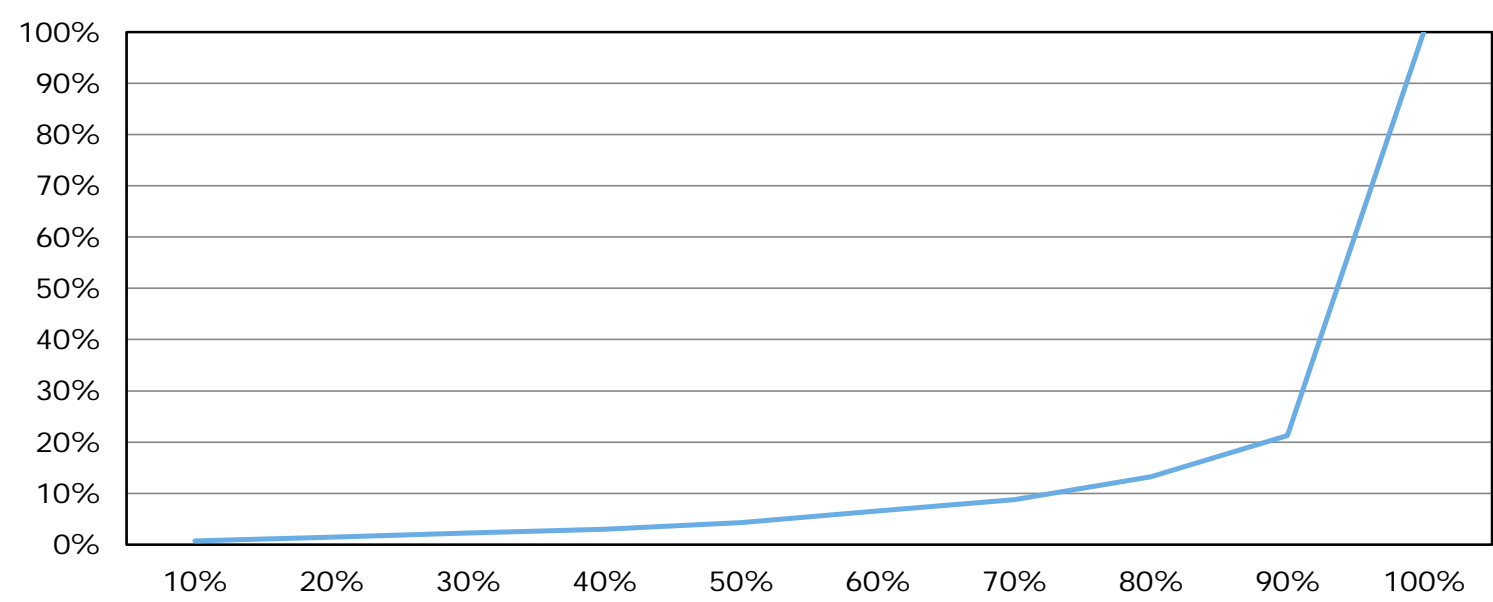

Figuur B1.22 Fictieve verdeling van de toeslagen op basis van een uniforme hectarepremie over bedrijven in Portugal, 2015

Bron: EC (2013) en Eurostat Farm Structure Survey (FSS); bewerking Wageningen Economic Research. 


\section{Distribution of direct payments based on a uniform hectare payment}

over farms in Romania

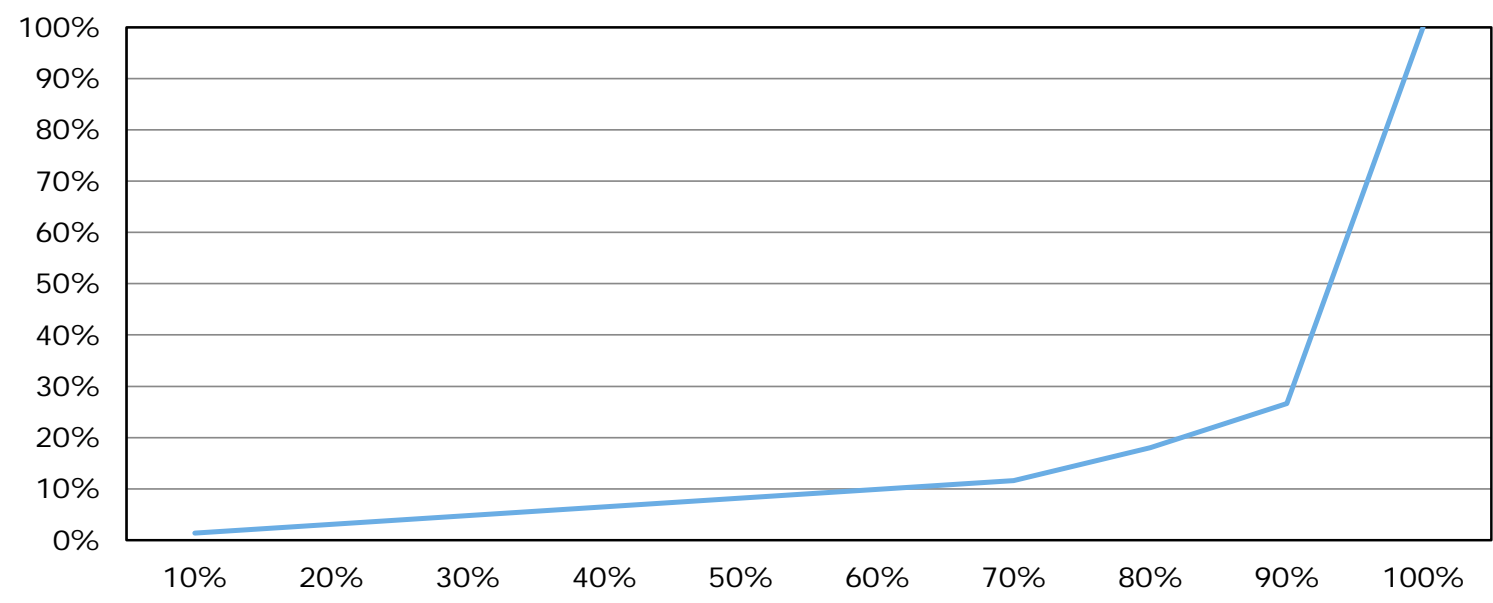

Figuur B1.23 Fictieve verdeling van de toeslagen op basis van een uniforme hectarepremie over bedrijven in Roemenië, 2015

Bron: EC (2013) en Eurostat Farm Structure Survey (FSS); bewerking Wageningen Economic Research.

Distribution of direct payments based on a uniform hectare payment over farms in Slovenia

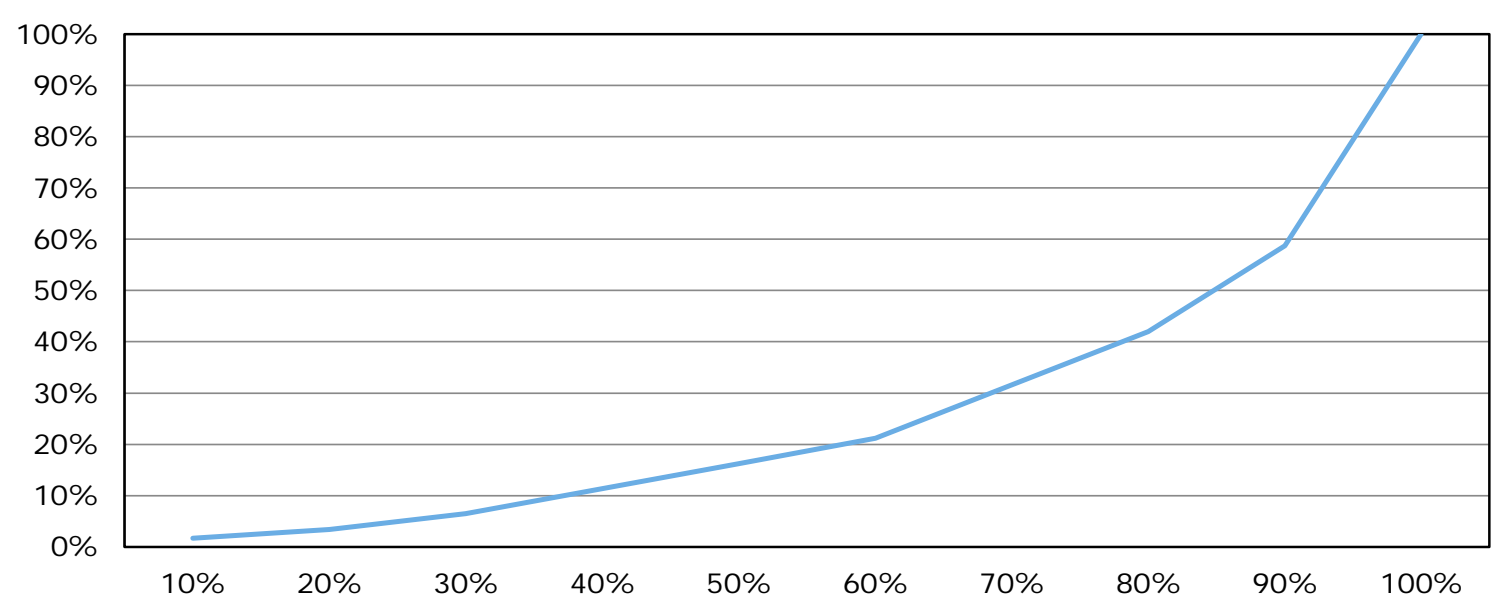

Figuur B1.24 Fictieve verdeling van de toeslagen op basis van een uniforme hectarepremie over bedrijven in Slovenië, 2015

Bron: EC (2013) en Eurostat Farm Structure Survey (FSS); bewerking Wageningen Economic Research. 


\section{Distribution of direct payments based on a uniform hectare payment}

over farms in Slovakia

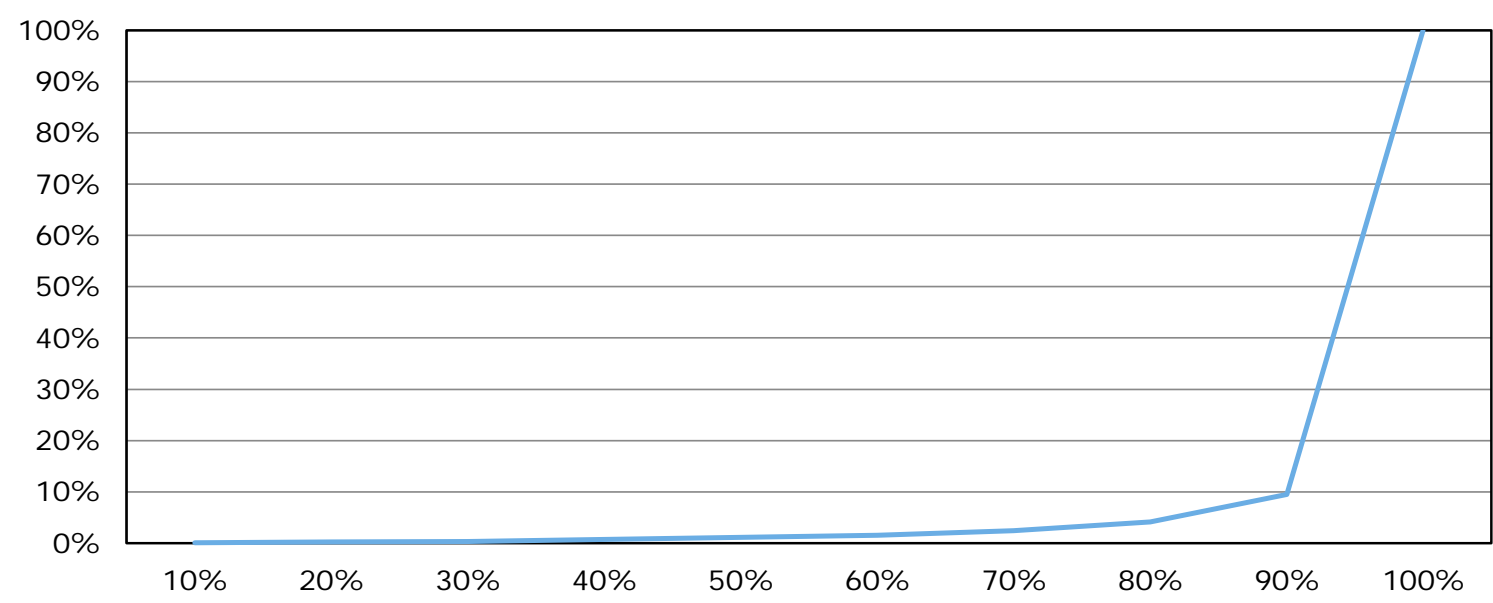

Figuur B1.25 Fictieve verdeling van de toeslagen op basis van een uniforme hectarepremie over bedrijven in Slowakije, 2015

Bron: EC (2013) en Eurostat Farm Structure Survey (FSS); bewerking Wageningen Economic Research.

Distribution of direct payments based on a uniform hectare payment over farms in Finland

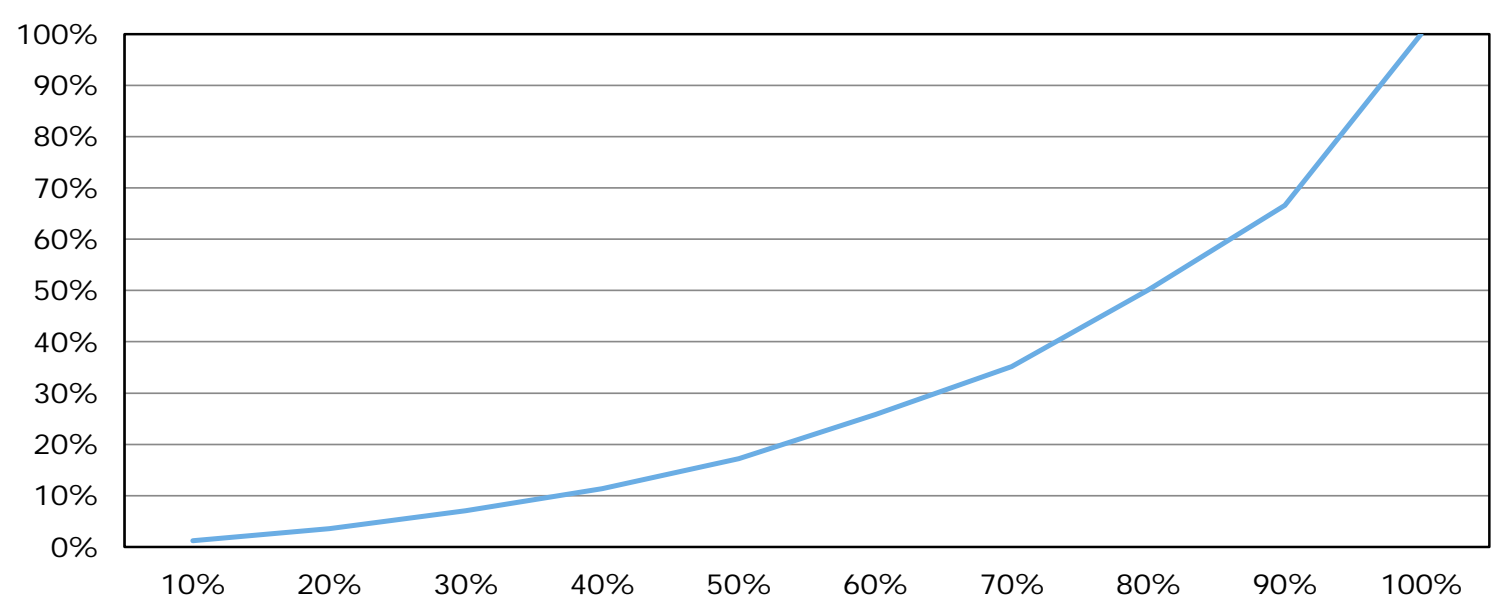

Figuur B1.26 Fictieve verdeling van de toeslagen op basis van een uniforme hectarepremie over bedrijven in Finland, 2015

Bron: EC (2013) en Eurostat Farm Structure Survey (FSS); bewerking Wageningen Economic Research. 


\section{Distribution of direct payments based on a uniform hectare payment}

over farms in Sweden

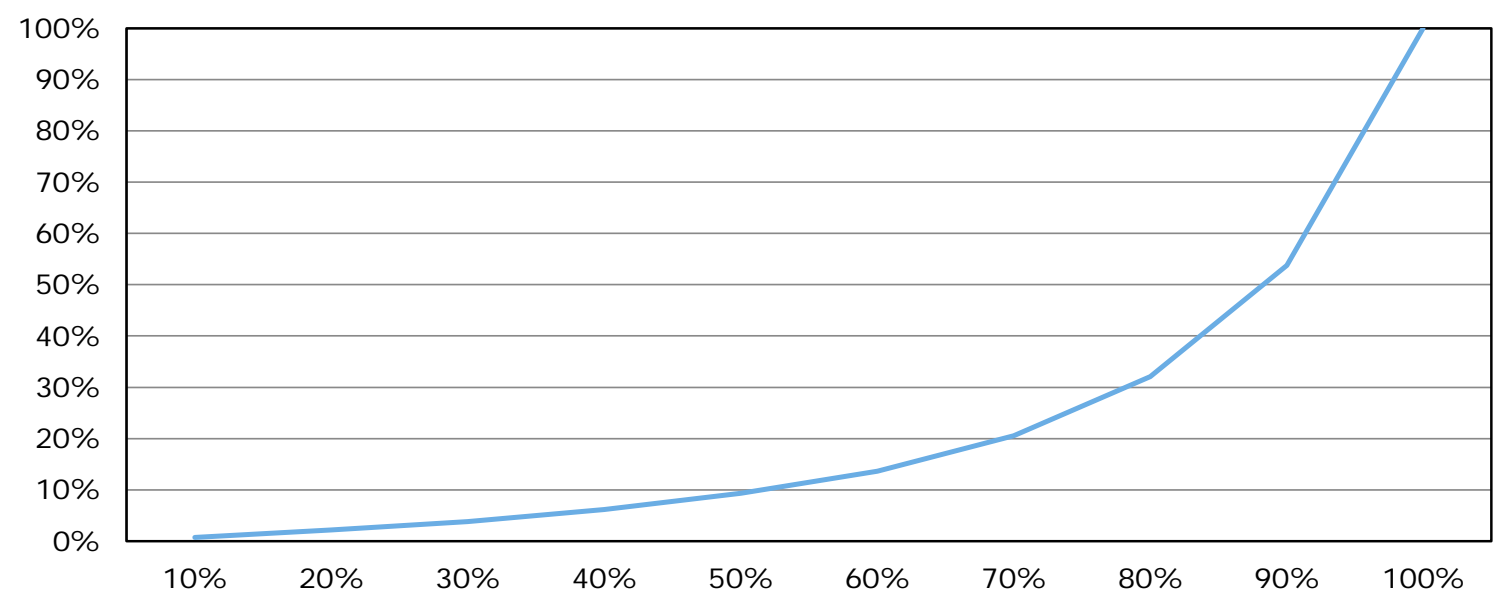

Figuur B1.27 Fictieve verdeling van de toeslagen op basis van een uniforme hectarepremie over bedrijven in Zweden, 2015

Bron: EC (2013) en Eurostat Farm Structure Survey (FSS); bewerking Wageningen Economic Research.

Distribution of direct payments based on a uniform hectare payment over farms in United Kingdom

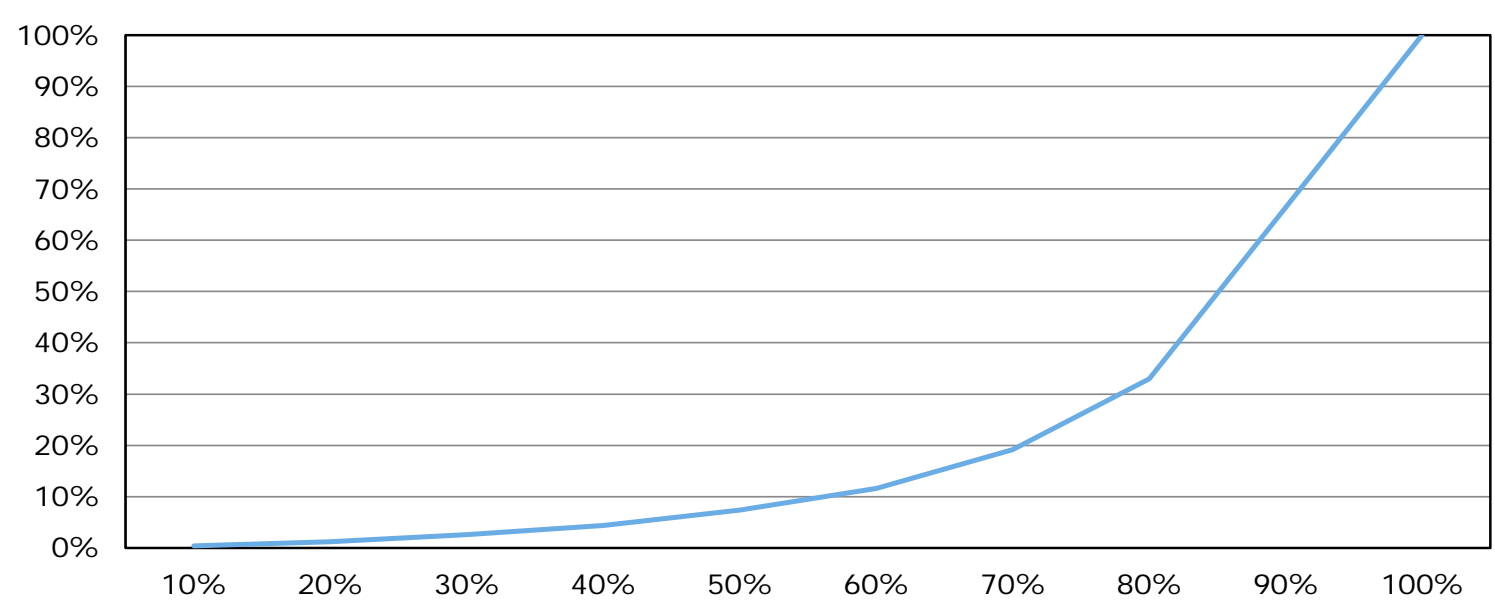

Figuur B1.28 Fictieve verdeling van de toeslagen op basis van een uniforme hectarepremie over bedrijven in het VK, 2015

Bron: EC (2013) en Eurostat Farm Structure Survey (FSS); bewerking Wageningen Economic Research. 


\section{Bijlage 2 Inkomenstoeslagen uit de eerste pijler van het GLB in het inkomen per bedrijfstype in de EU-lidstaten, 2015}

Share of P1 payments in family farm income per FWU in Belgium (2015)

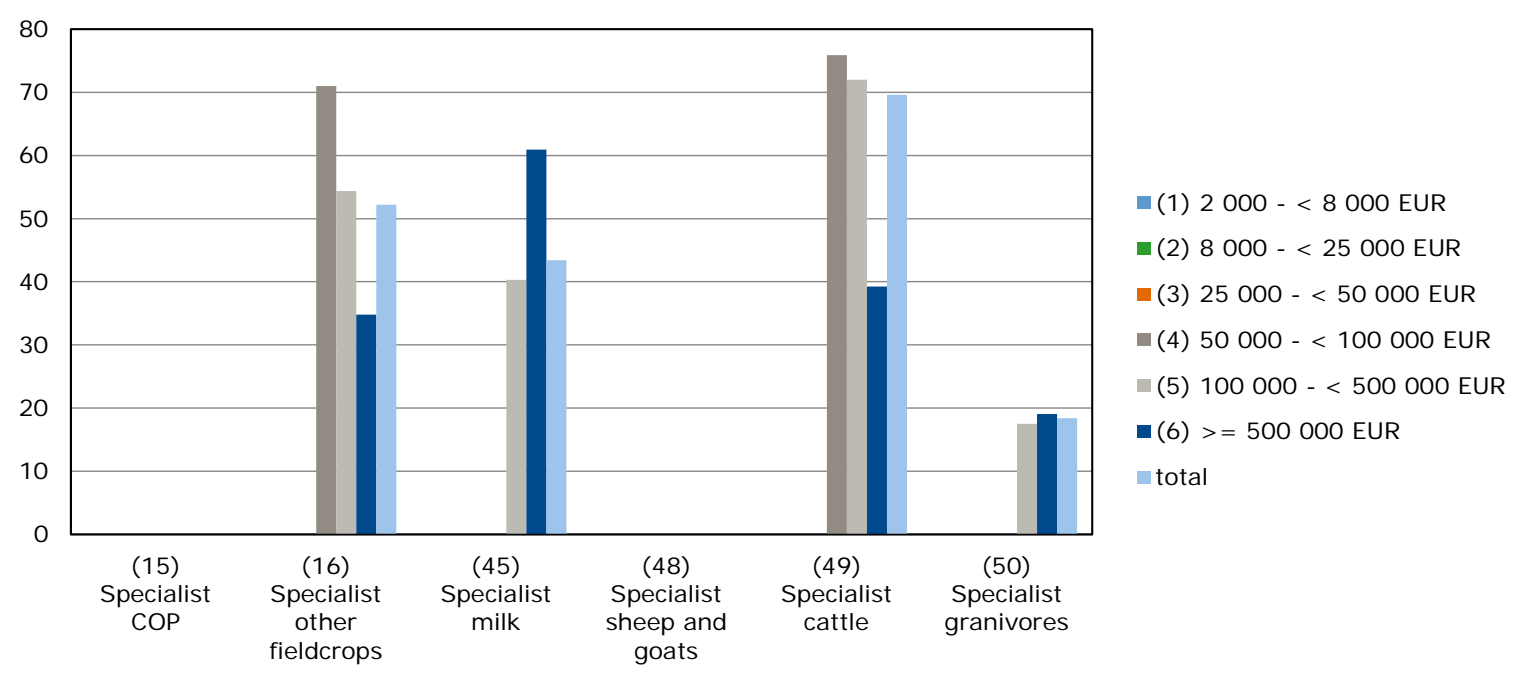

Figuur B2.1 Aandeel van de inkomenstoeslagen van de eerste pijler van het GLB in het gezinsinkomen uit bedrijf per gezinsarbeidskracht op de verschillende bedrijfstypen in België, 2015 Toelichting: een ontbrekend staafje geeft aan dat er wegens onvoldoende waarnemingen geen informatie voor de betreffende groep kan worden gegeven. Bedrijfstype (15) Specialist COP zijn gespecialiseerde bedrijven met granen, oliezaden en eiwitgewassen. Bron: FADN; bewerking Wageningen Economic Research.

Share of P1 payments in family farm income per FWU in Bulgaria (2015)

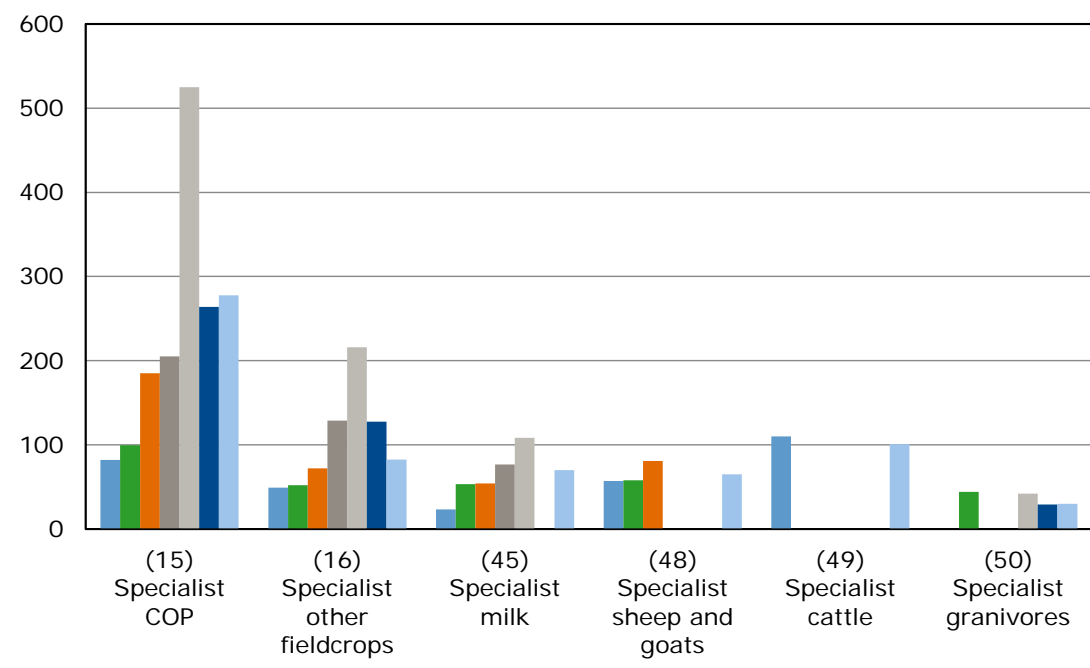

- (1) $2000-<8000$ EUR

- (2) $8000-<25000$ EUR

(3) $25000-<50000$ EUR

-(4) $50000-<100000 \mathrm{EUR}$

$\square(5) 100000-<500000$ EUR

- (6) $>=500000$ EUR

$\square$ total

Figuur B2.2 Aandeel van de inkomenstoeslagen van de eerste pijler van het GLB in het gezinsinkomen uit bedrijf per gezinsarbeidskracht op de verschillende bedrijfstypen in Bulgarije, 2015 Bron en toelichting: zie figuur B2.1. 
Share of P1 payments in family farm income per FWU in Czech Republic (2015)

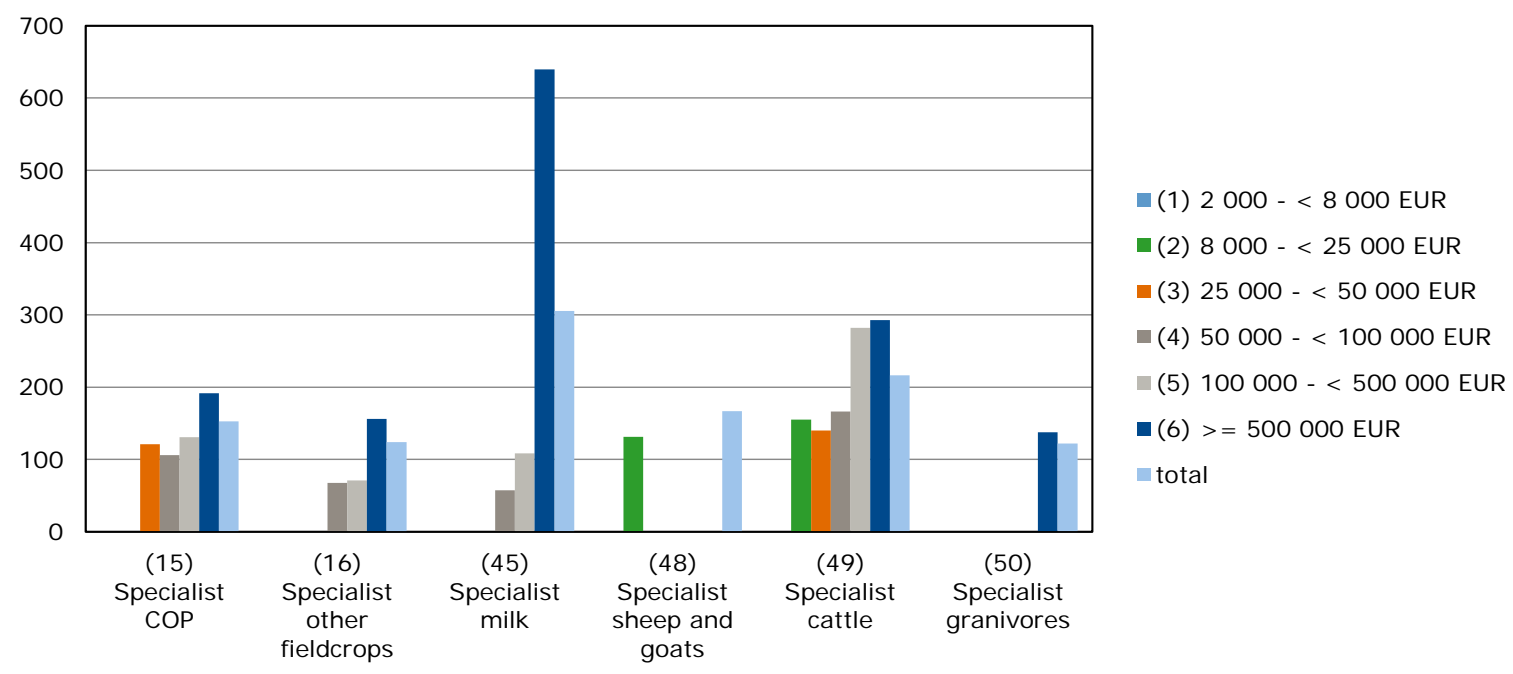

Figuur B2.3 Aandeel van de inkomenstoeslagen van de eerste pijler van het GLB in het gezinsinkomen uit bedrijf per gezinsarbeidskracht op de verschillende bedrijfstypen in Tsjechië, 2015 Bron en toelichting: zie figuur B2.1.

Share of P1 payments in family farm income per FWU in Denmark (2015)

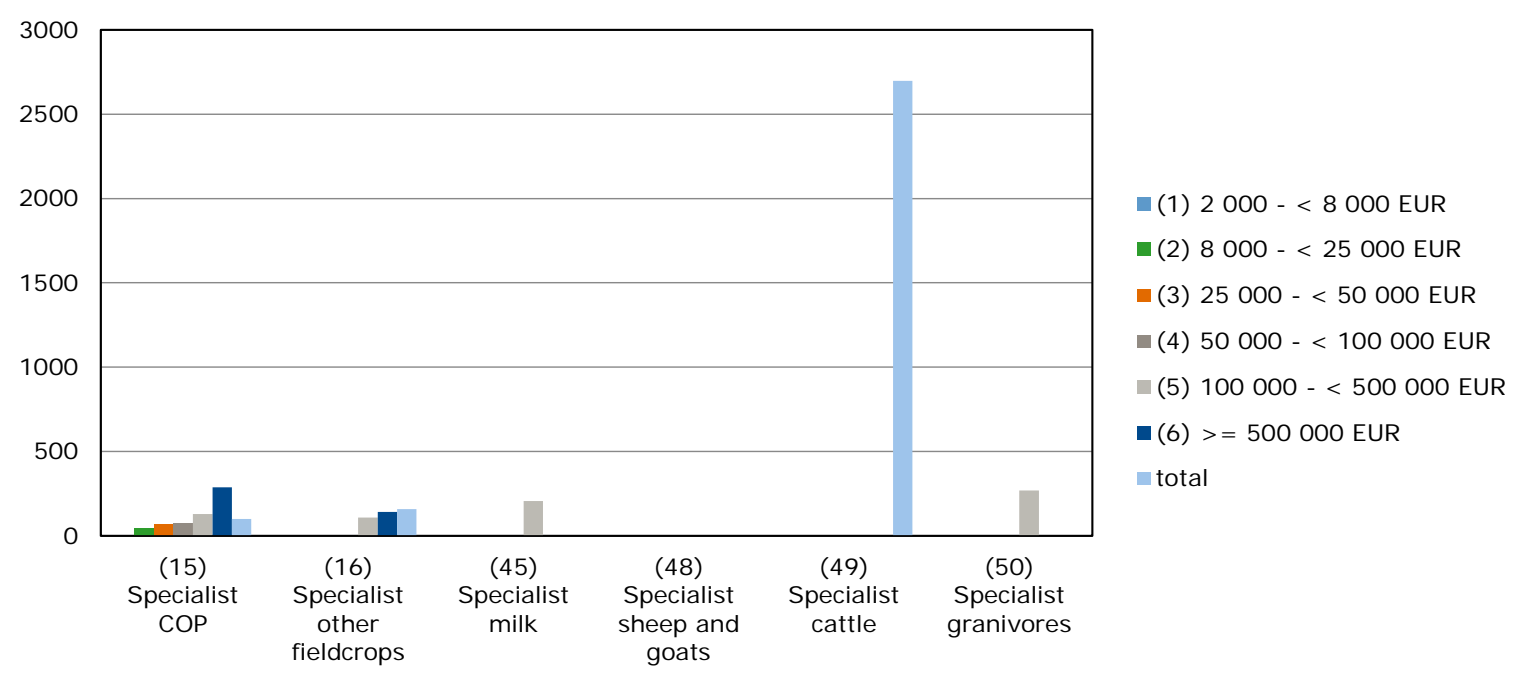

Figuur B2.4 Aandeel van de inkomenstoeslagen van de eerste pijler van het GLB in het gezinsinkomen uit bedrijf per gezinsarbeidskracht op de verschillende bedrijfstypen in Denemarken 2015

Bron en toelichting: zie figuur B2.1. 


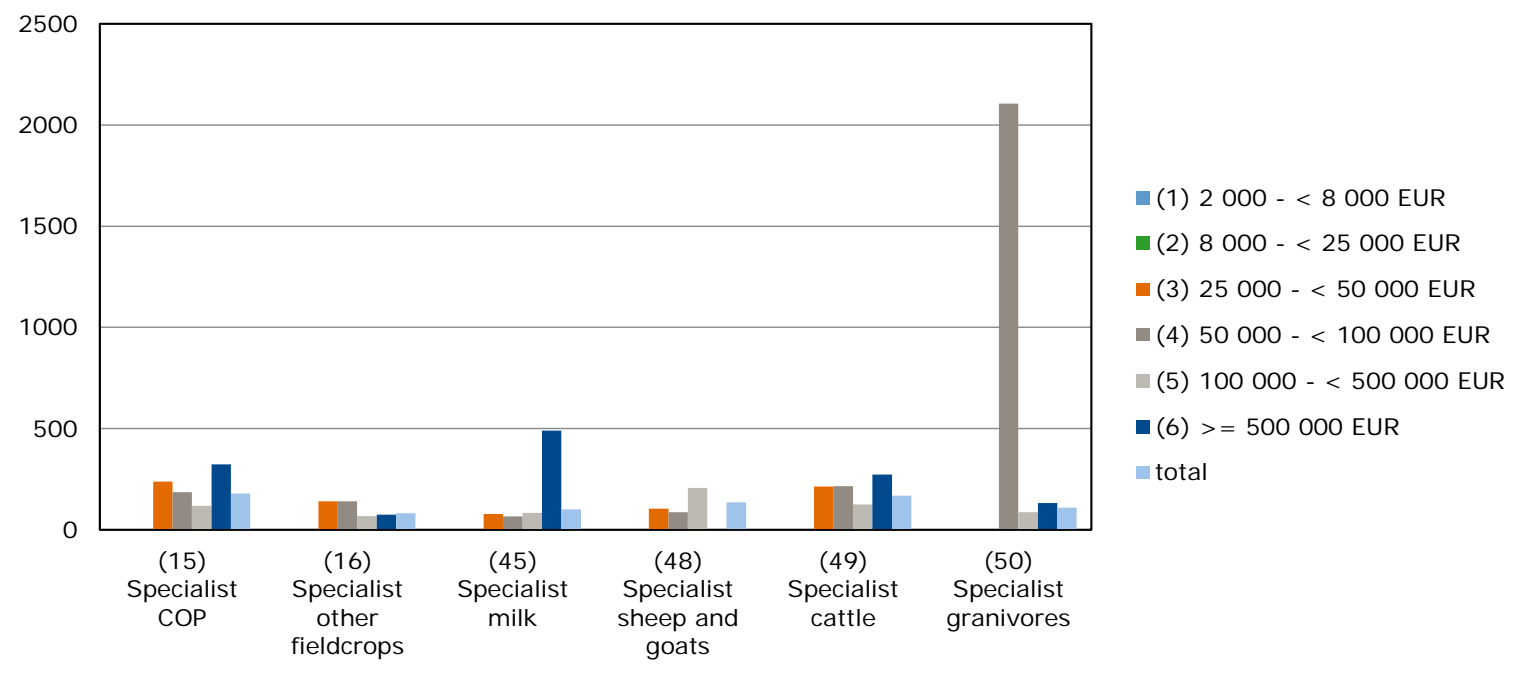

Figuur B2.5 Aandeel van de inkomenstoeslagen van de eerste pijler van het GLB in het gezinsinkomen uit bedrijf per gezinsarbeidskracht op de verschillende bedrijfstypen in Duitsland, 2015 Bron en toelichting: zie figuur B2.1.

Share of P1 payments in family farm income per FWU in Estonia (2015)

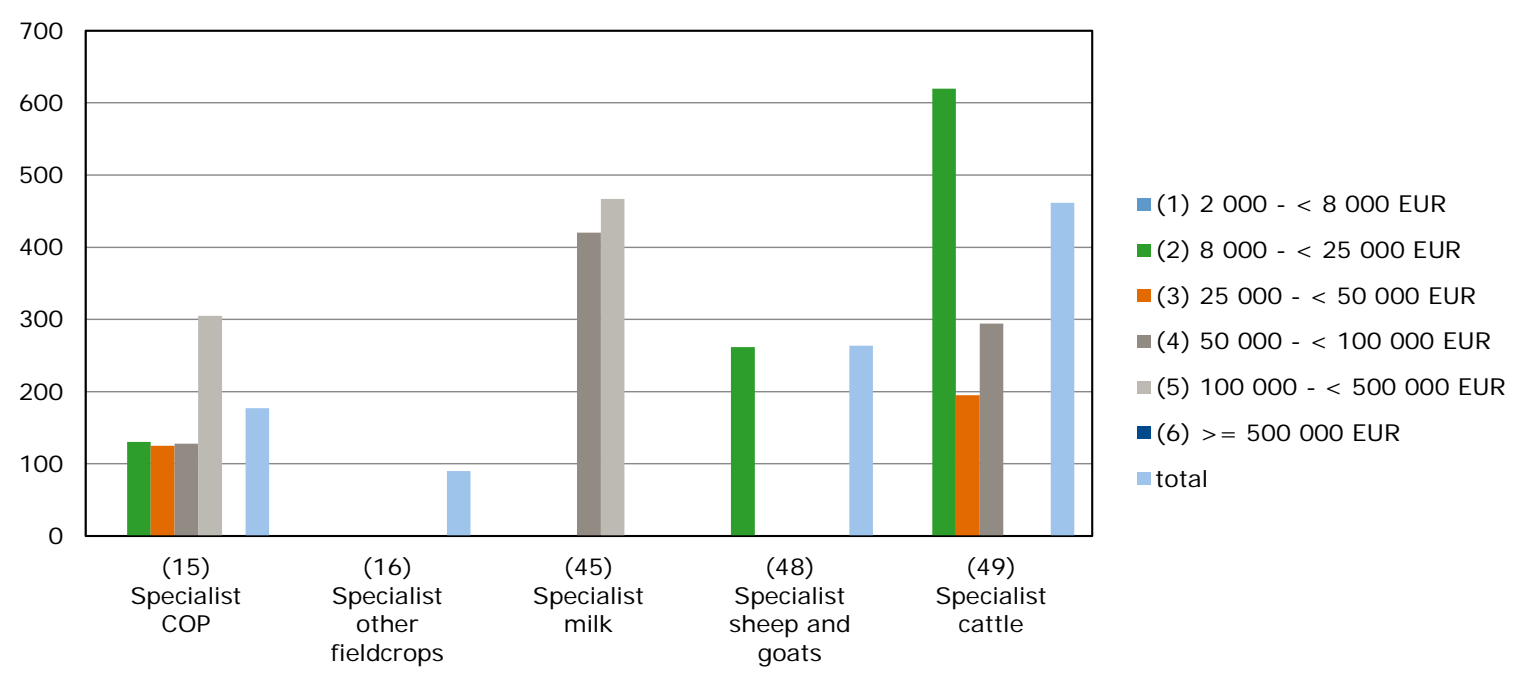

Figuur B2.6 Aandeel van de inkomenstoeslagen van de eerste pijler van het GLB in het gezinsinkomen uit bedrijf per gezinsarbeidskracht op de verschillende bedrijfstypen in Estland, 2015 Bron en toelichting: zie figuur B2.1. 


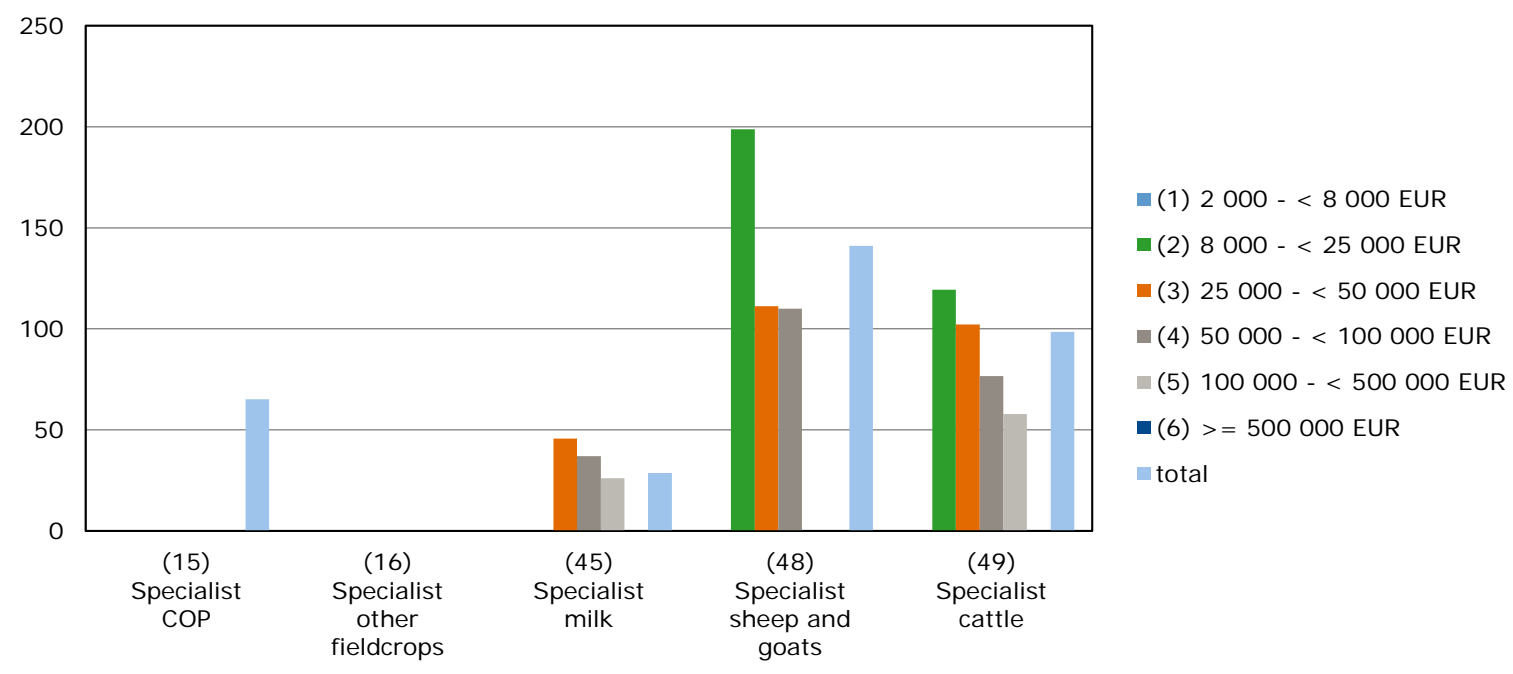

Figuur B2.7 Aandeel van de inkomenstoeslagen van de eerste pijler van het GLB in het gezinsinkomen uit bedrijf per gezinsarbeidskracht op de verschillende bedrijfstypen in Ierland, 2015 Bron en toelichting: zie figuur B2.1.

Share of P1 payments in family farm income per FWU in Greece (2015)

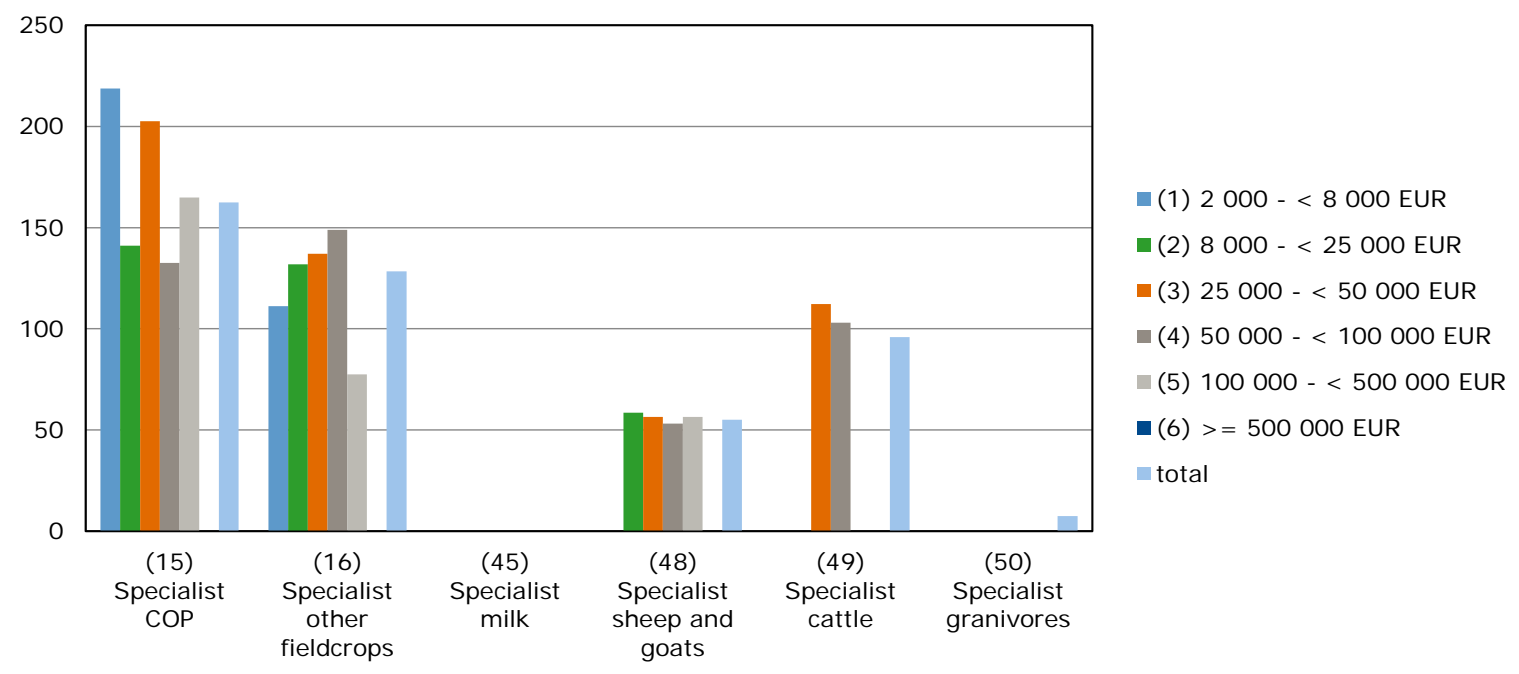

Figuur B2.8 Aandeel van de inkomenstoeslagen van de eerste pijler van het GLB in het gezinsinkomen uit bedrijf per gezinsarbeidskracht op de verschillende bedrijfstypen in Griekenland, 2015

Bron en toelichting: zie figuur B2.1. 


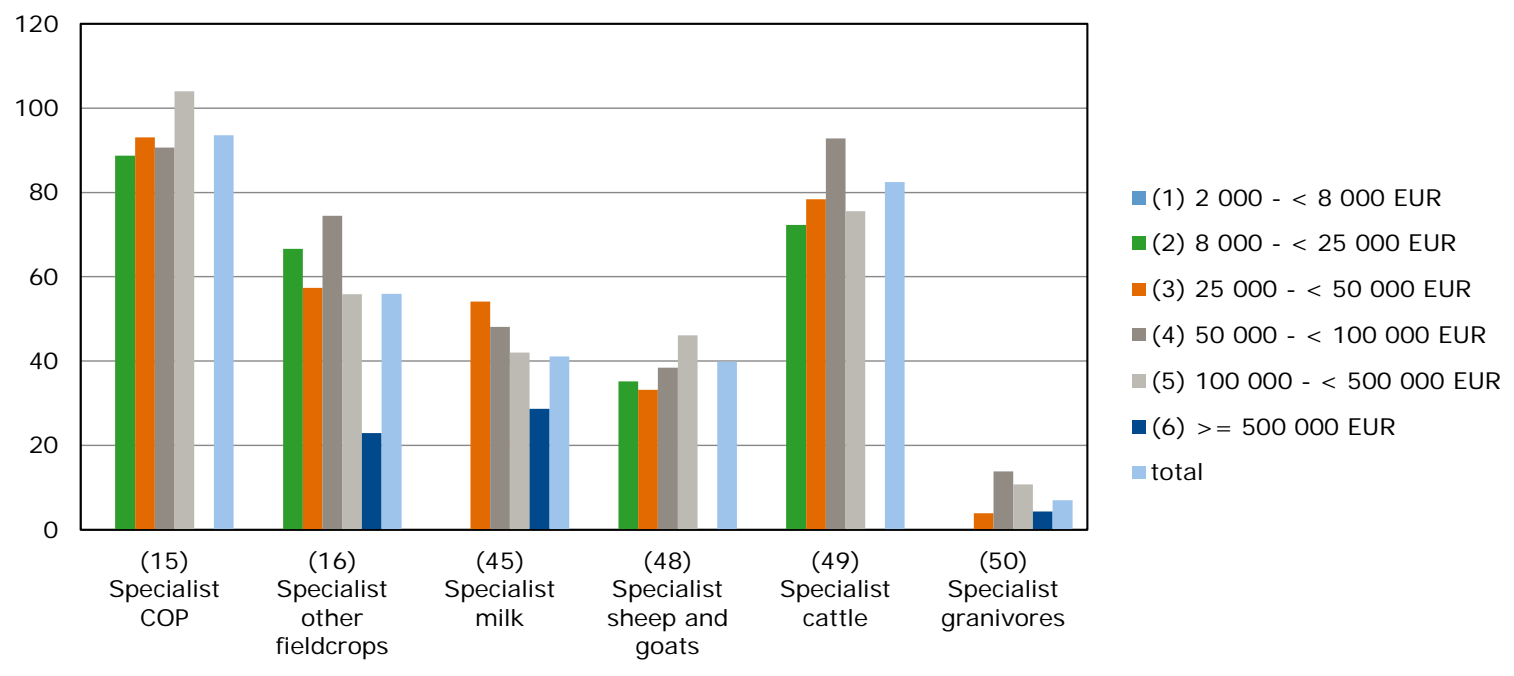

Figuur B2.9 Aandeel van de inkomenstoeslagen van de eerste pijler van het GLB in het gezinsinkomen uit bedrijf per gezinsarbeidskracht op de verschillende bedrijfstypen in Spanje, 2015 Bron en toelichting: zie figuur B2.1.

Share of P1 payments in family farm income per FWU in France (2015)

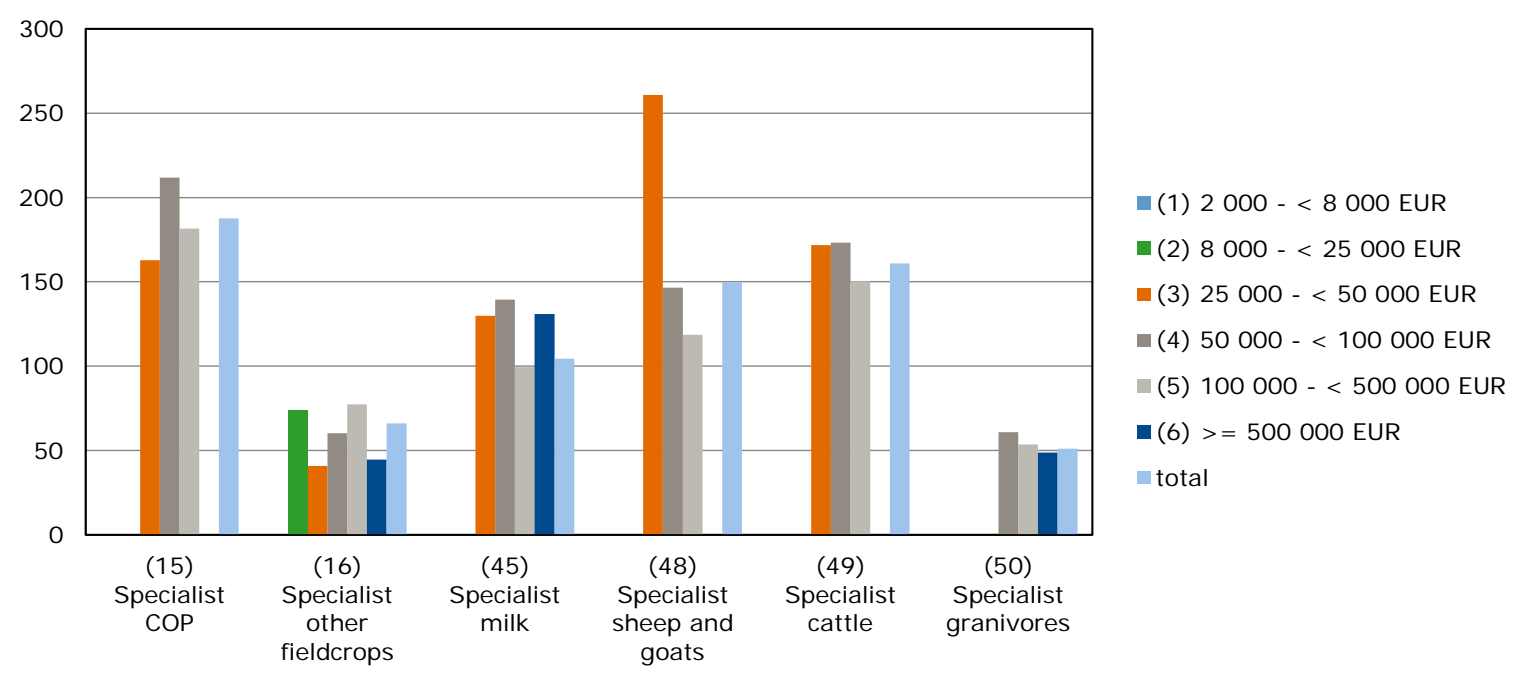

Figuur B2.10 Aandeel van de inkomenstoeslagen van de eerste pijler van het GLB in het gezinsinkomen uit bedrijf per gezinsarbeidskracht op de verschillende bedrijfstypen in Frankrijk, 2015 Bron en toelichting: zie figuur B2.1. 


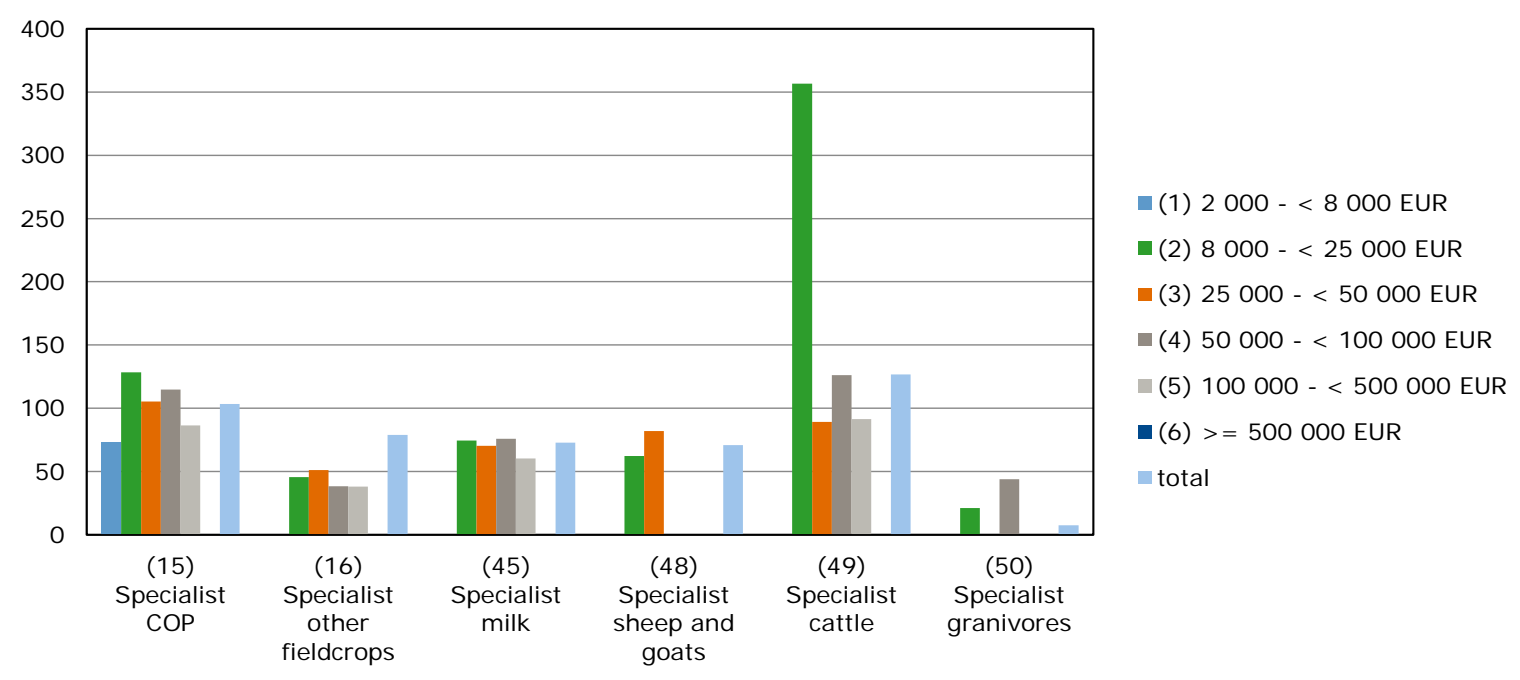

Figuur B2.11 Aandeel van de inkomenstoeslagen van de eerste pijler van het GLB in het gezinsinkomen uit bedrijf per gezinsarbeidskracht op de verschillende bedrijfstypen in Kroatië, 2015 Bron en toelichting: zie figuur B2.1.

Share of P1 payments in family farm income per FWU in Italy (2015)

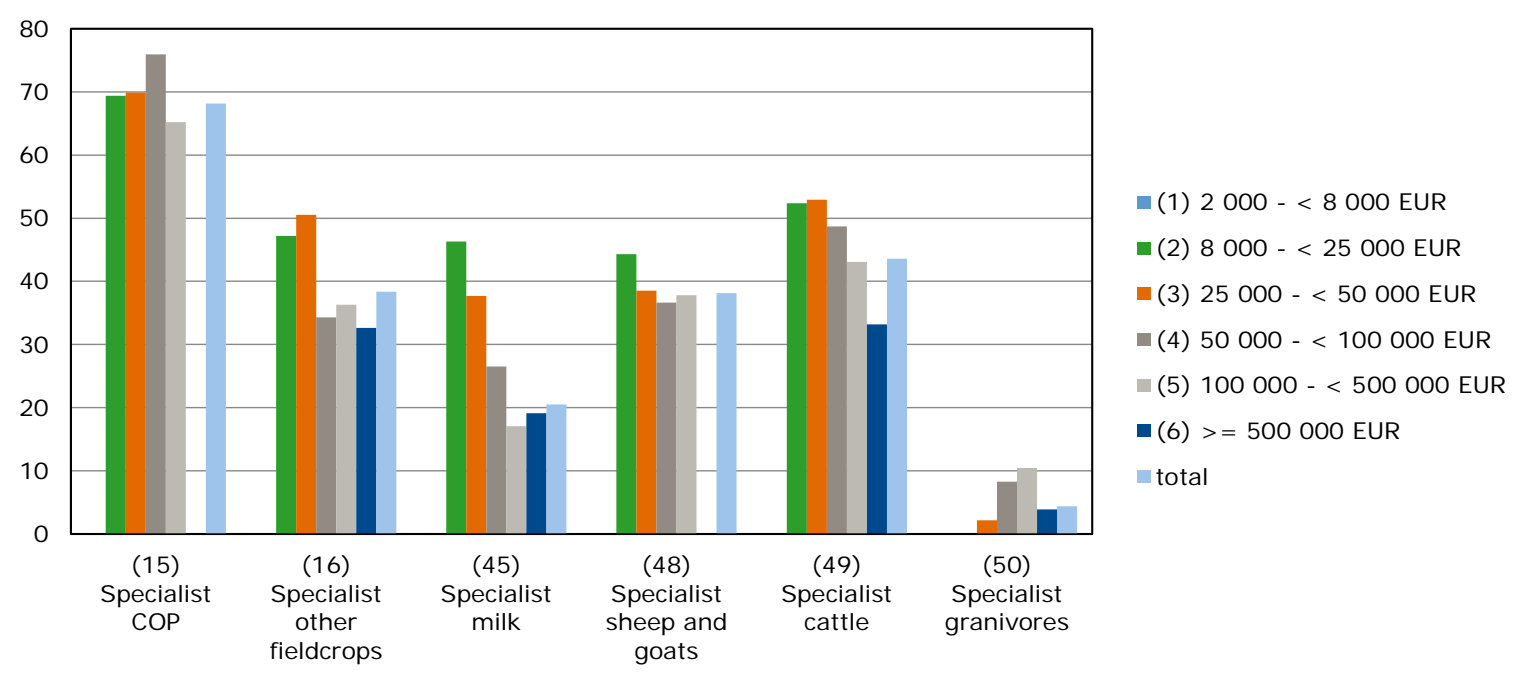

Figuur B2.12 Aandeel van de inkomenstoeslagen van de eerste pijler van het GLB in het gezinsinkomen uit bedrijf per gezinsarbeidskracht op de verschillende bedrijfstypen in Italië, 2015 Bron en toelichting: zie figuur B2.1. 


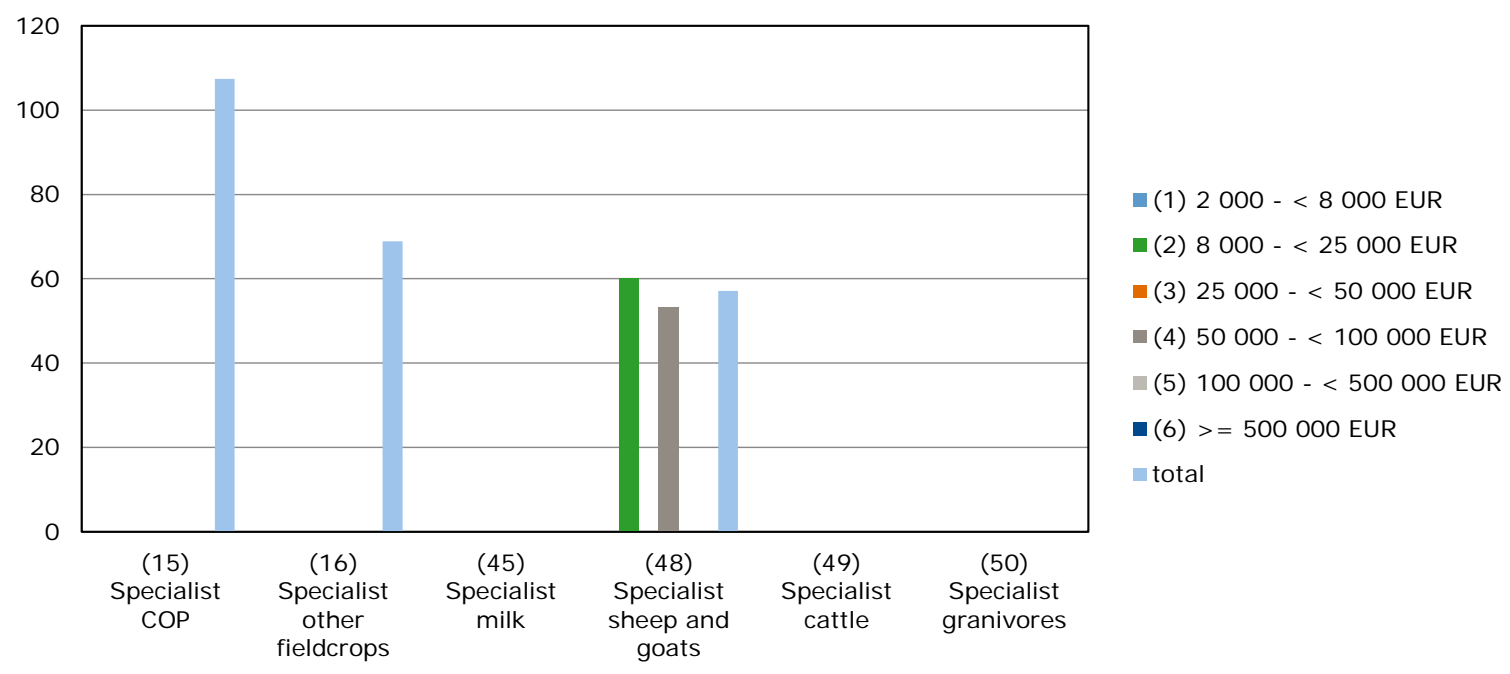

Figuur B2.13 Aandeel van de inkomenstoeslagen van de eerste pijler van het GLB in het gezinsinkomen uit bedrijf per gezinsarbeidskracht op de verschillende bedrijfstypen op Cyprus, 2015 Bron en toelichting: zie figuur B2.1.

Share of P1 payments in family farm income per FWU in Latvia (2015)

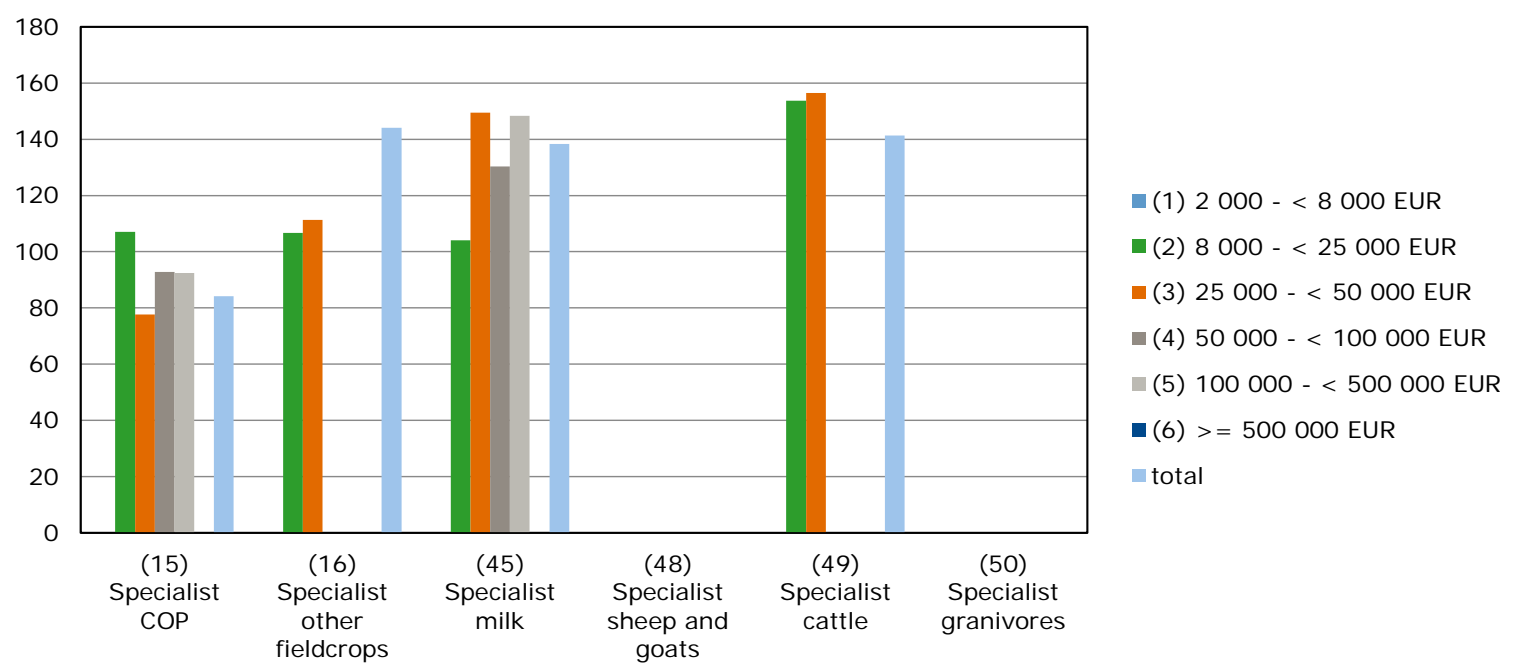

Figuur B2.14 Aandeel van de inkomenstoeslagen van de eerste pijler van het GLB in het gezinsinkomen uit bedrijf per gezinsarbeidskracht op de verschillende bedrijfstypen in Letland, 2015 Bron en toelichting: zie figuur B2.1. 
Share of P1 payments in family farm income per FWU in Lithuania (2015)

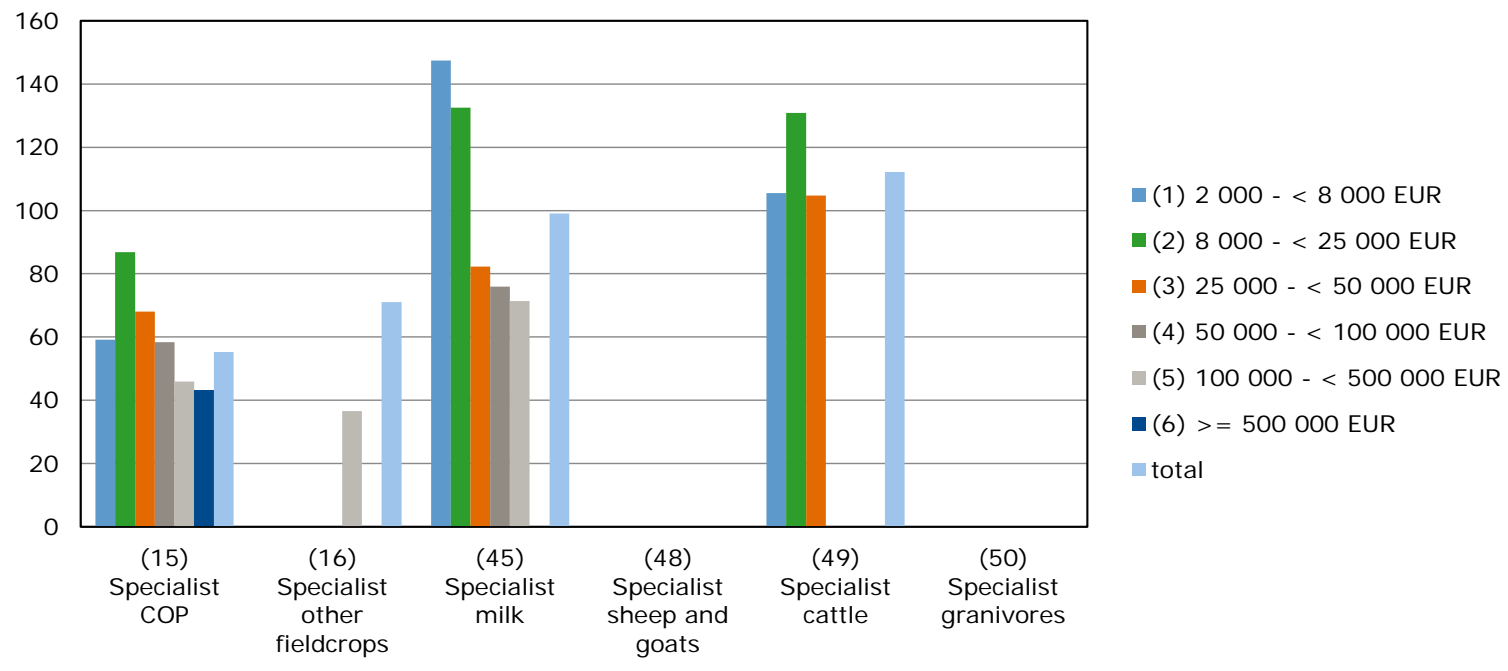

Figuur B2.15 Aandeel van de inkomenstoeslagen van de eerste pijler van het GLB in het gezinsinkomen uit bedrijf per gezinsarbeidskracht op de verschillende bedrijfstypen in Litouwen, 2015 Bron en toelichting: zie figuur B2.1.

Share of P1 payments in family farm income per FWU in Luxembourg (2015)

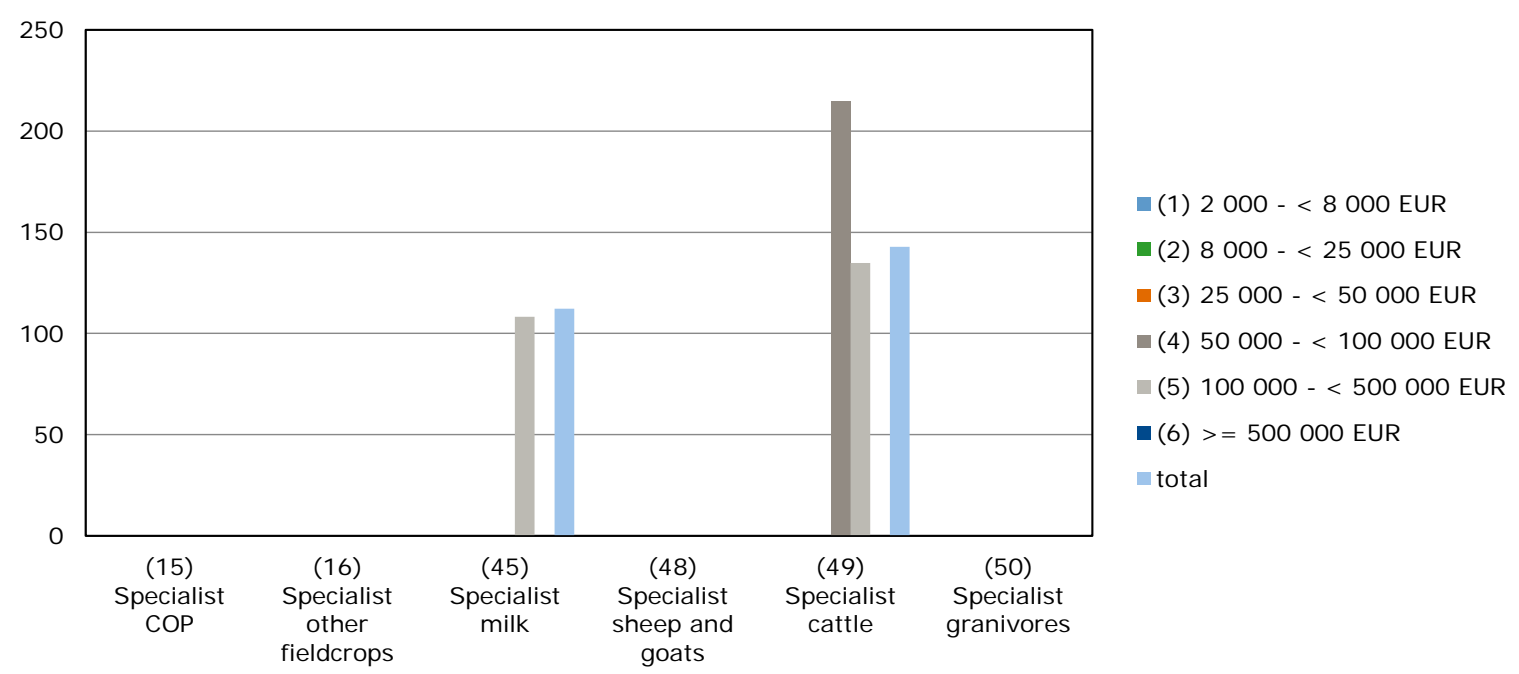

Figuur B2.16 Aandeel van de inkomenstoeslagen van de eerste pijler van het GLB in het gezinsinkomen uit bedrijf per gezinsarbeidskracht op de verschillende bedrijfstypen in Luxemburg, 2015

Bron en toelichting: zie figuur B2.1. 
Share of P1 payments in family farm income per FWU in Hungary (2015)

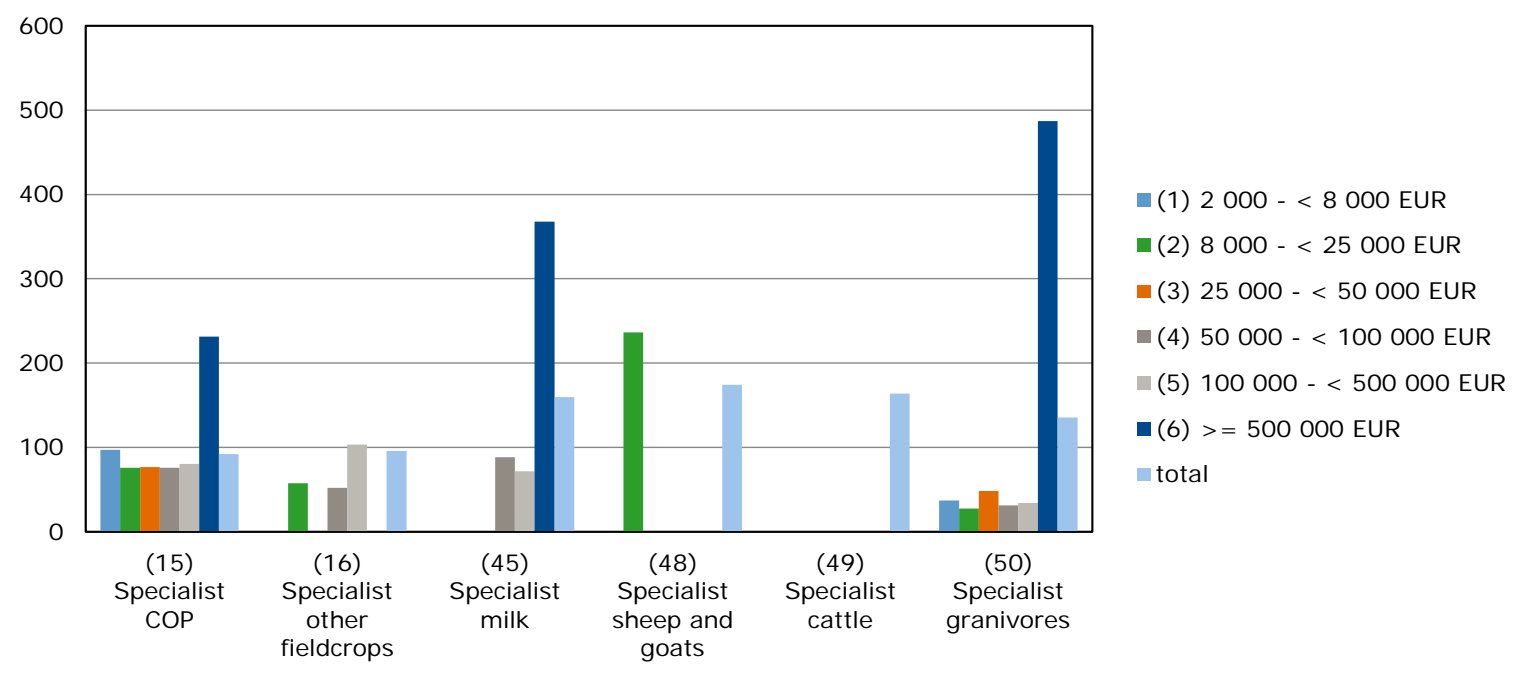

Figuur B2.17 Aandeel van de inkomenstoeslagen van de eerste pijler van het GLB in het gezinsinkomen uit bedrijf per gezinsarbeidskracht op de verschillende bedrijfstypen in Hongarije, 2015 Bron en toelichting: zie figuur B2.1.

Share of P1 payments in family farm income per FWU in Malta (2015)

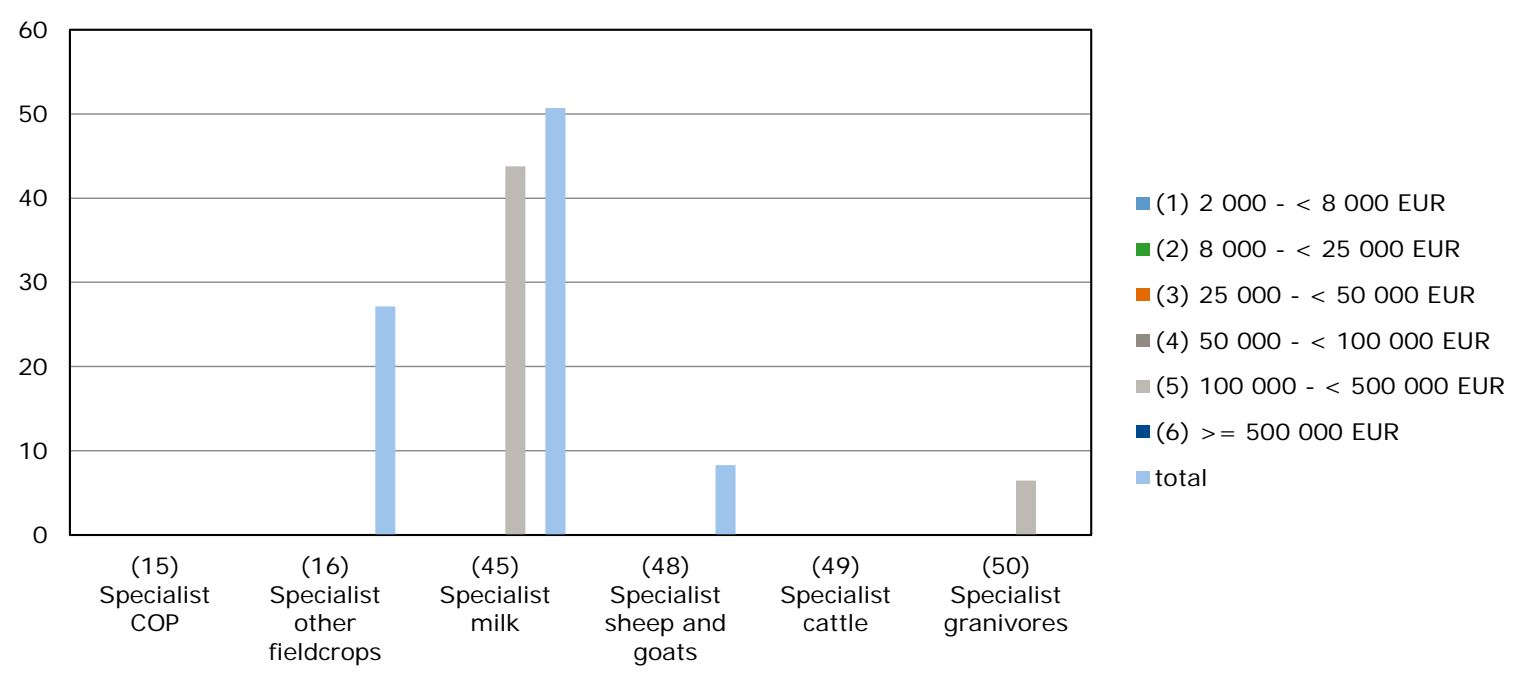

Figuur B2.18 Aandeel van de inkomenstoeslagen van de eerste pijler van het GLB in het gezinsinkomen uit bedrijf per gezinsarbeidskracht op de verschillende bedrijfstypen op Malta, 2015 Bron en toelichting: zie figuur B2.1. 
Share of P1 payments in family farm income per FWU in Netherlands (2015)

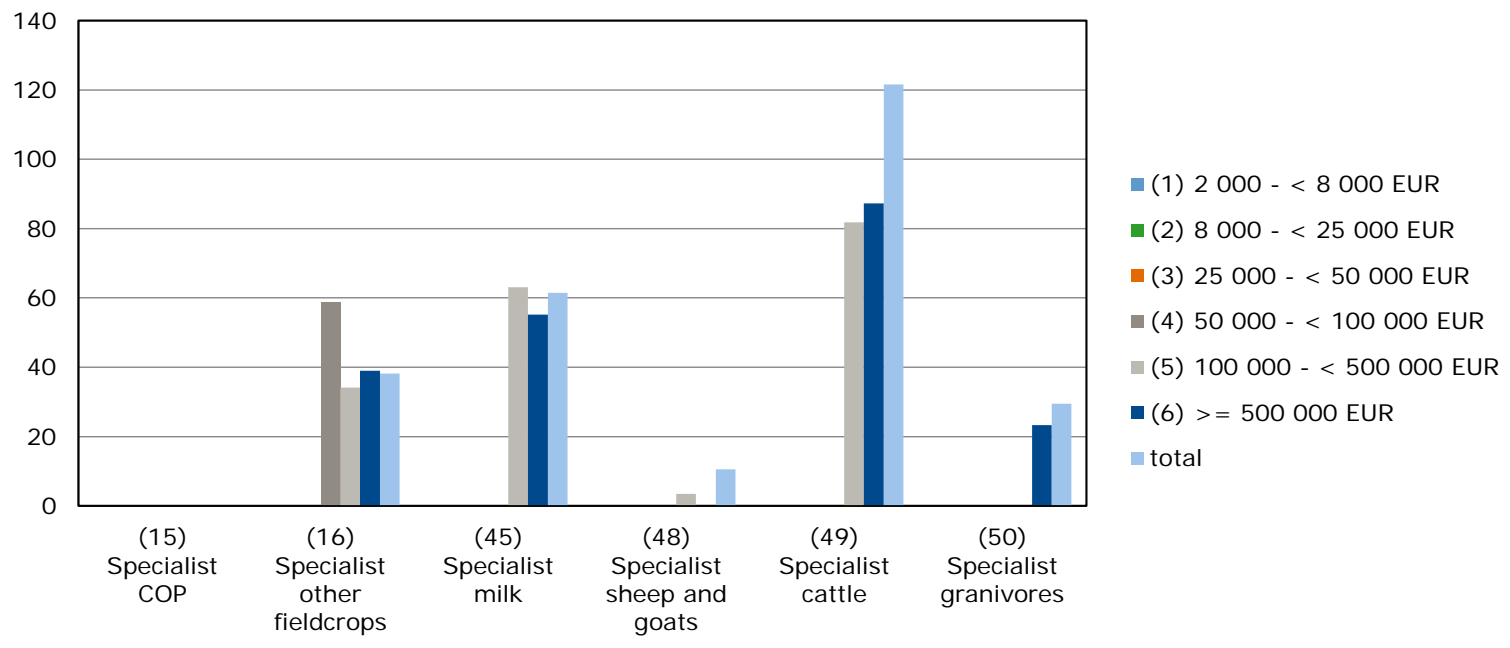

Figuur B2.19 Aandeel van de inkomenstoeslagen van de eerste pijler van het GLB in het gezinsinkomen uit bedrijf per gezinsarbeidskracht op de verschillende bedrijfstypen in Nederland, 2015

Bron en toelichting: zie figuur B2.1.

Share of P1 payments in family farm income per FWU in Austria (2015)

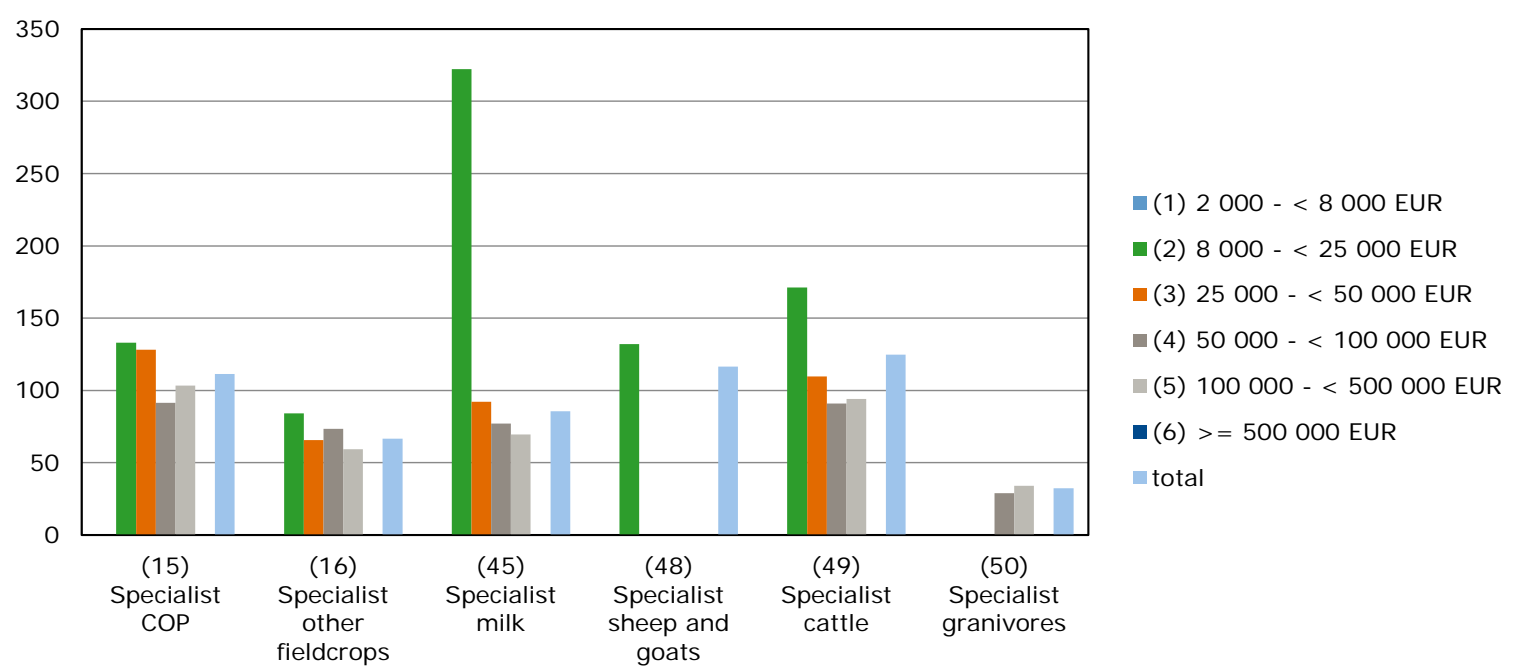

Figuur B2.20 Aandeel van de inkomenstoeslagen van de eerste pijler van het GLB in het gezinsinkomen uit bedrijf per gezinsarbeidskracht op de verschillende bedrijfstypen in Oostenrijk, 2015

Bron en toelichting: zie figuur B2.1. 
Share of P1 payments in family farm income per FWU in Poland (2015)

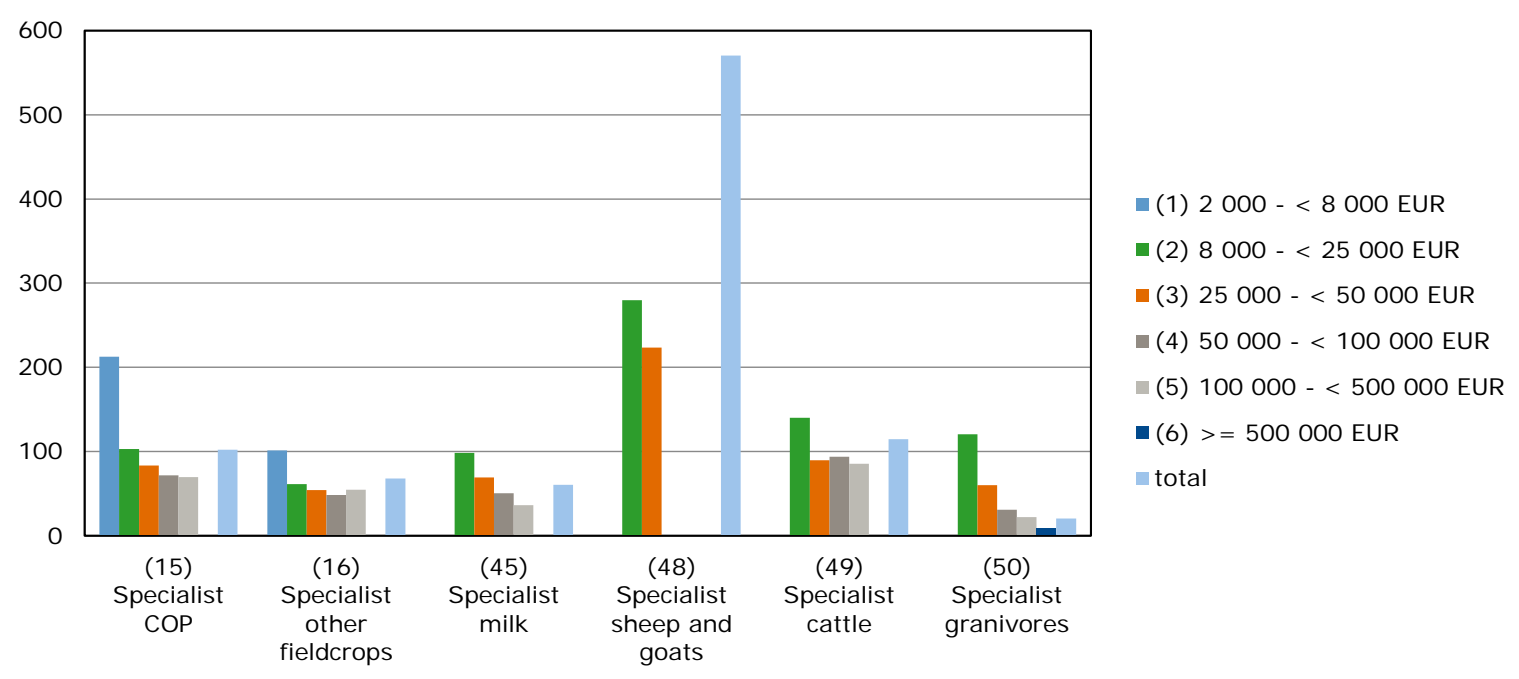

Figuur B2.21 Aandeel van de inkomenstoeslagen van de eerste pijler van het GLB in het gezinsinkomen uit bedrijf per gezinsarbeidskracht op de verschillende bedrijfstypen in Polen, 2015 Bron en toelichting: zie figuur B2.1.

Share of P1 payments in family farm income per FWU in Portugal (2015)

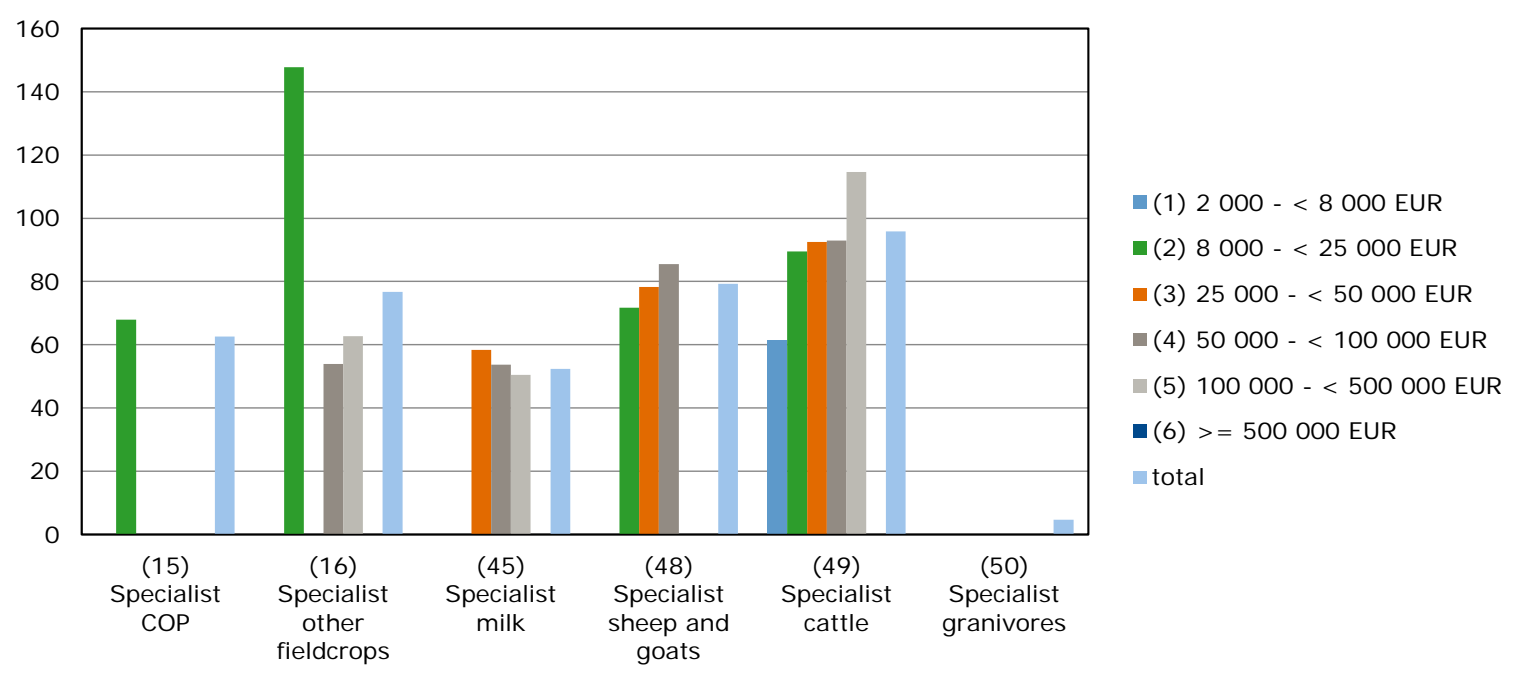

Figuur B2.22 Aandeel van de inkomenstoeslagen van de eerste pijler van het GLB in het gezinsinkomen uit bedrijf per gezinsarbeidskracht op de verschillende bedrijfstypen in Portugal, 2015 Bron en toelichting: zie figuur B2.1. 
Share of P1 payments in family farm income per FWU in Romania (2015)

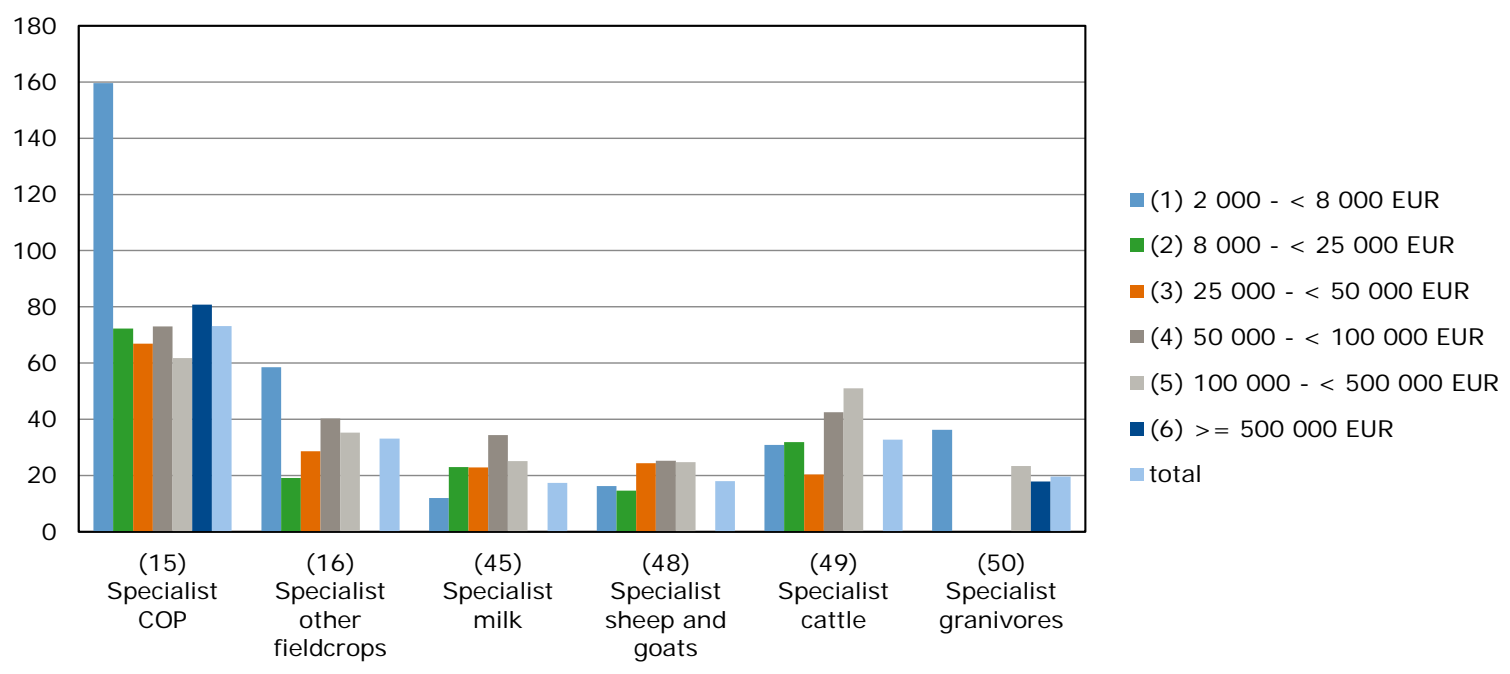

Figuur B2.23 Aandeel van de inkomenstoeslagen van de eerste pijler van het GLB in het gezinsinkomen uit bedrijf per gezinsarbeidskracht op de verschillende bedrijfstypen in Roemenië, 2015 Bron en toelichting: zie figuur B2.1.

Share of P1 payments in family farm income per FWU in Slovenia (2015)

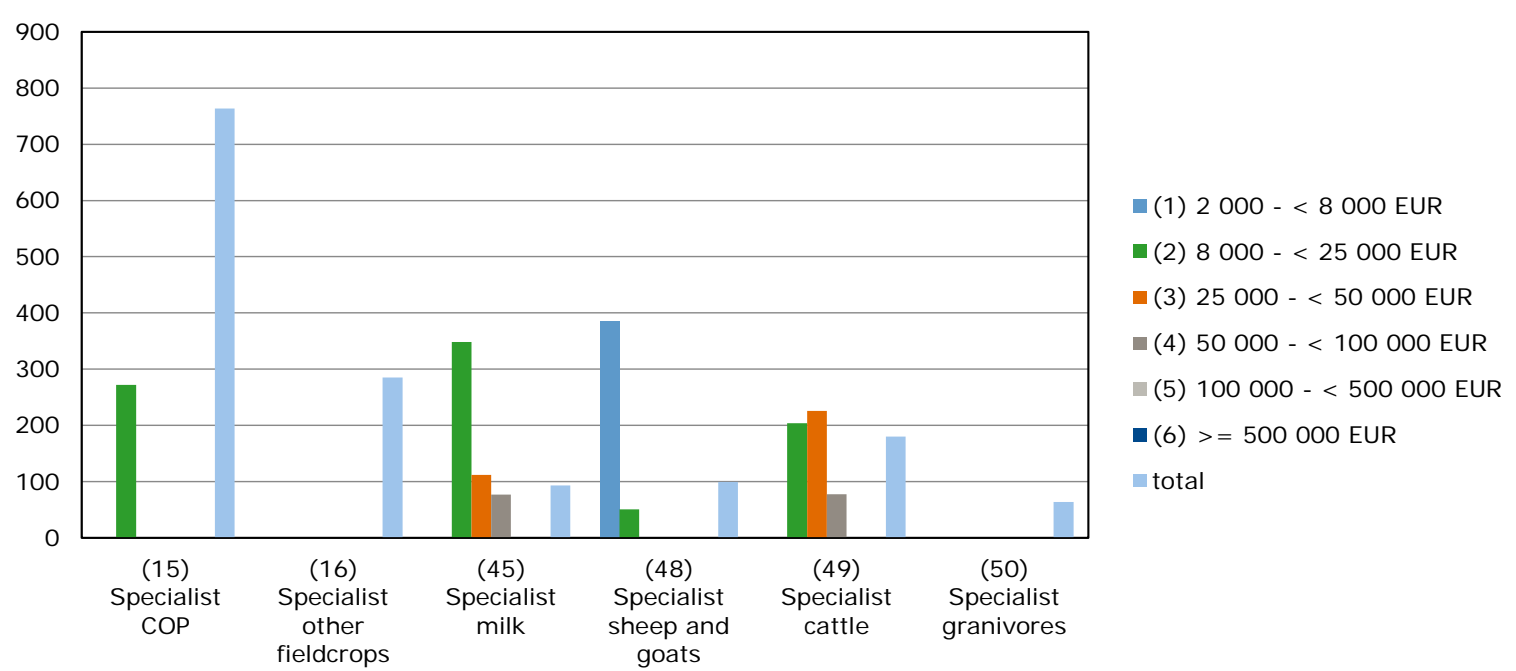

Figuur B2.24 Aandeel van de inkomenstoeslagen van de eerste pijler van het GLB in het gezinsinkomen uit bedrijf per gezinsarbeidskracht op de verschillende bedrijfstypen in Slovenië, 2015 Bron en toelichting: zie figuur B2.1. 
Share of P1 payments in family farm income per FWU in Slovakia (2015)

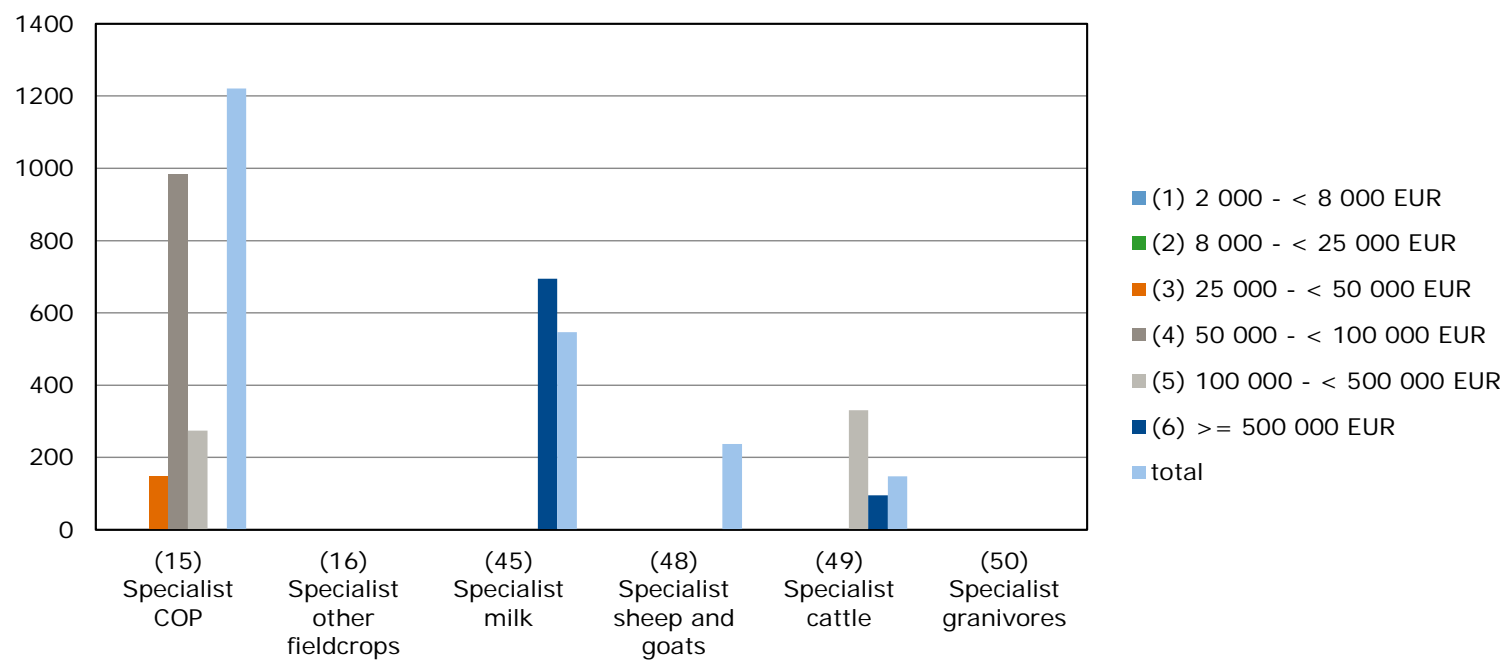

Figuur B2.25 Aandeel van de inkomenstoeslagen van de eerste pijler van het GLB in het gezinsinkomen uit bedrijf per gezinsarbeidskracht op de verschillende bedrijfstypen in Slowakije, 2015 Bron en toelichting: zie figuur B2.1.

Share of P1 payments in family farm income per FWU in Finland (2015)

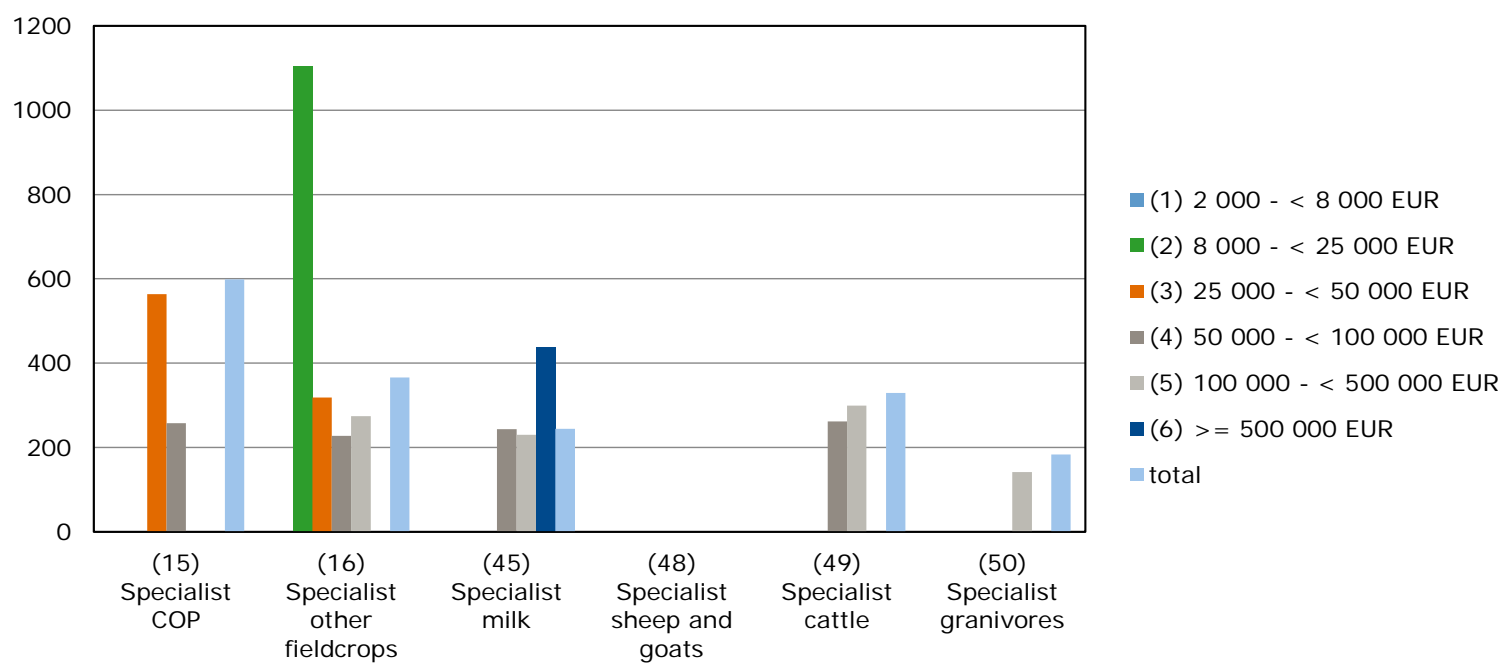

Figuur B2.26 Aandeel van de inkomenstoeslagen van de eerste pijler van het GLB in het gezinsinkomen uit bedrijf per gezinsarbeidskracht op de verschillende bedrijfstypen in Finland, 2015 Bron en toelichting: zie figuur B2.1. 
Share of P1 payments in family farm income per FWU in Sweden (2015)

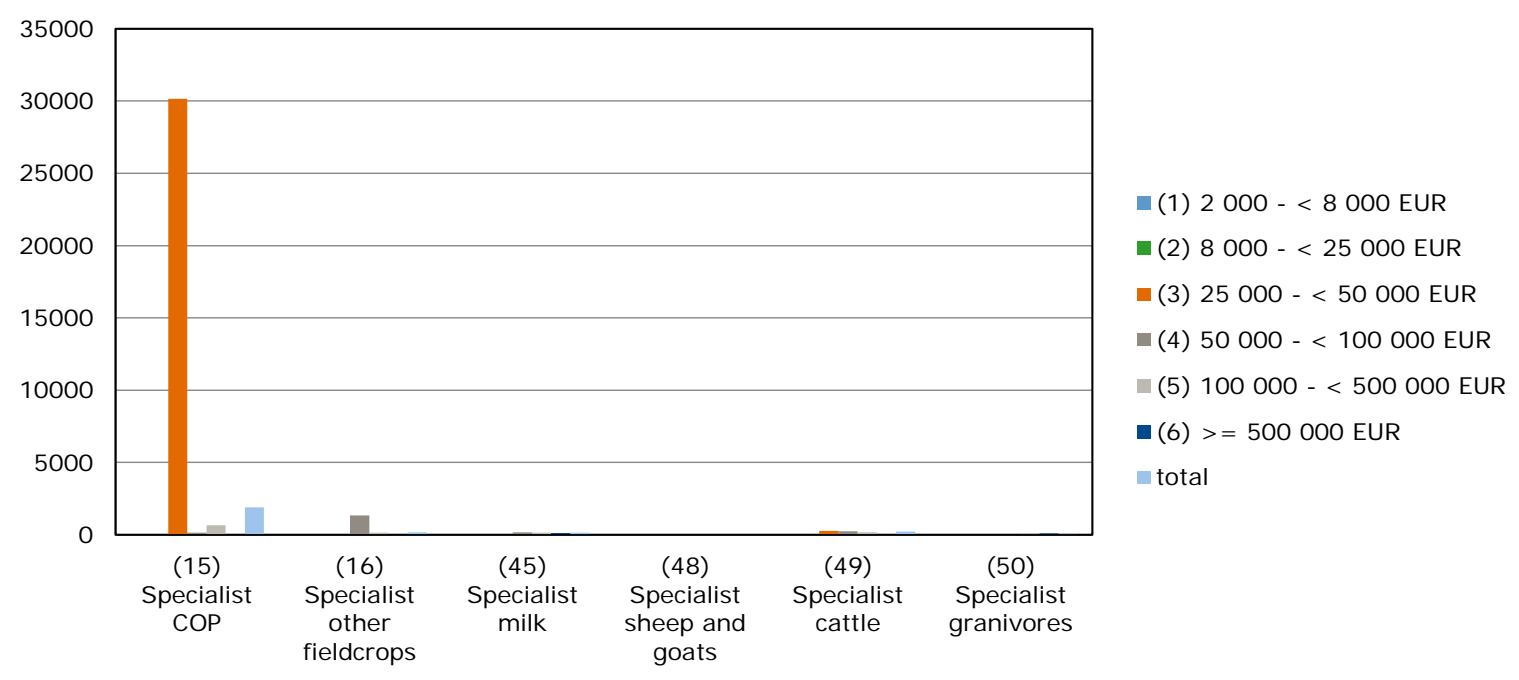

Figuur B2.27 Aandeel van de inkomenstoeslagen van de eerste pijler van het GLB in het gezinsinkomen uit bedrijf per gezinsarbeidskracht op de verschillende bedrijfstypen in Zweden, 2015 Bron en toelichting: zie figuur B2.1.

Share of P1 payments in family farm income per FWU in United Kingdom (2015)

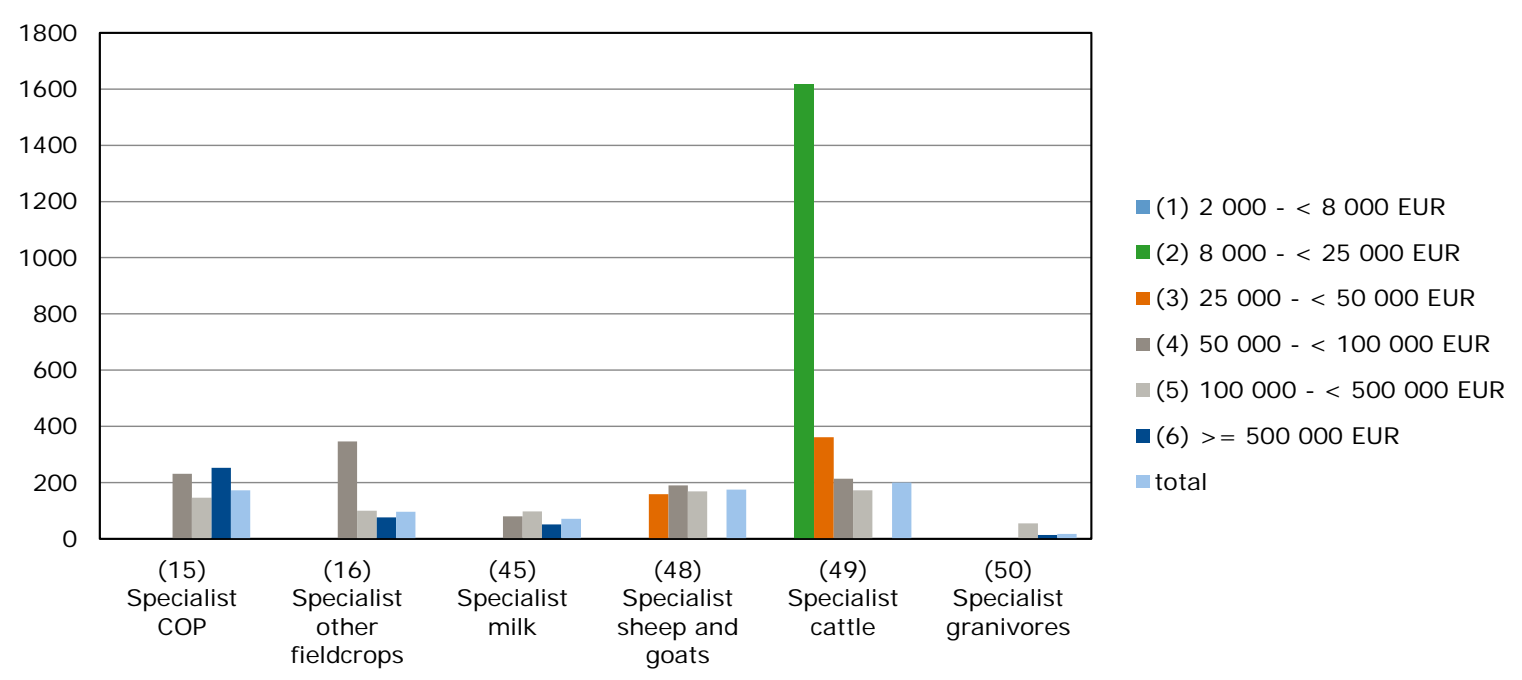

Figuur B2.28 Aandeel van de inkomenstoeslagen van de eerste pijler van het GLB in het gezinsinkomen uit bedrijf per gezinsarbeidskracht op de verschillende bedrijfstypen in het VK, 2015 Bron en toelichting: zie figuur B2.1. 


\section{Bijlage 3 Tabellen}

Tabel B3.1 Aandeel boeren dat 20\% van de toeslagen ontvangt in de EU-lidstaten, 2015 ( $\%$ van totaal aantal boeren)

\begin{tabular}{|c|c|c|c|c|}
\hline & $\begin{array}{l}\text { Aandeel op basis van } \\
\text { de (werkelifke) } \\
\text { verdeling in } 2015\end{array}$ & $\begin{array}{l}\text { Berekende uniforme } \\
\text { hectarepremie in } \\
2015 \text { (€) }\end{array}$ & $\begin{array}{l}\text { Aandeel op basis van de } \\
\text { fictieve verdeling } \\
\text { ( berekend met een } \\
\text { uniforme hectarepremie) }\end{array}$ & $\begin{array}{l}\text { Verschil verdeling } \\
\text { in } 2015 \text { en fictieve } \\
\text { verdeling }\end{array}$ \\
\hline & (1) & (2) & (3) & $(1)-(3)$ \\
\hline Luxembourg & 54 & 256 & 56 & -2 \\
\hline Ireland & 55 & 245 & 52 & 3 \\
\hline Netherlands & 56 & 416 & 63 & -6 \\
\hline Belgium & 58 & 404 & 57 & 0,3 \\
\hline France & 59 & 271 & 65 & -5 \\
\hline Finland & 60 & 229 & 53 & 6 \\
\hline Austria & 61 & 254 & 61 & 0,0 \\
\hline United Kingdom & 64 & 206 & 71 & -6 \\
\hline Slovenia & 65 & 282 & 58 & 7 \\
\hline Greece & 66 & 454 & 79 & -13 \\
\hline Poland & 68 & 209 & 64 & 3 \\
\hline Germany & 68 & 306 & 67 & 0,3 \\
\hline Sweden & 74 & 230 & 69 & 5 \\
\hline Denmark & 75 & 346 & 69 & 6 \\
\hline Croatia & 75 & 95 & 79 & -4 \\
\hline Malta & 76 & 460 & 38 & 37 \\
\hline Lithuania & 76 & 155 & 77 & -1 \\
\hline Cyprus & 76 & 459 & 78 & -2 \\
\hline Italy & 78 & 318 & 72 & 5 \\
\hline Spain & 78 & 211 & 82 & -4 \\
\hline Latvia & 81 & 118 & 79 & 2 \\
\hline Hungary & 84 & 273 & 91 & -7 \\
\hline Bulgaria & 84 & 171 & 92 & -8 \\
\hline Portugal & 85 & 158 & 88 & -3 \\
\hline Estonia & 86 & 140 & 85 & 1 \\
\hline Romania & 87 & 139 & 82 & 5 \\
\hline Czech Republic & 89 & 250 & 82 & 7 \\
\hline Slovakia & 93 & 202 & 91 & 2 \\
\hline EU28 & 81 & 243 & 86 & -6 \\
\hline
\end{tabular}

Bron: EC (2017b) en Eurostat Farm Structure Survey (FSS); bewerking Wageningen Economic Research. 
Tabel B3.2 Aantal boeren met weinig en veel ontvangsten aan toeslagen in de EU-lidstaten, 2015

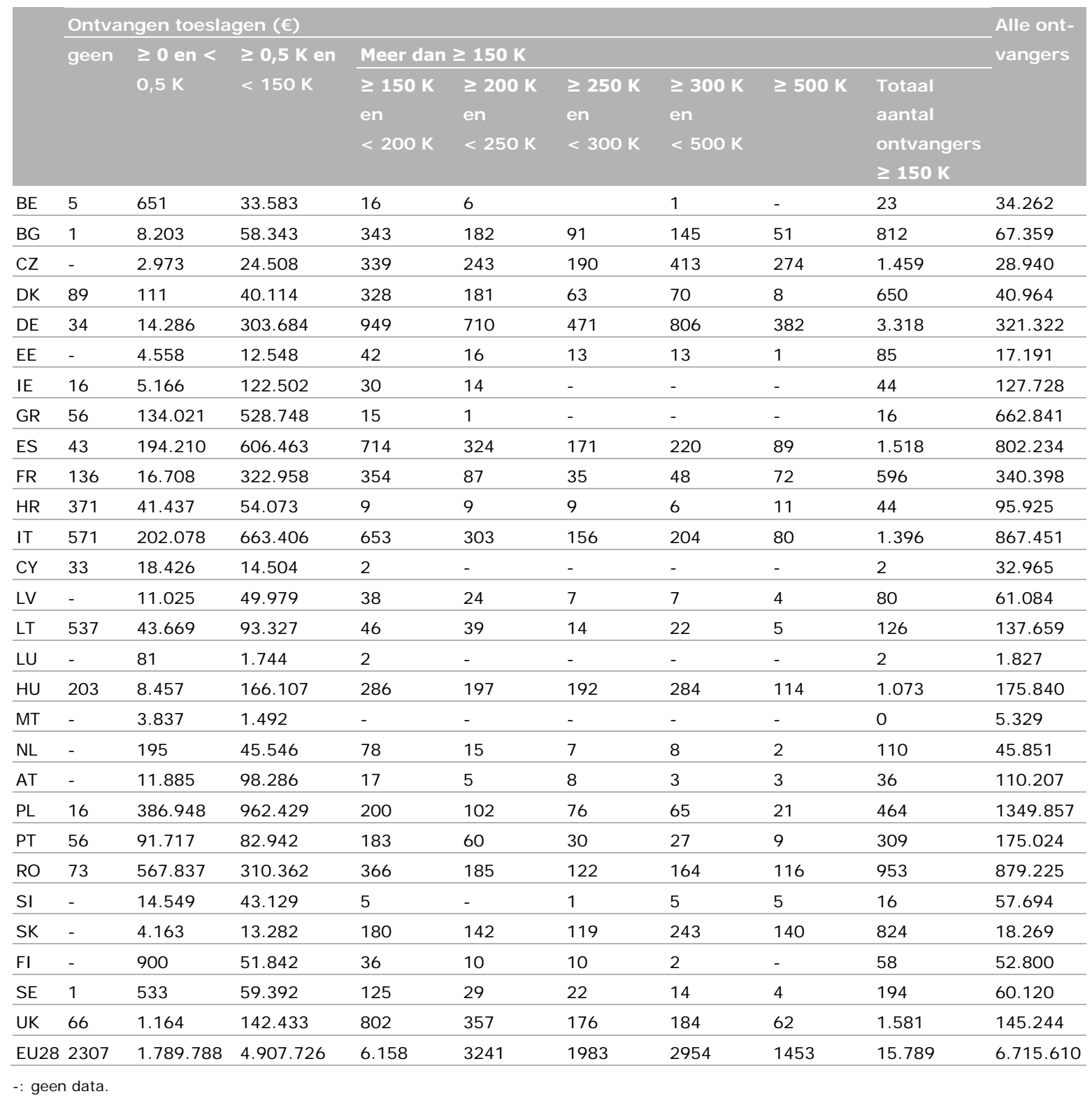

Bron: EC (2017b). 
Tabel B3.3 Aandeel boeren per ontvangstcategorie in totaal aantal boeren in de EU-lidstaten, 2015 (\% van totaal aantal boeren)

\begin{tabular}{|c|c|c|c|c|c|c|c|c|c|c|c|c|c|c|}
\hline & Ont & igen toes & slagen & & & & & & & & & & & \\
\hline & $\begin{array}{l}\text { n̊ } \\
\text { o } \\
\text { v }\end{array}$ & 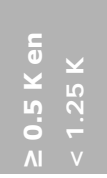 & $\begin{array}{l}\frac{5}{j} \\
\frac{1}{10} \\
N \\
\\
-1 \\
N\end{array}$ & $\begin{array}{ll}\frac{5}{0} & \\
\dddot{y} & \mathrm{Y} \\
\mathrm{N} & 10 \\
\mathrm{~N} & \mathrm{~V}\end{array}$ & 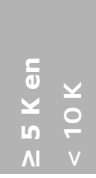 & 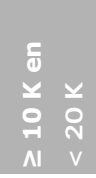 & 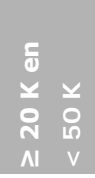 & 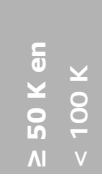 & 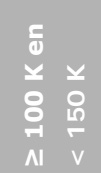 & 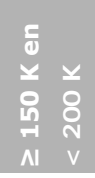 & 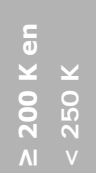 & 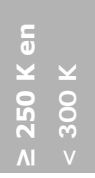 & 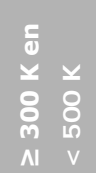 & $\begin{array}{l}1 \\
8 \\
10 \\
\text { 신 }\end{array}$ \\
\hline $\mathrm{BE}$ & 2 & 9 & 7 & 16 & 16 & 23 & 23 & 4 & 0 & 0 & 0 & 0 & 0 & 0 \\
\hline$B G$ & 12 & 26 & 12 & 20 & 13 & 8 & 5 & 2 & 1 & 1 & 0 & 0 & 0 & 0 \\
\hline$C Z$ & 10 & 17 & 11 & 21 & 12 & 10 & 8 & 3 & 2 & 1 & 1 & 1 & 1 & 1 \\
\hline DK & 0 & 15 & 11 & 21 & 13 & 12 & 14 & 9 & 2 & 1 & 0 & 0 & 0 & 0 \\
\hline $\mathrm{DE}$ & 4 & 12 & 9 & 19 & 18 & 19 & 15 & 3 & 1 & 0 & 0 & 0 & 0 & 0 \\
\hline $\mathrm{EE}$ & 27 & 28 & 12 & 14 & 7 & 5 & 5 & 2 & 1 & 0 & 0 & 0 & 0 & 0 \\
\hline IE & 4 & 7 & 7 & 26 & 25 & 19 & 10 & 1 & 0 & 0 & 0 & 0 & 0 & 0 \\
\hline GR & 20 & 28 & 13 & 21 & 10 & 5 & 2 & 0 & 0 & 0 & 0 & 0 & 0 & 0 \\
\hline ES & 24 & 22 & 11 & 18 & 10 & 8 & 6 & 1 & 0 & 0 & 0 & 0 & 0 & 0 \\
\hline FR & 5 & 9 & 5 & 11 & 11 & 19 & 32 & 8 & 1 & 0 & 0 & 0 & 0 & 0 \\
\hline $\mathrm{HR}$ & 43 & 31 & 9 & 10 & 4 & 2 & 1 & 0 & 0 & 0 & 0 & 0 & 0 & 0 \\
\hline IT & 23 & 31 & 12 & 17 & 8 & 5 & 3 & 1 & 0 & 0 & 0 & 0 & 0 & 0 \\
\hline $\mathrm{CY}$ & 56 & 23 & 7 & 8 & 3 & 2 & 1 & 0 & 0 & 0 & 0 & 0 & 0 & 0 \\
\hline LV & 18 & 53 & 9 & 11 & 4 & 3 & 2 & 0 & 0 & 0 & 0 & 0 & 0 & 0 \\
\hline LT & 32 & 30 & 12 & 14 & 6 & 4 & 2 & 0 & 0 & 0 & 0 & 0 & 0 & 0 \\
\hline LU & 4 & 6 & 5 & 12 & 12 & 22 & 34 & 5 & 0 & 0 & 0 & 0 & 0 & 0 \\
\hline $\mathrm{HU}$ & 5 & 42 & 13 & 20 & 9 & 5 & 4 & 2 & 0 & 0 & 0 & 0 & 0 & 0 \\
\hline MT & 72 & 18 & 4 & 3 & 1 & 1 & 1 & 0 & 0 & 0 & 0 & 0 & 0 & 0 \\
\hline $\mathrm{NL}$ & 0 & 8 & 7 & 17 & 15 & 24 & 24 & 3 & 0 & 0 & 0 & 0 & 0 & 0 \\
\hline AT & 11 & 14 & 10 & 26 & 21 & 14 & 5 & 0 & 0 & 0 & 0 & 0 & 0 & 0 \\
\hline $\mathrm{PL}$ & 29 & 28 & 13 & 19 & 8 & 3 & 1 & 0 & 0 & 0 & 0 & 0 & 0 & 0 \\
\hline PT & 52 & 18 & 7 & 10 & 5 & 4 & 2 & 1 & 0 & 0 & 0 & 0 & 0 & 0 \\
\hline RO & 65 & 22 & 5 & 4 & 2 & 1 & 1 & 0 & 0 & 0 & 0 & 0 & 0 & 0 \\
\hline SI & 25 & 29 & 15 & 20 & 7 & 3 & 1 & 0 & 0 & 0 & 0 & 0 & 0 & 0 \\
\hline SK & 23 & 26 & 11 & 16 & 7 & 5 & 5 & 3 & 1 & 1 & 1 & 1 & 1 & 1 \\
\hline $\mathrm{FI}$ & 2 & 10 & 10 & 26 & 22 & 18 & 10 & 2 & 0 & 0 & 0 & 0 & 0 & 0 \\
\hline SE & 1 & 23 & 14 & 22 & 13 & 11 & 11 & 4 & 1 & 0 & 0 & 0 & 0 & 0 \\
\hline UK & 1 & 3 & 9 & 20 & 17 & 19 & 21 & 7 & 2 & 1 & 0 & 0 & 0 & 0 \\
\hline EU28 & 27 & 24 & 10 & 16 & 9 & 7 & 5 & 1 & 0 & 0 & 0 & 0 & 0 & 0 \\
\hline
\end{tabular}

Bron: EC (2017b); bewerking Wageningen Economic Research. 
Tabel B3.4 Aandeel van elke ontvangstcategorie in totaal ontvangen toeslagen in de EU-lidstaten, 2015 (\% van totale toeslagen)

\begin{tabular}{|c|c|c|c|c|c|c|c|c|c|c|c|c|c|c|}
\hline & Ontv & gen to & slagen & (€) & & & & & & & & & & \\
\hline & $\begin{array}{l}\text { ڤn } \\
\text { o } \\
\text { v }\end{array}$ & 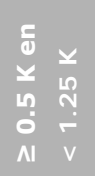 & 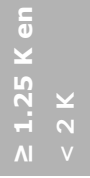 & $\begin{array}{ll}5 & \\
y & Y \\
N & 10 \\
N & V\end{array}$ & 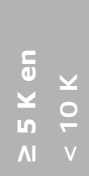 & $\begin{array}{ll}\frac{c}{j} & \\
y & y \\
ㅇ & 0 \\
ㄱ & \\
N & V\end{array}$ & 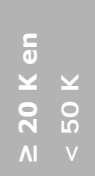 & 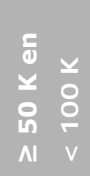 & 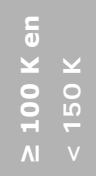 & 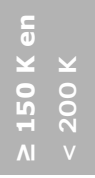 & 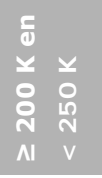 & 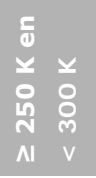 & 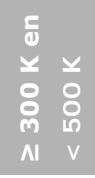 & $\begin{array}{l}\searrow \\
8 \\
i \\
\text { ㄴ }\end{array}$ \\
\hline $\mathrm{BE}$ & 0,0 & 0 & 1 & 4 & 8 & 22 & 45 & 17 & 2 & 1 & 0 & 0 & 0 & 0 \\
\hline BG & 0,3 & 2 & 2 & 6 & 9 & 10 & 13 & 15 & 11 & 8 & 6 & 4 & 7 & 7 \\
\hline$C Z$ & 0,1 & 1 & 1 & 2 & 3 & 5 & 9 & 9 & 7 & 7 & 7 & 6 & 19 & 25 \\
\hline DK & $-0,1$ & 1 & 1 & 3 & 5 & 8 & 22 & 29 & 14 & 7 & 5 & 2 & 3 & 1 \\
\hline $\mathrm{DE}$ & 0,1 & 1 & 1 & 4 & 8 & 18 & 30 & 12 & 5 & 3 & 3 & 3 & 6 & 5 \\
\hline $\mathrm{EE}$ & 1,1 & 4 & 3 & 7 & 7 & 11 & 21 & 17 & 12 & 7 & 3 & 3 & 5 & 1 \\
\hline IE & 0,1 & 1 & 1 & 10 & 19 & 29 & 30 & 8 & 2 & 0 & 0 & 0 & 0 & 0 \\
\hline GR & 2,1 & 7 & 7 & 22 & 23 & 20 & 15 & 3 & 0 & 0 & 0 & 0 & 0 & 0 \\
\hline ES & 1,1 & 3 & 3 & 9 & 11 & 18 & 29 & 13 & 5 & 2 & 1 & 1 & 2 & 2 \\
\hline FR & 0,1 & 0 & 0 & 2 & 4 & 14 & 48 & 25 & 4 & 1 & 0 & 0 & 0 & 1 \\
\hline$H R$ & 6,6 & 13 & 7 & 16 & 16 & 13 & 9 & 4 & 2 & 1 & 1 & 1 & 1 & 9 \\
\hline IT & 1,8 & 6 & 4 & 12 & 13 & 15 & 20 & 13 & 5 & 3 & 2 & 1 & 2 & 2 \\
\hline $\mathrm{CY}$ & 9,4 & 12 & 7 & 17 & 13 & 15 & 17 & 6 & 2 & 1 & 0 & 0 & 0 & 0 \\
\hline LV & 1,9 & 12 & 5 & 11 & 10 & 13 & 19 & 12 & 6 & 4 & 3 & 1 & 1 & 1 \\
\hline LT & 3,4 & 8 & 6 & 15 & 15 & 16 & 18 & 8 & 3 & 2 & 2 & 1 & 2 & 1 \\
\hline LU & 0,1 & 0 & 0 & 2 & 5 & 18 & 55 & 16 & 2 & 1 & 0 & 0 & 0 & 0 \\
\hline $\mathrm{HU}$ & 0,2 & 4 & 3 & 8 & 8 & 11 & 18 & 14 & 6 & 4 & 3 & 4 & 8 & 7 \\
\hline MT & 17,0 & 14 & 6 & 11 & 10 & 14 & 22 & 5 & 0 & 0 & 0 & 0 & 0 & 0 \\
\hline $\mathrm{NL}$ & 0,0 & 0 & 1 & 4 & 7 & 23 & 45 & 14 & 3 & 2 & 0 & 0 & 0 & 0 \\
\hline AT & 0,5 & 2 & 2 & 14 & 24 & 30 & 21 & 3 & 1 & 0 & 0 & 0 & 0 & 0 \\
\hline PL & 3,7 & 9 & 9 & 24 & 22 & 15 & 8 & 4 & 2 & 1 & 1 & 1 & 1 & 0 \\
\hline PT & 6,5 & 4 & 3 & 9 & 10 & 14 & 20 & 16 & 8 & 5 & 2 & 1 & 2 & 1 \\
\hline RO & 10,3 & 10 & 4 & 8 & 8 & 9 & 13 & 11 & 7 & 4 & 3 & 2 & 4 & 7 \\
\hline SI & 2,9 & 10 & 10 & 27 & 20 & 14 & 9 & 2 & 0 & 1 & 0 & 0 & 2 & 3 \\
\hline SK & 0,3 & 1 & 1 & 2 & 2 & 3 & 7 & 8 & 7 & 7 & 7 & 8 & 22 & 25 \\
\hline $\mathrm{FI}$ & 0,0 & 1 & 2 & 9 & 16 & 25 & 31 & 11 & 3 & 1 & 0 & 1 & 0 & 0 \\
\hline SE & 0,0 & 2 & 2 & 6 & 8 & 14 & 32 & 22 & 7 & 3 & 1 & 1 & 1 & 0 \\
\hline UK & 0,0 & 0 & 1 & 3 & 6 & 13 & 31 & 23 & 9 & 5 & 3 & 2 & 2 & 2 \\
\hline EU28 & 1,4 & 3 & 3 & 8 & 11 & 16 & 27 & 15 & 5 & 3 & 2 & 1 & 3 & 3 \\
\hline
\end{tabular}

Bron: EC (2017b); bewerking Wageningen Economic Research. 
Tabel B3.5 Gezinsinkomen uit bedrijf (inclusief directe toeslagen GLB) per gezinsarbeidskracht a) in de EU-lidstaten, 2015 (\% bbp/capita)

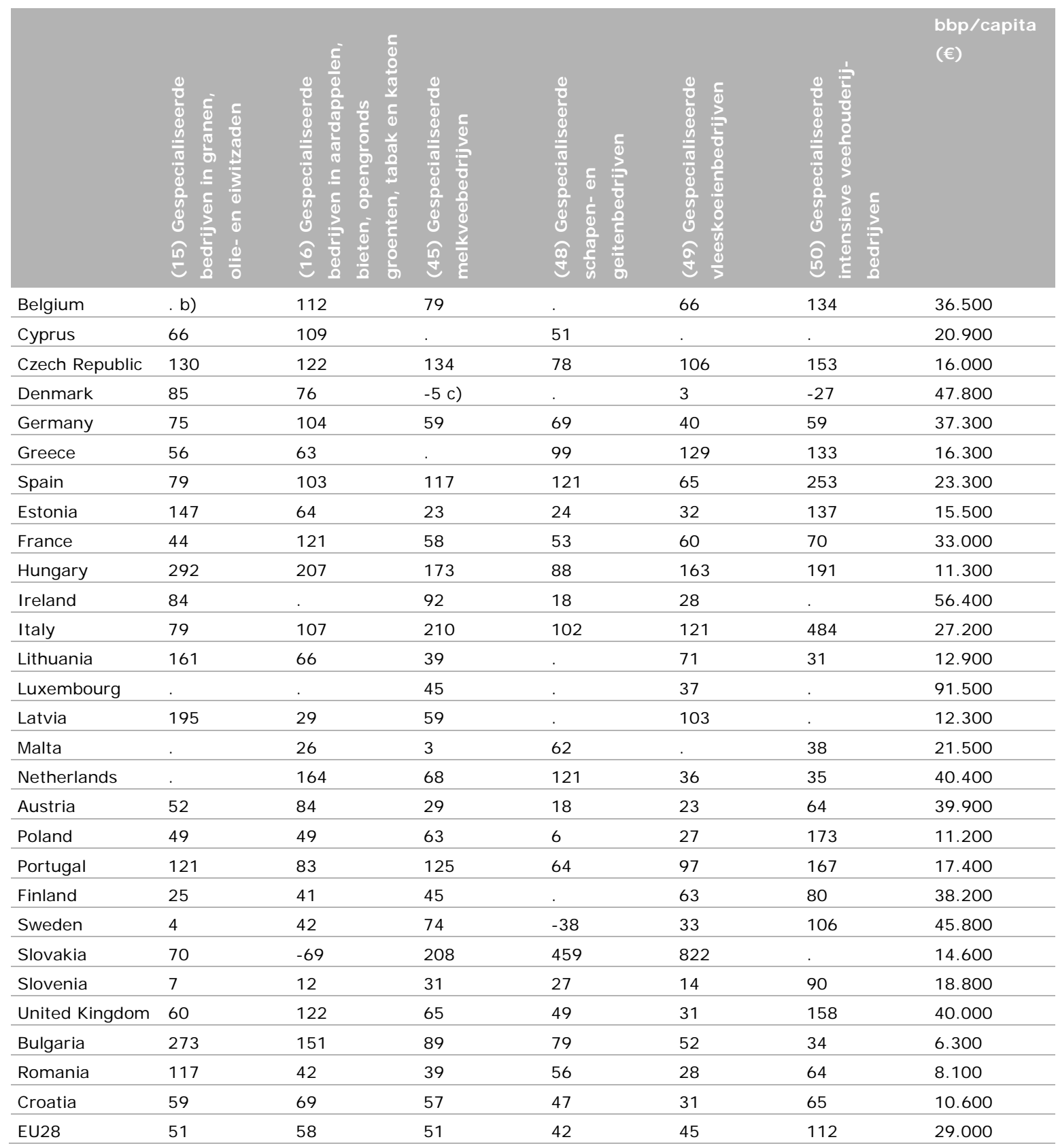

a) FADN-variabele SE430: Family farm income per family labour unit; b) Een punt in een cel geeft aan dat er wegens onvoldoende

waarnemingen geen informatie voor de betreffende groep kan worden gegeven; c) Een negatief landbouwinkomen geeft aan dat de kosten die samenhangen met de landbouwproductie hoger zijn dan de opbrengsten ervan.

Bron: FADN en Eurostat; bewerking Wageningen Economic Research. 
Tabel B3.6 Directe toeslagen GLB per gezinsarbeidskracht in de EU-lidstaten, 2015 (€)

\begin{tabular}{|c|c|c|c|c|c|c|}
\hline & 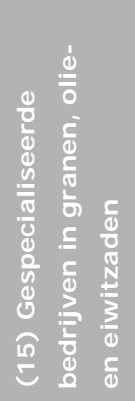 & 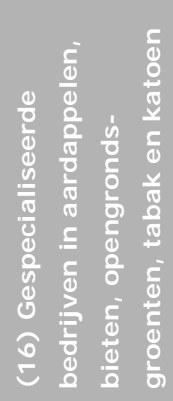 & 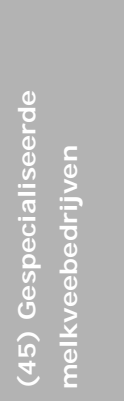 & 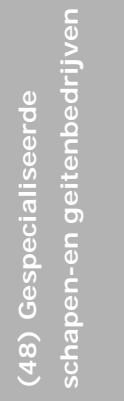 & 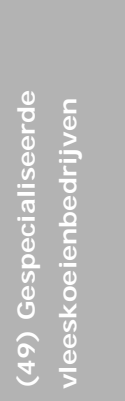 & 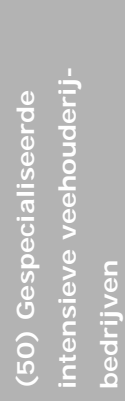 \\
\hline Belgium & . & 21.310 & 12.460 & . & 16.741 & 8.998 \\
\hline Cyprus & 14.806 & 15.692 & . & 6.097 & . & . \\
\hline Greece & 14.824 & 13.126 & . & 8.894 & 20.233 & 1.610 \\
\hline Spain & 17.132 & 13.413 & 11.241 & 11.213 & 12.505 & 4.104 \\
\hline Estonia & 40.227 & 8.920 & . & 9.706 & 22.579 & . \\
\hline France & 27.384 & 26.297 & 19.933 & 26.063 & 31.705 & 11.830 \\
\hline Hungary & 30.467 & 22.445 & 31.266 & 17.347 & 30.053 & 29.136 \\
\hline Ireland & 30.716 & . & 14.830 & 14.263 & 15.417 & . \\
\hline Italy & 14.591 & 11.114 & 11.736 & 10.539 & 14.320 & 5.755 \\
\hline Lithuania & 11.447 & 6.014 & 4.933 & . & 10.271 & . \\
\hline Portugal & 13.239 & 11.085 & 11.391 & 8.775 & 16.199 & 1.365 \\
\hline Finland & 57.270 & 57.032 & 42.156 & . & 79.721 & 56.115 \\
\hline Sweden & 33.413 & 33.602 & 45.910 & . & 33.859 & 40.384 \\
\hline Slovakia & 124.134 & . & 166.123 & 159.061 & 177.887 & . \\
\hline Slovenia & 9.748 & 6.670 & 5.390 & 5.020 & 4.622 & 10.783 \\
\hline United Kingdom & 41.252 & 47.120 & 18.404 & 34.551 & 24.958 & 11.392 \\
\hline Bulgaria & 47.691 & 7.822 & 3.919 & 3.246 & 3.307 & 636 \\
\hline Romania & 6.933 & 1.120 & 542 & 821 & 743 & 1.020 \\
\hline Croatia & 6.437 & 5.802 & 4.387 & 3.505 & 4.184 & 511 \\
\hline EU28 & 18.024 & 11.152 & 10.507 & 8.448 & 15.088 & 9.674 \\
\hline
\end{tabular}

Een punt in een cel geeft aan dat er wegens onvoldoende waarnemingen geen informatie voor de betreffende groep kan worden gegeven.

Bron: FADN; bewerking Wageningen Economic Research. 
Tabel B3.7 Aandeel van de directe toeslagen GLB) in het gezinsinkomen uit bedrijf per gezinsarbeidskracht in de EU-lidstaten, $2015(€)$

\begin{tabular}{|c|c|c|c|c|c|c|}
\hline & 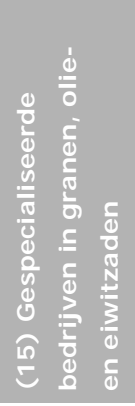 & 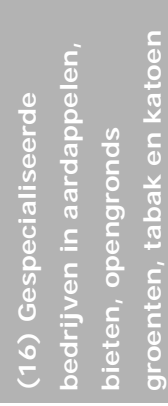 & 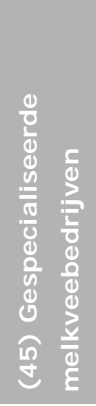 & 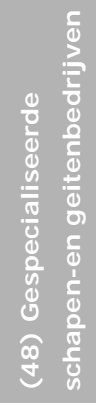 & 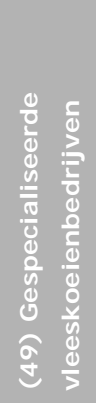 & 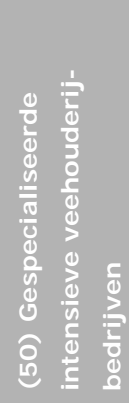 \\
\hline Belgium & . & 52 & 43 & . & 70 & 18 \\
\hline Cyprus & 107 & 69 & . & 57 & . & . \\
\hline Greece & 162 & 128 & & 55 & 96 & 7 \\
\hline Spain & 94 & 56 & 41 & 40 & 82 & 7 \\
\hline Estonia & 177 & 90 & . & 263 & 462 & .. \\
\hline France & 188 & 66 & 104 & 150 & 161 & 51 \\
\hline Hungary & 92 & 96 & 160 & 174 & 164 & 135 \\
\hline Ireland & 65 & & 29 & 141 & 98 & \\
\hline Italy & 68 & 38 & 21 & 38 & 44 & 4 \\
\hline Lithuania & 55 & 71 & 99 & . & 112 & . \\
\hline Portugal & 63 & 77 & 52 & 79 & 96 & 5 \\
\hline Finland & 598 & 366 & 244 & & 329 & 183 \\
\hline Sweden & 1.886 & 173 & 136 & & 224 & 83 \\
\hline Slovakia & 1.220 & . & 547 & 237 & 148 & . \\
\hline Slovenia & 764 & 285 & 93 & 99 & 180 & 64 \\
\hline United Kingdom & 173 & 96 & 71 & 175 & 200 & 18 \\
\hline Bulgaria & 278 & 82 & 70 & 65 & 101 & 30 \\
\hline Romania & 73 & 33 & 17 & 18 & 33 & 20 \\
\hline Croatia & 103 & 79 & 73 & 71 & 127 & 7 \\
\hline EU28 & 123 & 66 & 71 & 70 & 115 & 30 \\
\hline
\end{tabular}

Een punt in een cel geeft aan dat er wegens onvoldoende waarnemingen geen informatie voor de betreffende groep kan worden gegeven.

Bron: FADN; bewerking Wageningen Economic Research. 
Tabel B3.8 Gezinsinkomen uit bedrijf (exclusief directe toeslagen GLB) per gezinsarbeidskracht naar bedrijfstype in de EU-lidstaten, 2015 (\% GDP/capita)

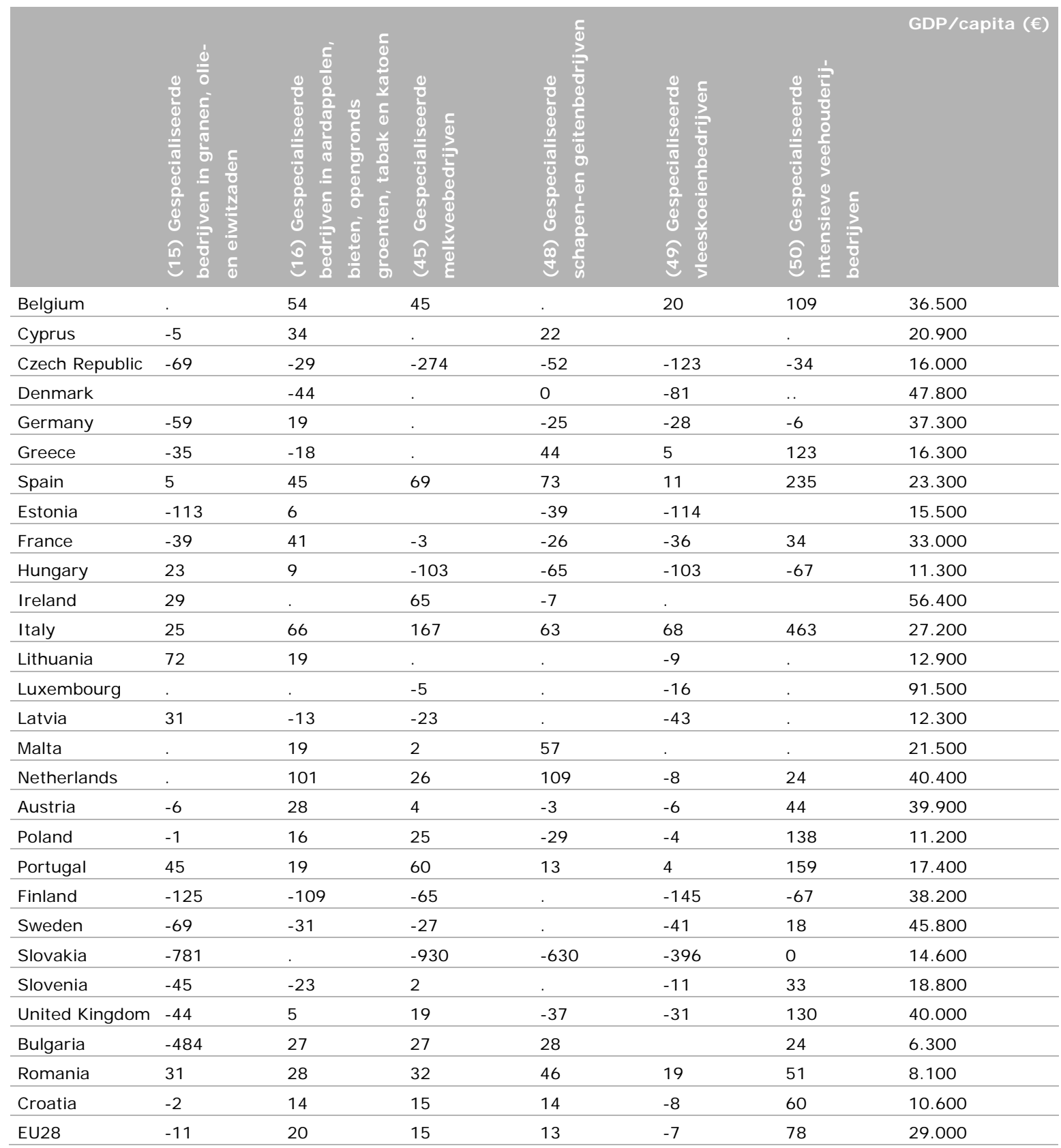

Een punt in een cel geeft aan dat er wegens onvoldoende waarnemingen geen informatie voor de betreffende groep kan worden gegeven.

Een negatief landbouwinkomen geeft aan dat de kosten die samenhangen met de landbouwproductie hoger zijn dan de opbrengsten ervan.

Bron: FADN en Eurostat; bewerking Wageningen Economic Research. 

Wageningen Economic Research Postbus 29703

2502 LS Den Haag

T 0703358330

E communications.ssg@wur.nl

www.wur.nl/economic-research

Wageningen Economic Research RAPPORT

2018-039
De missie van Wageningen University \& Research is 'To explore the potential of nature to improve the quality of life'. Binnen Wageningen University \& Research bundelen Wageningen University en gespecialiseerde onderzoeksinstituten van Stichting Wageningen Research hun krachten om bij te dragen aan de oplossing van belangrijke vragen in het domein van gezonde voeding en leefomgeving. Met ongeveer 30 vestigingen, 5.000 medewerkers en 10.000 studenten behoort Wageningen University \& Research wereldwijd tot de aansprekende kennisinstellingen binnen haar domein. De integrale benadering van de vraagstukken en de samenwerking tussen verschillende disciplines vormen het hart van de unieke Wageningen aanpak.

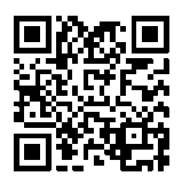





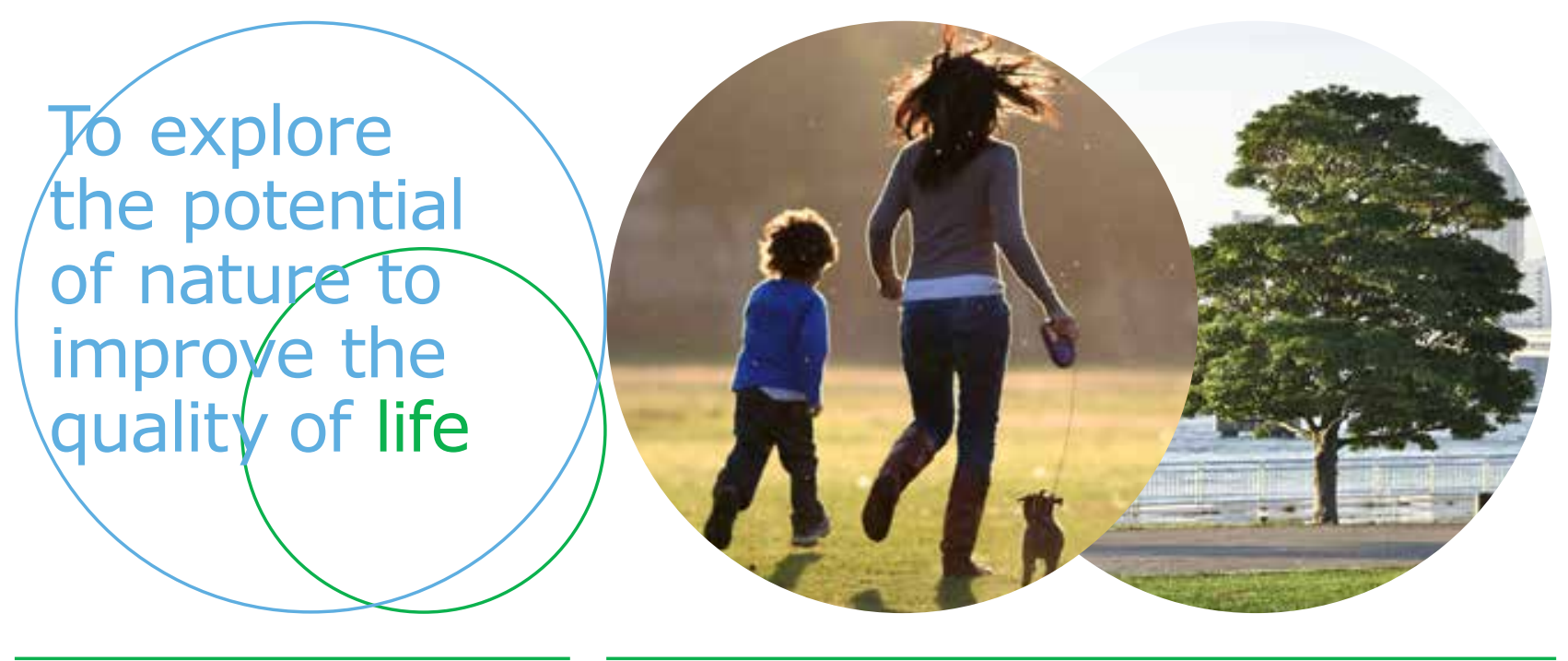

Wageningen Economic Research Postbus 29703

2502 LS Den Haag

E communications.ssg@wur.nl

$T+31(0) 703358330$

www.wur.nl/economic-research

Rapport 2018-039

ISBN 978-94-6343-841-4
De missie van Wageningen University \& Research is 'To explore the potential of nature to improve the quality of life'. Binnen Wageningen University \& Research bundelen Wageningen University en gespecialiseerde onderzoeksinstituten van Stichting Wageningen Research hun krachten om bij te dragen aan de oplossing van belangrijke vragen in het domein van gezonde voeding en leefomgeving. Met ongeveer 30 vestigingen, 5.000 medewerkers en 10.000 studenten behoort Wageningen University \& Research wereldwijd tot de aansprekende kennisinstellingen binnen haar domein. De integrale benadering van de vraagstukken en de samenwerking tussen verschillende disciplines vormen het hart van de unieke Wageningen aanpak. 